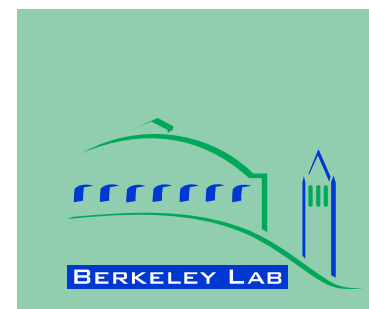

\title{
Energy Efficiency Services Sector: Workforce Size and Expectations for Growth
}

\author{
Charles Goldman, Merrian C. Fuller and Elizabeth Stuart \\ Lawrence Berkeley National Laboratory \\ Jane S. Peters, Marjorie McRae, Nathaniel Albers, \\ Susan Lutzenhiser and Mersiha Spahic \\ Research Into Action, Inc.
}

Environmental Energy Technologies Division

September 2010

The work described in this report was funded by the Department of Energy Office of Energy Efficiency and Renewable Energy, Weatherization and Intergovernmental Program and Office of Electricity Delivery and Energy Reliability, Permitting, Siting and Analysis of the U.S. Department of Energy under Contract No. DE-AC0205CH11231 


\section{Disclaimer}

This document was prepared as an account of work sponsored by the United States Government. While this document is believed to contain correct information, neither the United States Government nor any agency thereof, nor The Regents of the University of California, nor any of their employees, makes any warranty, express or implied, or assumes any legal responsibility for the accuracy, completeness, or usefulness of any information, apparatus, product, or process disclosed, or represents that its use would not infringe privately owned rights. Reference herein to any specific commercial product, process, or service by its trade name, trademark, manufacturer, or otherwise, does not necessarily constitute or imply its endorsement, recommendation, or favoring by the United States Government or any agency thereof, or The Regents of the University of California. The views and opinions of authors expressed herein do not necessarily state or reflect those of the United States Government or any agency thereof, or The Regents of the University of California.

\section{Ernest Orlando Lawrence Berkeley National Laboratory is an equal opportunity employer.}




\title{
Energy Efficiency Services Sector: Workforce Size and Expectations for Growth
}

\author{
Prepared for the \\ U.S. Department of Energy \\ Office of Energy Efficiency and Renewable Energy \\ Principal Authors \\ Charles Goldman, Merrian C. Fuller and Elizabeth Stuart \\ Lawrence Berkeley National Laboratory \\ Jane S. Peters, Marjorie McRae, Nathaniel Albers, \\ Susan Lutzenhiser and Mersiha Spahic \\ Research Into Action, Inc. \\ Ernest Orlando Lawrence Berkeley National Laboratory \\ 1 Cyclotron Road, MS 90R4000 \\ Berkeley CA 94720-8136
}

September 2010

The work described in this report was funded by the Office of Energy Efficiency and Renewable Energy, Weatherization and Intergovernmental Program and Office of Electricity Delivery and Energy Reliability, Permitting, Siting and Analysis of the U.S. Department of Energy under Contract No. DE-AC02$05 \mathrm{CH} 11231$. 


\section{Acknowledgements}

The work described in this report was funded by the Department of Energy Office of Energy Efficiency and Renewable Energy, Weatherization and Intergovernmental Program and Office of Electricity Delivery and Energy Reliability, Permitting, Siting and Analysis of the U.S. Department of Energy under Contract No. DE-AC02-05CH11231.

The authors would like to thank Dan Beckley and Mark Bailey (DOE EERE) and Larry Mansueti (DOE OE) for their support of this project. The authors would also like to thank the members of the Technical Advisory Group for this study for their input and suggestions: Ken Baker (Walmart), Angie Beehler (Walmart), Ralph Cavanagh (NRDC), Fouad Dagher (National Grid), Lara Ettenson, (NRDC), Don Gilligan (NAESCO), Frank Gorke, (Massachusetts DOER), Dian Grueneich (California PUC), Phil Guidice (Massachusetts DOER), Jeff Haberl (Texas A\&M University), Alan Hardcastle (Washington State Dept. of Community, Trade and Economic Development), Kelly Hymes (California PUC), Mary Miller (Edison Electric Institute), Aimee McKane (LBNL), Melissa Lucas (NEEP), Janine Migden-Ostrander (Ohio Consumers Council), Clay Nesler (Johnson Controls), Juliet Pagliaro-Herman (Johnson Controls), Ann Randazzo (Center for Energy Workforce Development), Roland Risser (PG\&E), Gene Rodrigues (SCE), Beth Sachs (Efficiency Vermont), Tim Stout (National Grid), Deb Sundin (Xcel Energy), Tony Usibelli (Washington State Dept. of Community, Trade and Economic Development), Malcolm Verdict (Texas A\&M University), Mark Wallenrod (SCE), and Mike Weedall (BPA).

The authors would also like to thank the following individuals for providing comments and input on a review draft of this study: John Carrese (Centers of Excellence), Ed Londergan, Elizabeth Redman, Robin Walther and Carol Zabin (UC Berkeley).

The authors would also like to thank Steve Selkowitz, Evan Mills, and Neil Elliott (ACEEE) for their useful input to the research. 


\section{Table of Contents}

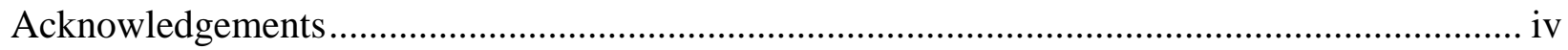

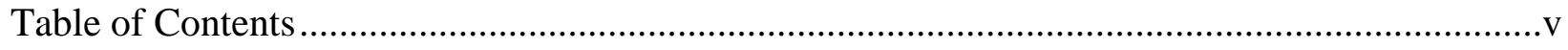

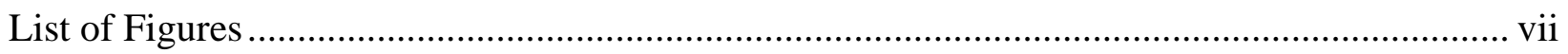

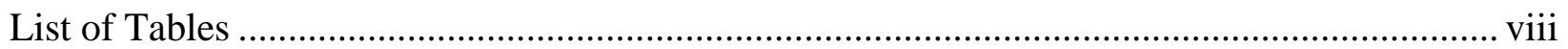

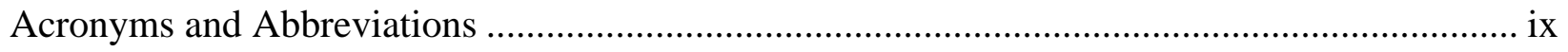

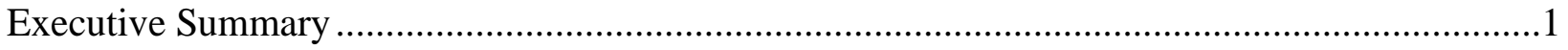

Characterizing the Energy Efficiency Services Sector ......................................................

EESS Workforce Size: Current and Projected...................................................................5

Lesson from Four Case Studies ..............................................................................

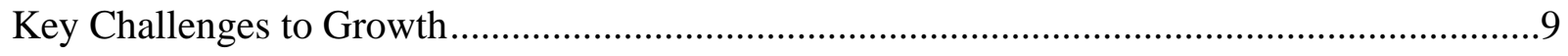

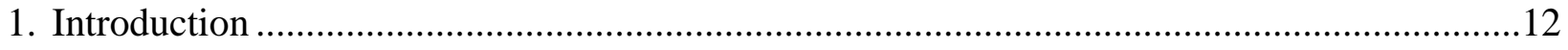

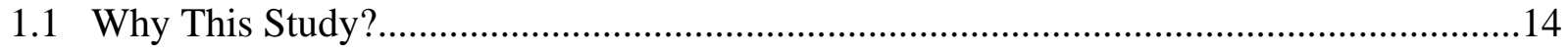

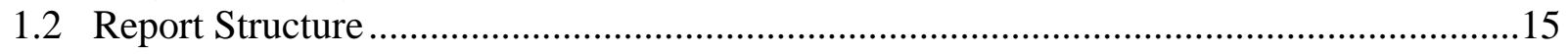

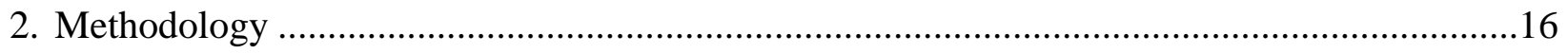

2.1 Literature review: Other workforce studies compared to our approach ..........................16

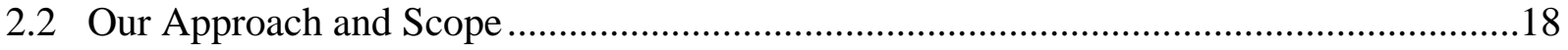

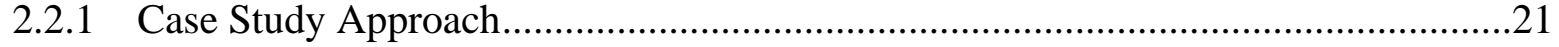

2.3 Methods for Estimating Current and Future Employment .........................................22

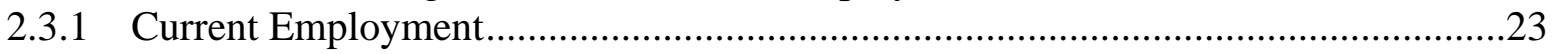

2.3.2 Future Employment ................................................................................25

3. Characterizing the Energy Efficiency Services Sector..................................................27

3.1 Energy Efficiency Market Supply Chain ....................................................................27

3.2 Structure of Energy Efficiency Services Sector and Types of EE Service Providers .......28

3.3 Job Categories and Roles within EESS Organizations .............................................33

3.3.1 Program Administrators and Implementation Contractors ....................................33

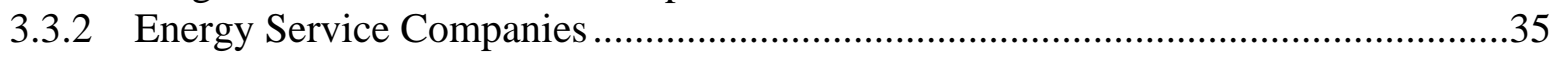

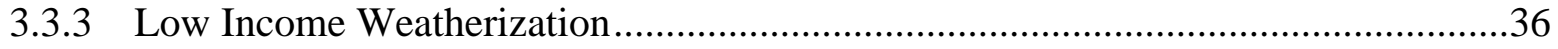

3.3.4 Design, Engineering, and Building and Construction Industries............................37

4. EESS Workforce Size: Current and Projected .................................................................39

4.1 Energy Efficiency Services Sector: National Spending.............................................39

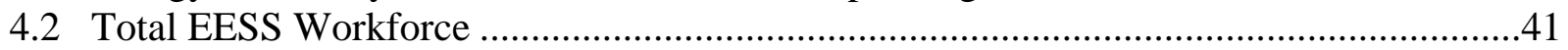

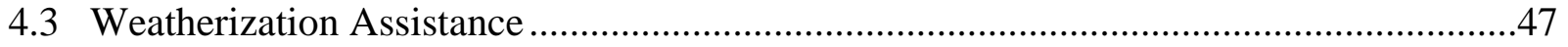

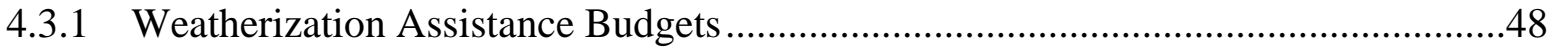

4.3.2 Weatherization Assistance Workforce Estimates .................................................49

4.4 Other ARRA-funded Energy Efficiency Programs ...................................................50

4.4.1 Workforce Assumptions for ARRA Energy Efficiency Programs and Projects .......50 
4.5 Other Federal and State Energy Efficiency R\&D and Program Activities (Independent of ARRA and Weatherization) ..................................................................................................51

4.6 Ratepayer-funded Energy Efficiency Programs ...............................................................51

4.6.1 Building and Construction Industry Workforce supported by Ratepayer-funded

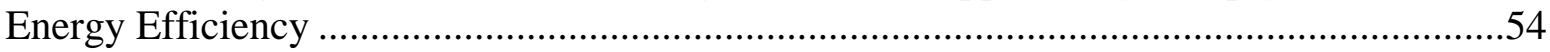

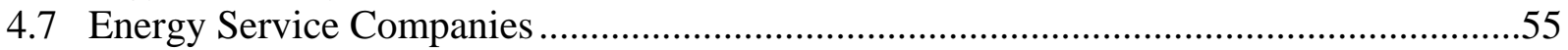

4.7.1 Building and Construction Trades supported by ESCO Projects .............................57

4.8 Insulation Market: Building and Construction Trades conducting Code-Related Activity57

4.9 Direct Workforce Employment and EESS Activity: Summary..........................................57

5. Regional Surveys of Energy Efficiency Employers.............................................................59

5.1 California Employer Survey ………………………….............................................60

5.1.1 Employer Characterization .............................................................................60

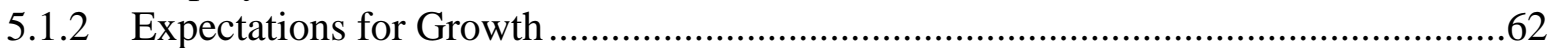

5.1.3 Workforce Development Needs.................................................................................63

5.2 Massachusetts Employer Survey ……………….....................................................64

5.2.1 Employer Characterization ...........................................................................64

5.2.2 Expectations for Growth .................................................................................66

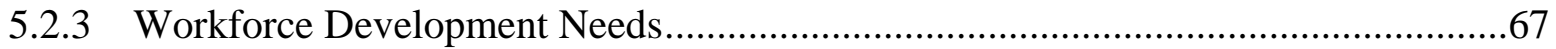

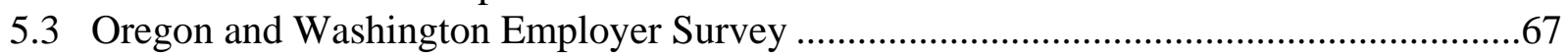

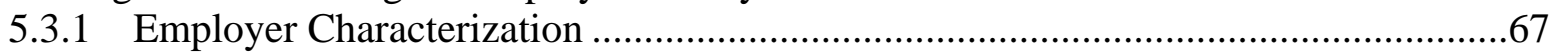

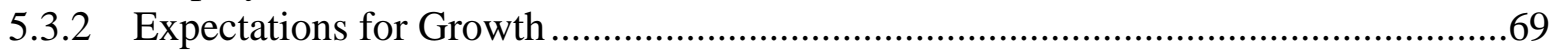

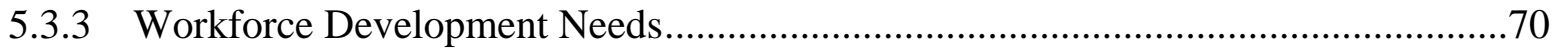

5.4 Connecticut Employer Survey ……………………..................................................

5.4.1 Employer Characterization ...............................................................................

5.5 Comparative Analysis of State or Regional Surveys of Employers on Energy Efficiency

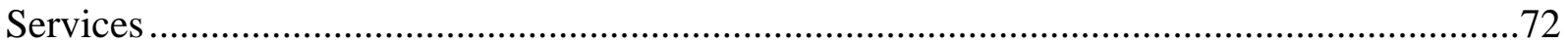

6. Meeting Energy Efficiency Service Workforce Needs ...............................................................75

6.1 Is It Difficult to Hire the Right People? .............................................................................75

6.2 Is There an "Aging Workforce" Issue for the EESS? .......................................................76

6.3 Are There Enough Engineers for an Expanding EESS Workforce?....................................79

6.4 Are there Enough Experienced Managers?..........................................................................83

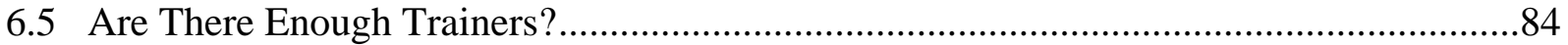

6.6 Near Term Increases in the Energy Efficiency Workforce...................................................85

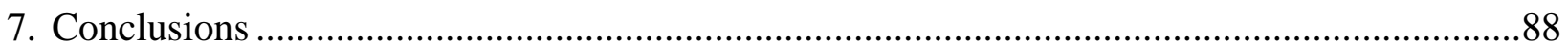

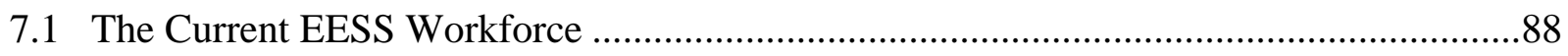

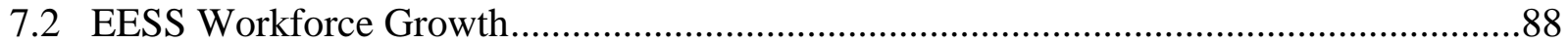

7.3 Preparing for an Expanded EESS Workforce ...................................................................89

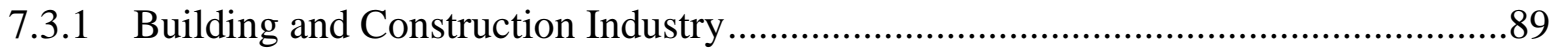

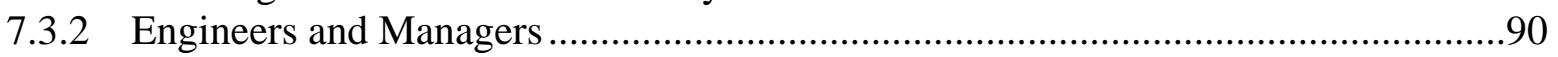

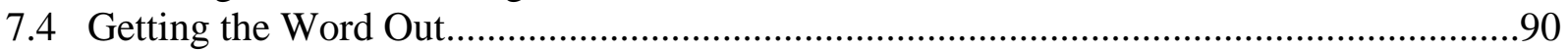

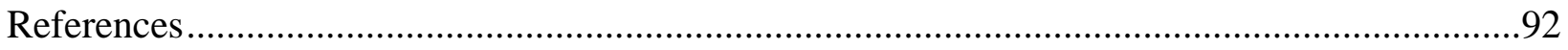




\section{List of Figures}

Figure 1: Energy Efficiency Service Sector and its Relationship to Public Policy and Funding . 13

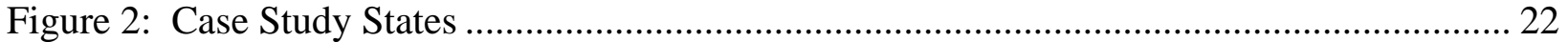

Figure 3: Method for Estimating Current and Future Person-Years of Employment.................. 23

Figure 4: Energy Efficiency Market Value Chain ..................................................................... 27

Figure 5: Commercial-Institutional Energy Efficiency Services Sector................................... 29

Figure 6: Residential Energy Efficiency Services Sector ...................................................... 30

Figure 7: Industrial Energy Efficiency Services Sector....................................................... 31

Figure 8: Distribution of Program Administrators and Program Implementation Contractors

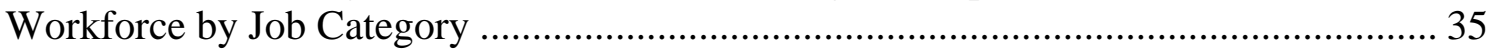

Figure 9: Organizational Functions within ESCO Organizations............................................ 36

Figure 10: Current and Projected Spending in the EESS: High Growth Scenario ...................... 40

Figure 11: Current and Projected Spending in the EESS: Low Growth Scenario....................... 41

Figure 12: Current and Projected Person-Years of Employment in the EESS: High Growth

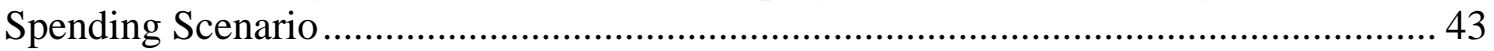

Figure 13: Illustrative Sketch of Number of Individuals Likely Engaged in EESS Activities..... 44

Figure 14: Current and Projected Person-Years of Employment in the EESS: Low Growth

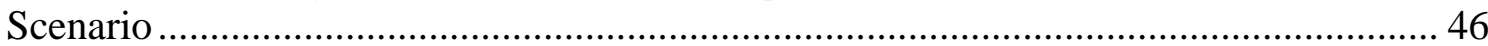

Figure 15: Projected Funding for Low-Income Weatherization Efforts................................... 49

Figure 16: Person-Years of Employment for Ratepayer-Funded Programs (2008): Program

Administration and Implementation and Support Contractors..................................... 53

Figure 17: Program Administrator Funding and Leveraged Market Spending by Customers ..... 55

Figure 18: Segments of Energy Efficiency Value Chain Included in Employer Surveys ............ 59

Figure 19: Industries Identified by California Businesses, Multiple Responses Allowed ........... 61

Figure 20: Distribution of Firm Size Among Energy Efficiency Service Providers in California61

Figure 21: Employer Data for Eight Specific Energy Efficiency Occupations ........................... 62

Figure 22: Job Growth Expectations in 12 Months and 3 Years for California Employers......... 63

Figure 23: Difficulty in Hiring for the Eight Energy Efficiency Occupations ........................... 64

Figure 24: Distribution of Firm Size among Energy Efficiency Service Providers in

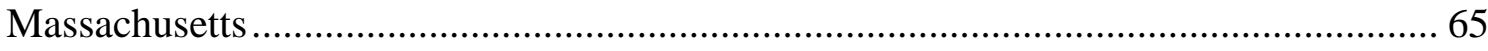

Figure 25: Actual and Projected Growth in "Clean Energy” Revenues for Massachusetts Energy

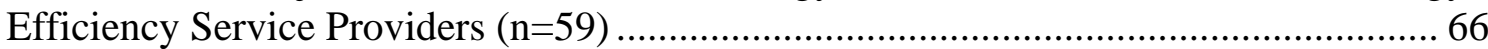

Figure 26: Firm Size in Pacific Northwest for the Top 8 Services Provided ............................. 69

Figure 27: Distribution of Firm Size Among Energy Efficiency Service Providers in the Pacific

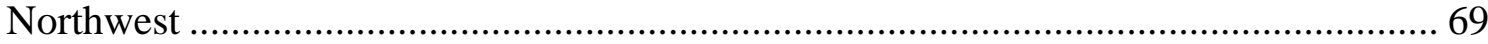

Figure 28: 2007 and Projected Average Annual Revenue Growth over Next Five Years for

Pacific Northwest Energy Efficiency Service Providers............................................. 70

Figure 29: Revenue by Sector Served for Connecticut Energy Efficiency Businesses............... 72

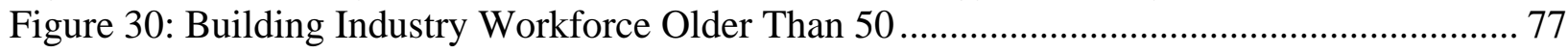

Figure 31: Energy Engineers: Years of Professional Experience .......................................... 78

Figure 32: Preferred Engineers for Program Administrators and Implementation Contractors ... 80

Figure 33: U.S. Defense Spending and Conferred Engineering Degrees ................................ 81

Figure 35: Influence of Energy Efficiency on the Building Industry ...................................... 86 


\section{List of Tables}

Table 1: Other Studies of U.S. Green Jobs Workforce........................................................... 17

Table 2: Sources of Data for Estimating Current Workforce Size ............................................ 24

Table 3: PYE and Spending for Each Sub-Sector ................................................................. 25

Table 4: Sources of Data for Estimating Projections of Future Spending ................................ 25

Table 5: Job Categories: Program Administrators, Program Implementation Contractors and

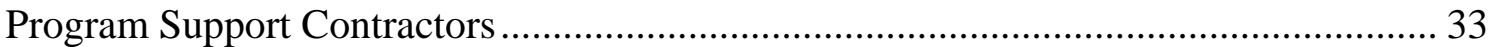

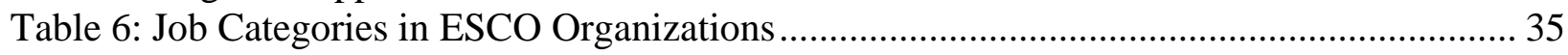

Table 7: Role of engineers in energy efficiency organizations.............................................. 36

Table 8: Job Categories in Low-Income Weatherization Programs ......................................... 37

Table 9: Job Categories in Design, Engineering and Building/Construction Firms that Provide

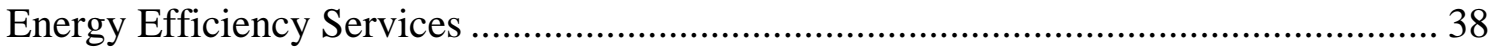

Table 10: Person-Years of Employment in the Energy Efficiency Services Sector: 2008.......... 58

Table 11: Other Clean Jobs Studies Estimates of Person-Years of Employment per Million

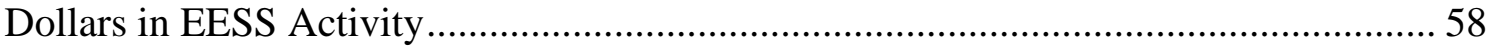

Table 12: Types of Energy Efficiency Services Offered by California Employers .................... 60

Table 13: Types of Energy Efficiency Services Offered by Massachusetts Employers............... 65

Table 14: Types of Energy Efficiency Services Offered by Pacific Northwest Employers that

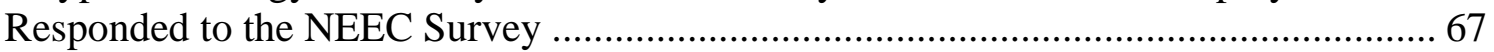

Table 15: Percentage of Jobs by Employee Job Type in Connecticut Energy Efficiency Firms . 71

Table 16: Number of Employees by Engineering Discipline: 2006 ....................................... 80 


\section{Acronyms and Abbreviations}

$\begin{array}{ll}\text { ANSI } & \text { American National Standards Institute } \\ \text { ARRA } & \text { American Recovery and Reinvestment Act } \\ \text { BLS } & \text { Bureau of Labor Statistics } \\ \text { Btu } & \text { British thermal unit } \\ \text { CEE } & \text { Consortium for Energy Efficiency } \\ \text { DHHS } & \text { Department of Health and Human Services } \\ \text { DOE } & \text { Department of Energy } \\ \text { EE } & \text { energy efficiency } \\ \text { EERE } & \text { (DOE Office of) Energy Efficiency and Renewable Energy } \\ \text { EESS } & \text { energy efficiency services sector } \\ \text { EIA } & \text { Energy Information Administration } \\ \text { ESCO } & \text { energy services company } \\ \text { FERC } & \text { Federal Energy Regulatory Commission } \\ \text { FTE } & \text { full-time equivalent } \\ \text { FY } & \text { fiscal year (for federal government, starts October 1) } \\ \text { HVAC } & \text { heating, ventilation, air conditioning } \\ \text { ISO } & \text { International Standards Organization } \\ \text { LBNL } & \text { Lawrence Berkeley National Laboratory } \\ \text { LIHEAP } & \text { Low Income Home Energy Assistance Program } \\ \text { NASCSP } & \text { National Association for State Community Services Programs } \\ \text { PA } & \text { program administrator } \\ \text { PIC } & \text { program implementation contractor } \\ \text { PSC } & \text { program support contractor } \\ \text { PVE } & \text { Petroleum Violation Escrow } \\ \text { PY } & \text { program year } \\ \text { PYE } & \text { person years of employment } \\ \text { R\&D } & \text { research and development } \\ \text { WAP } & \text { Weatherization Assistance Program } \\ & \end{array}$





\section{Executive Summary}

The energy efficiency services sector (EESS) is poised to become an increasingly important part of the U.S. economy. Energy supply and climate change concerns, volatile and increasing energy prices, and a desire for greater energy independence have led many local, state and national leaders to support an increasingly prominent role for energy efficiency (EE) in U.S. energy policy. The national economic recession has also helped to boost the visibility of energy efficiency as part of a strategy to support economic recovery.

One of the paradoxes of energy efficiency is the growing consensus among policymakers as to its importance as a low-cost, environmentally-benign resource juxtaposed with the fact that energy efficiency is not a distinct, well-defined industry that is easy to characterize. The growth in public support for and spending on energy efficiency combined with increased investment by private sector market actors will require a significant expansion of the energy efficiency services sector workforce. Trained personnel will be needed to design, implement, manage and evaluate energy efficiency programs and to design, construct, install, and maintain efficient building systems. Bottlenecks may occur if the EESS workforce is unable to expand at the same pace as the increased demand for energy efficiency services.

Given the growing interest in energy efficiency, there is a concern among policy makers, program administrators, and others that there is an insufficiently trained workforce in place to meet the energy efficiency goals being put in place by local, state, and federal policymakers. To understand the likelihood of a potential workforce gap and appropriate response strategies, one needs to understand the size, composition, and potential for growth of the EESS. We use a bottom-up approach based upon almost 300 interviews with program administrators, education and training providers, regulatory staff and a variety of EESS employers, trade associations and unions; communications with over 50 sector experts; as well as an extensive literature review. We attempt to provide insight into key aspects of the EESS by describing the current job composition, the current workforce size, our projections for growth in spending and employment in the EESS through 2020, and key issues that may limit this growth.

\section{Characterizing the Energy Efficiency Services Sector}

There is a wide range of occupations that might be considered "green jobs." Figure ES-1 shows the market value chain for the EESS and the types of market players and specific occupations. The market supply chain for energy efficiency spans product development, manufacturing, wholesale and retail distribution, deployment (e.g., project design, construction, and evaluation of savings) and operations and maintenance. In this study, we limit our scope primarily to estimating workforce size and needs of that portion of the EESS market supply chain that focuses on deployment and installation of energy efficiency products and services (see Figure ES-1). ${ }^{1}$ Our assessment does not include the manufacturing, wholesale, and retail distribution subsectors, or energy efficiency-focused operations and maintenance performed by facility managers. Our bottom-up approach focuses on those energy efficiency programs and market-

\footnotetext{
${ }^{1}$ In figure ES-1 the abbreviation "EE” stands for “energy efficiency” and the abbreviation "Wx" signifies "weatherization."
} 
driven activities in which market actors and end users regard the energy and dollar savings derived from energy efficiency investments as an important, significant driver of consumer demand. We make this distinction both because the jobs that require the most energy efficiencyspecific training fall into this scope, and also because data are more readily available for this portion of the energy efficiency services sector.

\begin{tabular}{|c|c|c|c|c|c|}
\hline \multirow[b]{2}{*}{$\begin{array}{l}\text { Manufacturing } \\
\& \text { Distribution }\end{array}$} & \multicolumn{4}{|c|}{ Study Scope } & \multirow[b]{2}{*}{$\begin{array}{l}\text { Operations \& } \\
\text { Maintenance }\end{array}$} \\
\hline & $\begin{array}{c}\text { Planning \& } \\
\text { Project } \\
\text { Management }\end{array}$ & $\begin{array}{c}\text { Consulting \& } \\
\text { Auditing }\end{array}$ & $\begin{array}{l}\text { Construction } \\
\& \text { Installation }\end{array}$ & $\begin{array}{l}\text { Evaluation } \\
\text { Monitoring \& } \\
\text { Verification }\end{array}$ & \\
\hline $\begin{array}{l}\text { - Firms designing \& } \\
\text { manufacturing } \mathrm{EE} \\
\text { equipment } \\
\text { - Wholesale } \\
\text { distributors of } \mathrm{EE} \\
\text { equipment } \\
\text { - Retail distributors } \\
\text { of EE equipment }\end{array}$ & $\begin{array}{l}\text { - Program } \\
\text { administrators } \\
\text {-Federal and state } \\
\text { EERE offices } \\
\text { - Implementation } \\
\text { contractors } \\
\text { - Technical } \\
\text { support service } \\
\text { providers } \\
\text { - Energy } \\
\text { management } \\
\text { firms }\end{array}$ & $\begin{array}{l}\text { - Design \& } \\
\text { engineering firms } \\
\text { - Implementation } \\
\text { contractors } \\
\text { - Technical } \\
\text { support service } \\
\text { providers } \\
\text {-ESCOs } \\
\text { - Local Wx } \\
\text { agencies } \\
\text { - Energy } \\
\text { management } \\
\text { firms } \\
\text { - Accreditation } \\
\text { consultants }\end{array}$ & $\begin{array}{l}\text { - Design \& } \\
\text { engineering firms } \\
\text { - Building \& } \\
\text { construction } \\
\text { firms } \\
\text { - Insulation firms } \\
\text { - Technical } \\
\text { support service } \\
\text { providers } \\
\text {-ESCOs } \\
\text { - Local Wx } \\
\text { agencies }\end{array}$ & $\begin{array}{l}\text { - Program } \\
\text { administrators } \\
\text { - Federal and state } \\
\text { EERE offices } \\
\text { - Implementation } \\
\text { contractors } \\
\text { - Technical } \\
\text { support service } \\
\text { providers } \\
\text {-ESCOs } \\
\text { - Energy } \\
\text { management } \\
\text { firms } \\
\text { - Evaluation } \\
\text { consultants }\end{array}$ & $\begin{array}{l}\text { - Building owners \& } \\
\text { managers } \\
\text { - Facilities } \\
\text { operators }\end{array}$ \\
\hline
\end{tabular}

\section{Figure ES-1: Energy efficiency market value chain}

Using data collected from our interviews, we diagram the structure of the EESS for the commercial/institutional, residential, and industrial markets (see Figure ES-2, Figure ES-3 and Figure ES-4). These market characterization diagrams highlight a number of themes about the structure of the energy efficiency services sector. First, for some companies and organizations, energy efficiency is their primary business or activity (e.g., federal and state energy efficiency administrators, program implementation contractors, some ESCOs). However, for many of the firms involved in the EESS, energy efficiency may not be their core business, but comprises a business line or service offering (e.g., design/engineering firms, equipment providers). Second, the darker-colored boxes with solid outlines represent firm types with job categories that also exist outside of the EESS, while the lighter-colored boxes with dotted outlines represent firm types with job categories that are only found within the EESS. Third, the market characterization diagrams utilize a somewhat top-down view of the market from a program administrator's perspective. ${ }^{2}$ Program administrators rely heavily on various types of market actors to design,

\footnotetext{
${ }^{2}$ We take this approach, in part, because historically, a significant amount of energy efficiency investments have been driven by various types of public policies (e.g., federal and state programs). Federal and state EERE administrators include staff at state energy offices. Program administrators oversee ratepayer-funded energy efficiency programs that can be administered by utilities, state agencies, or third-party firms; hence we use the broader term "program administrator" in lieu of "utility."
} 
deliver, and implement high efficiency products and services to facility and building owners. Thus, the bulk of the employment and jobs created from energy efficiency programs typically occur among these market actors. Fourth, many EESS jobs exist elsewhere; often the same services will be performed, such as building engineering or HVAC system installation, but the EESS will ensure that the highest-efficiency options are used. Many "new" EESS jobs will simply substitute for existing jobs, and in some cases it may be the same technicians and trades people updating their offerings through additional training or new suppliers. Many jobs in the EESS are not new jobs, but rather jobs that are evolving to improve the energy efficiency of the product or service provided. To recall the comment by Hendricks (2009) on green jobs: there are created jobs, transformed jobs, and retained jobs. Firm types shown in boxes or bubbles with a dotted outline involve newly created occupational areas of specialization. Firm types shown in the solid boxes comprise occupations that are retained or transformed. A significant expansion of the EESS will necessarily involve the creation of a transformed building and construction industry, which will be at the core of the EESS.

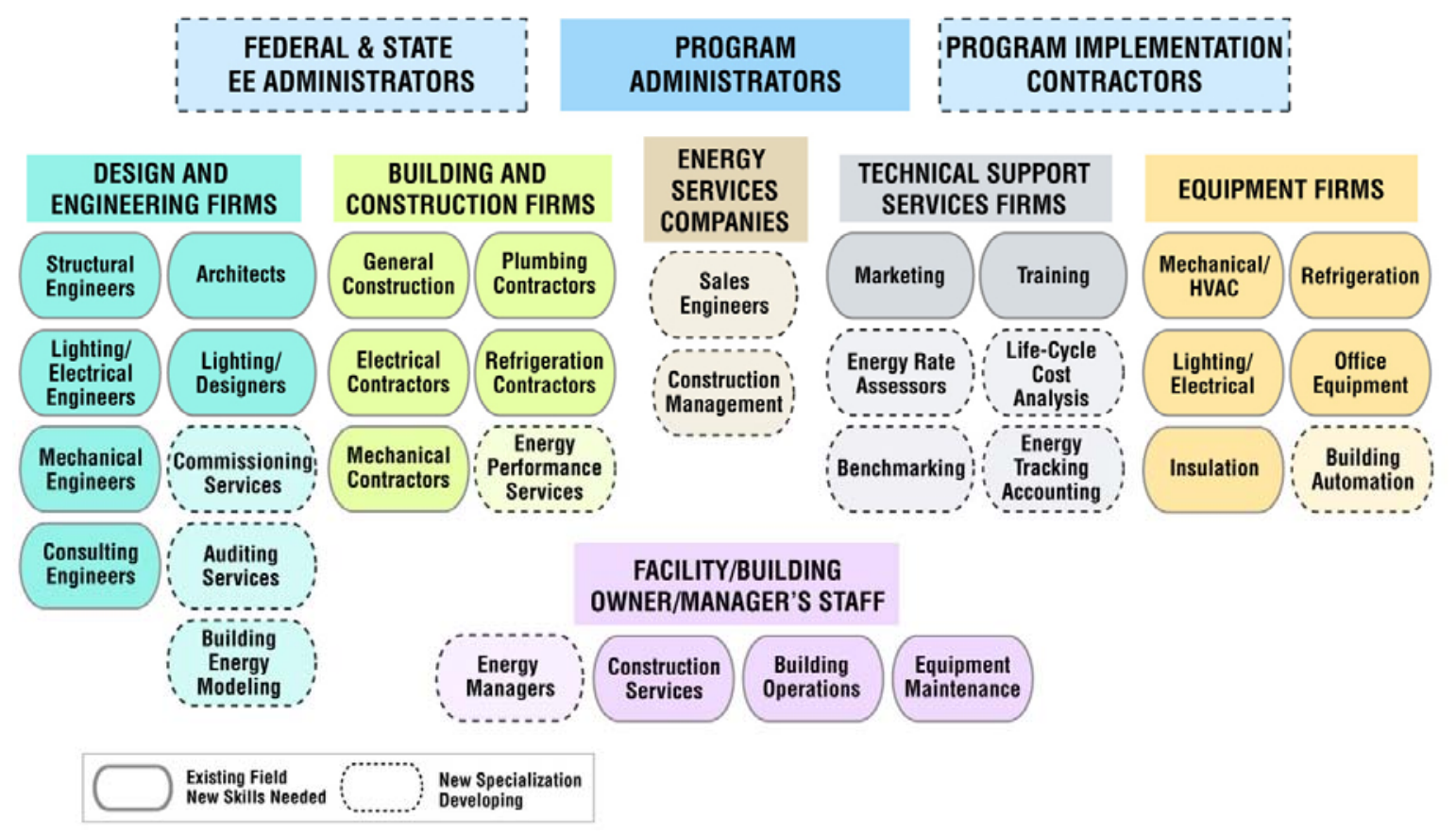

Figure ES-2: The Commercial-Institutional Energy Efficiency Services Sector 


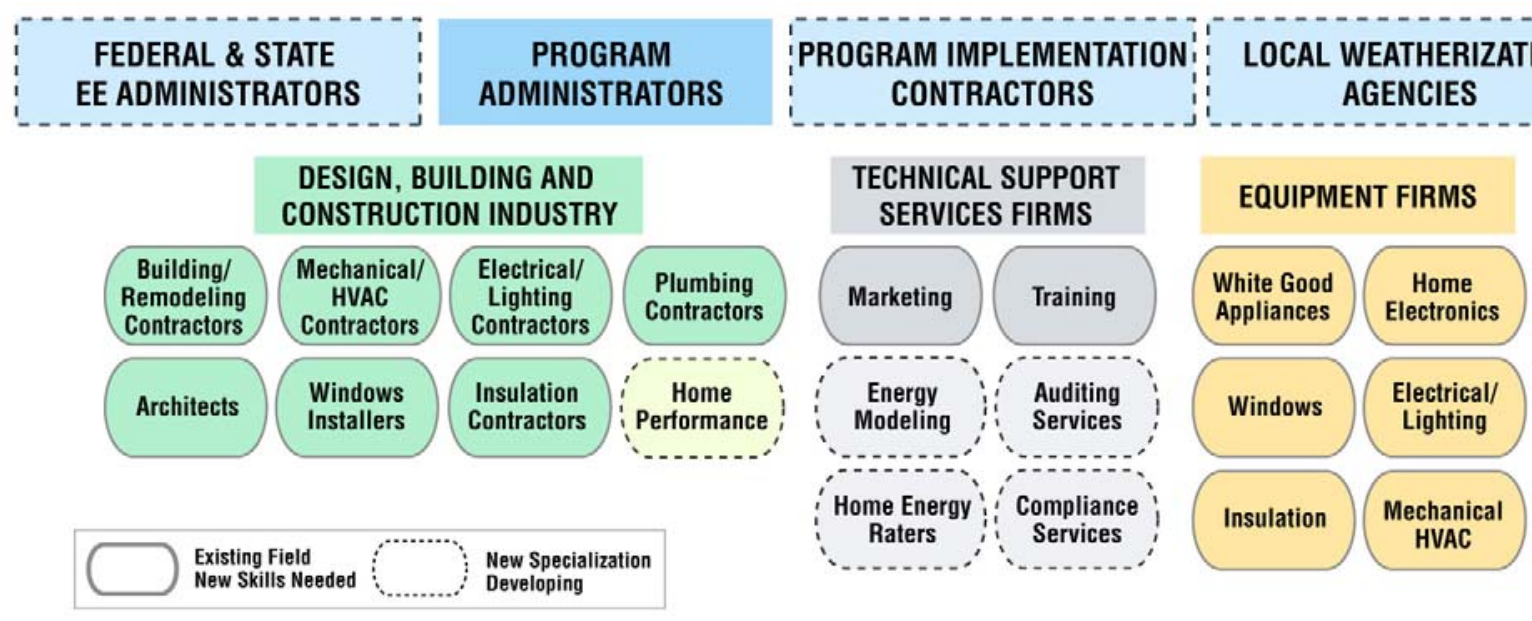

Figure ES-3: The Residential Energy Efficiency Services Sector

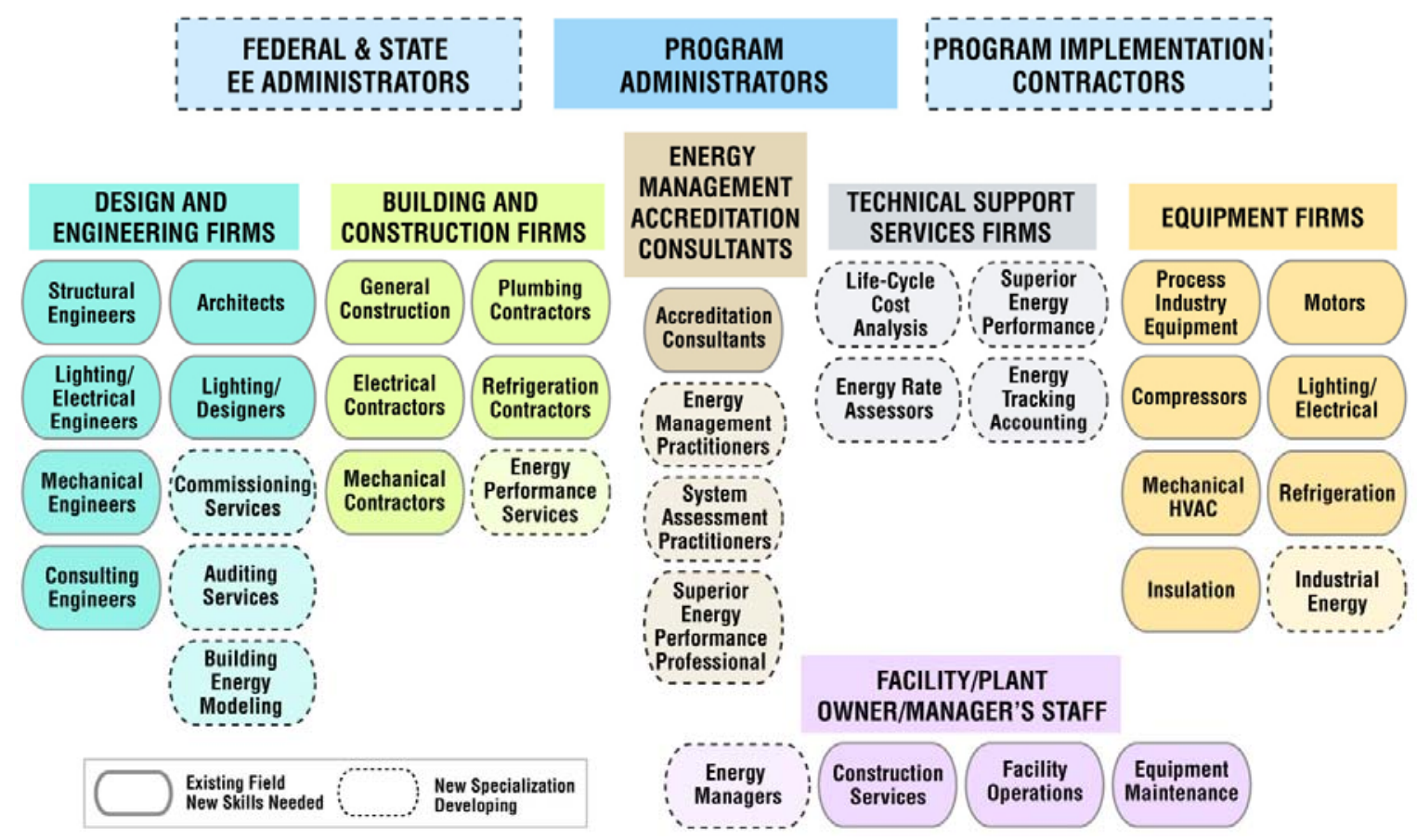

Figure ES-4: The Industrial Energy Efficiency Services Sector

It is clear from the market characterization diagrams that the EESS is a multi-disciplinary sector that addresses the design and construction of homes and buildings, and the installation, use, and maintenance of high-efficiency equipment and technologies in homes, buildings, and industrial processes. The EESS includes engineers, designers, economists, marketers, and trades people. At present, it does not constitute an independent industry, since the activities of the EESS, rather than being new efforts, typically consist of a shift from standard practice to a more energyefficient approach to the design, construction, equipping, and operating of buildings. Hence, this 
is our rationale for using the term "energy efficiency services sector” rather than "energy efficiency industry.”

\section{EESS Workforce Size: Current and Projected}

In 2008, the EESS workforce comprised about 114,000 person-years of employment (PYE) (see Figure ES-5). One PYE equals one person working full time in the EESS for a year. This is different from total number of employees, which can include people who either work part time or just work part time on EESS-specific activities. Many employees in the EESS only work part time or spend only a fraction of their full-time job providing energy efficiency services. We estimate that 380,000 individuals are employed in EESS activities in 2008 in new or transformed jobs (see Figure ES-6), or over three times the estimated EESS workforce in PYE.

We estimate that the building and construction industry workforce engaged in activities that impact the efficiency with which energy is used in buildings (e.g., building construction, home remodeling) was about 4.2 million PYE in 2006 (Bureau of Labor Statistics 2006). ${ }^{3}$ Our estimates of the EESS workforce in the building trades as of 2008 is equivalent to about $2 \%$ of this building and construction industry workforce. ${ }^{4}$

We assume that the future expanded energy efficiency effort will require an EESS with the traditional and emerging activities and job types that we observe today. We develop assumptions about growth in energy efficiency from three primary drivers: growth in federally funded energy efficiency, ratepayer-funded energy efficiency, and market spending on energy efficiency. We posit alternative scenarios that vary in the aggressiveness with which energy efficiency savings are acquired, though given recent events we believe that the high growth scenario is most likely. The study develops predictions for three forecast years: near-term (2010), intermediate term (2015), and long-term (2020).

\footnotetext{
${ }^{3}$ We estimated the size of the building and construction industry most aligned with the EESS by identifying occupational categories (48 categories) in the most aligned industries (NAICS codes 2361, 2362, 2382, 2383, 2389, and 5413) and tallied how many PYE they represent. The Bureau of Labor Statistics reported data for 2006 and a forecast for 2016, from which we calculated an average growth rate to 2020.

${ }^{4}$ Our analysis includes estimated PYE of both professionals and trades people employed in the EESS. However we can approximate the trades' employment by considering just employment in insulation industry and building and construction industry activity induced by ratepayer-funded energy efficiency programs and ESCO spending.
} 


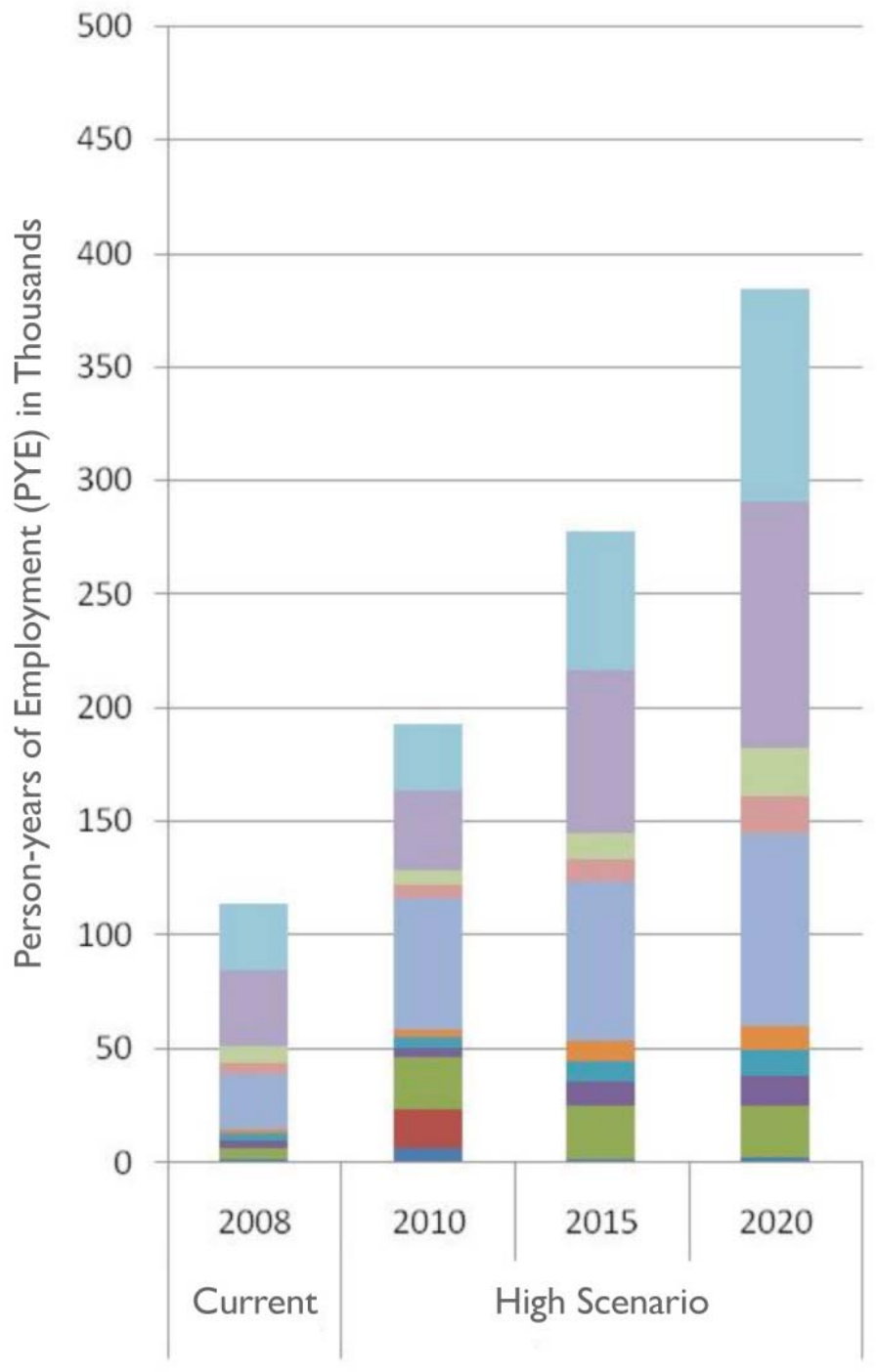

Mechanical Insulation

Building Envelope Insulation

Building and Construction Industry Induced by ESCO Activity ESCO Staff

Building and Construction Industry Induced by PA Spending

Program Support Contractors

Ratepayerfunded

Program Implementation Programs

\section{Figure ES-5: Current and Projected EESS Person-years of Employment - High Growth Spending Scenario}

Program Administrators (PA)

Weatherization Agencies and Contractors

EE Staff Funded by ARRA

Programs

Federal \& State EE

Administrator Employees

As summarized in Figure ES-5, ratepayer-funded energy efficiency efforts currently constitute about 30\% of estimated EESS person-years. This employment includes the staffs of program administrators, the program implementation contractors, and program support contractors as well as the building and construction professionals and trades people that design and install energy efficiency projects that are developed through ratepayer funded programs. ${ }^{5}$ ESCO efforts constitute about $10 \%$ of the total person-years, including ESCO staff and the contractors they hire among the building and construction industry. The weatherization assistance efforts of the

\footnotetext{
${ }^{5}$ Program administrators are utility, governmental, nonprofit or contracted third-party organizations that design and manage programs that facilitate the implementation of energy-efficient solutions. Program implementation contractors are hired by program administrators to design and implement energy efficiency programs. Program support contractors may design, manage, and evaluate energy efficiency programs, provide business management consulting, and in some cases install and/or inspect energy efficient projects.
} 
federal and state governments constitute about 5\% of the total EESS person-years.. Finally, the professionals and trades people responsible for building envelope insulation and for mechanical insulation each comprise more than $25 \%$ of the 2008 EESS person-years of employment.

For our high growth scenarios to 2020, we find that the EESS may grow to just under 400,000 PYE, which may include as many as 1.3 million individuals (see Figure ES-6). This is a fourfold increase in jobs between 2008 and 2020; our low growth scenario predicts a two-fold increase over the same period.

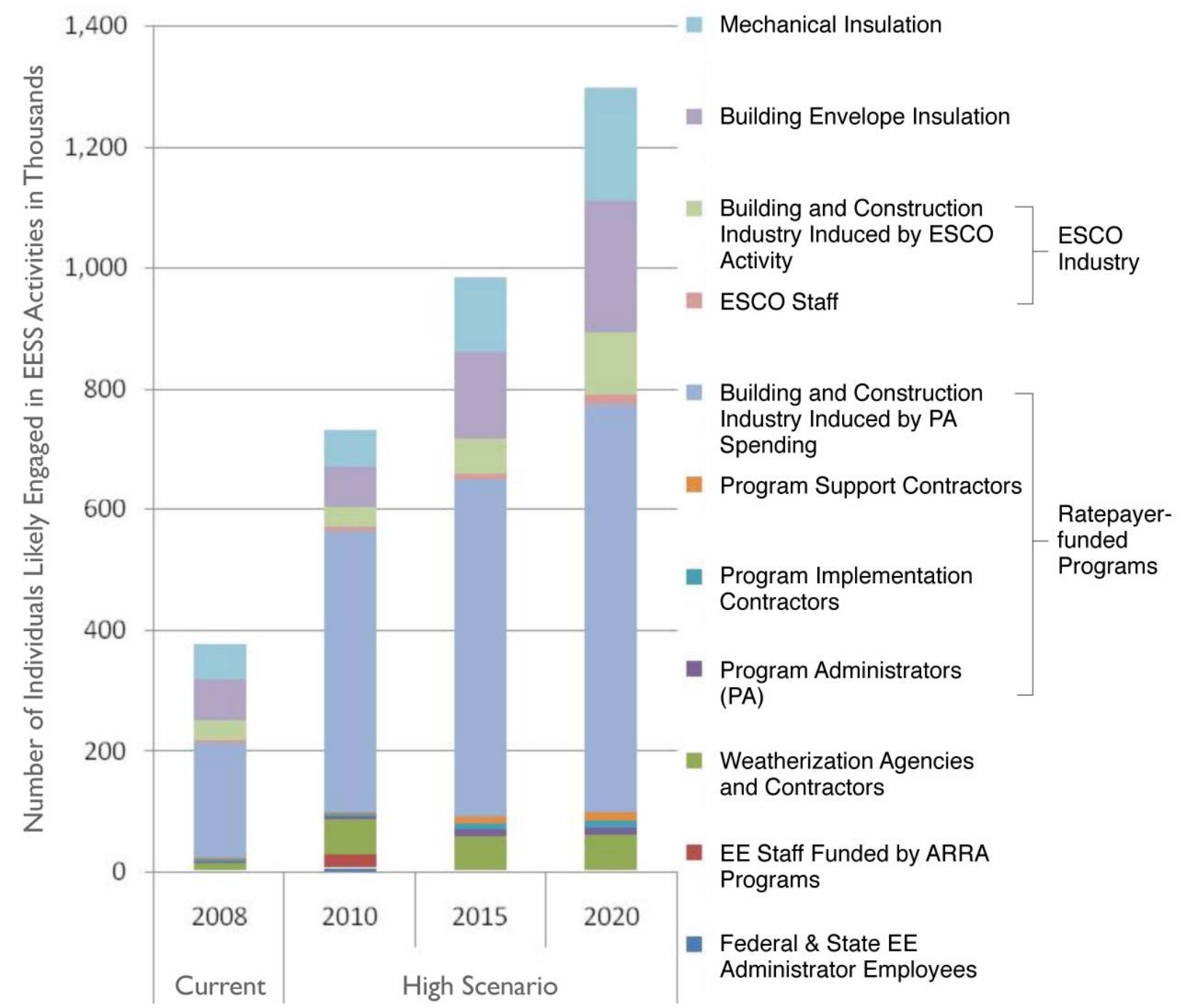

Figure ES-6: Illustrative Sketch of Number of Individuals Likely Engaged in EESS Activities

Table ES-1 summarizes our findings on estimated person-years of employment per \$1 million dollars (PYE/\$1M) of spending on EESS activity. Note that the PYE values in this study capture only direct employment in the activities of designing and installing efficiency measures and do not capture jobs that indirectly result from EESS activity. 
We find that 6.3 jobs per $\$ 1$ million of investment in EESS activity are created on average with a range of 2.5 jobs created per million dollars in ESCO activity to 8.9 jobs in weatherization and insulation activity. Our average estimate of person years of employment (6.3) falls between that of the American Solar Energy Society (ASES) (Bedzek 2007) - 3.8 jobs per million dollars investment - and that of the American Council for an Energy Efficient Economy (ACEEE 2009) - 9.8 jobs per million dollars of investment (see Table 11).

Table ES-1: Person-Years of Employment in the Energy Efficiency Services Sector: 2008

\begin{tabular}{||l|c|c|c||}
\hline \multicolumn{1}{|c|}{ Activity } & $\begin{array}{c}\mathbf{2 0 0 8} \\
\text { Spending } \\
\text { (in \$M) }\end{array}$ & $\begin{array}{c}\text { 2008 Person-Years of } \\
\text { Employment }\end{array}$ & $\begin{array}{c}\text { Person-Years of } \\
\text { Employment per } \\
\mathbf{\$ 1 M}\end{array}$ \\
\hline $\begin{array}{l}\text { Weatherization assistance (excluding program } \\
\text { administrator assistance) }\end{array}$ & $\$ 528$ & 4,700 & 8.9 \\
\hline $\begin{array}{l}\text { Government (federal and state) } \\
\begin{array}{l}\text { Program administrators, program implementation } \\
\text { contractors, program support contractors, and } \\
\text { associated building and construction industry }\end{array}\end{array}$ & $\$ 243$ & 1,600 & 6.5 \\
\hline $\begin{array}{l}\text { ESCOs and associated building and construction } \\
\text { industry }\end{array}$ & $\$ 4,957$ & 32,600 & 6.2 \\
\hline $\begin{array}{l}\text { Building and construction industry influenced by } \\
\text { codes and standards (insulation) }\end{array}$ & $\$ 7,091$ & 12,200 & 2.5 \\
\hline Total & $\mathbf{\$ 1 8 , 0 4 3}$ & $\mathbf{1 1 4 , 0 0 0}$ & 8.9 \\
\hline
\end{tabular}

\section{Lesson from Four Case Studies}

In addition to our own interviews, we analyzed four recent studies that surveyed employers offering various types of energy efficiency services in California, Massachusetts, the Pacific Northwest, and Connecticut. We find the following trends across these studies:

- Most firms providing energy efficiency services are extremely small (often under 10 people), with a few very large firms. For example, well over $75 \%$ of firms in California, the Pacific Northwest and Massachusetts have 100 or fewer employees per firm, and at least 34\% of each have 10 or fewer employees. These employers tend to include a large number of small consulting firms and startups, and a few very large engineering firms and ESCOs.

- These firms' operations appear to frequently span more than one state. For example, when asked directly how many of their employees are based in-state, the average per firm in Massachusetts is 27 employees (21\% of the firms' average total employees). Most of the multi-state firms are the large engineering, consulting and energy service companies. The smaller firms (e.g., home performance, HVAC technicians) generally operate locally. 
- Expectations for growth are high, perhaps particularly in the energy efficiency portion of a firm's business. In Massachusetts, most employers expected greater than $10 \%$ growth in revenue and an average 9\% increase in employees in the next 12 months. In the Pacific Northwest, most employers expect revenues to grow at an annual rate of 5$7 \%$ over the next 5 years. In California, employers expected a 20\% growth in energy efficiency-specific jobs in the next 12 months, versus $2 \%$ growth for all job categories.

- "Premium" energy efficiency jobs are likely only a fraction of the total employees in many firms. The eight energy efficiency-specific jobs identified at California firms make up only $28 \%$ of the total jobs at these firms. ${ }^{6}$ Energy efficiency firms comprise a variety of job types, and in order to inform the estimates of the overall number of energy efficiency-specific jobs and the need for training programs in these specific occupations, it is important to recognize the fact that not all jobs at these firms require energy efficiency-specific skills.

- Additional energy efficiency training is needed. In California, $56 \%$ to $73 \%$ of employers (depending on the job category) have "great" or "some" difficulty in hiring. In the Northwest, $70 \%$ of employers "could not or sometimes could not find qualified applicants.” In Massachusetts, 24\% of employers were not able to fill positions with qualified candidates.

The survey results highlight the makeup and size of the EESS in various states and regions and provide insight into the types of training and support that are valued by employers looking to provide energy efficiency services.

\section{Key Challenges to Growth}

Our interviews revealed a number of key challenges to growth for the EESS:

- Difficulty hiring into the EESS for any position other than entry level. According to our respondents, it often took two to three months to fill entry-level positions in the EESS. Management positions requiring at least 10 years experience and positions requiring engineering experience with high-efficiency technologies are the most difficult positions to fill; survey respondents noted that many position take three to five months to fill but that it can take up to 15 months to hire an engineer with managerial skills and energy efficiency experience. One company gave the example of receiving 80 applications for a senior level position only to find that only five applicants could pass

\footnotetext{
${ }^{6}$ The California survey, conducted by the California Community College Centers of Excellence, focused on eight energy efficiency-specific occupations which were identified as both high growth and in alignment with community college educational core competencies. The eight occupations are: 1) energy auditor; 2) building performance/retrofitting specialist; 3) energy regulation specialist; 4) project manager for construction or design work; 5) HVAC technician or installer; 6) resource conservation or energy efficiency manager; 7) building controls system technician; and, 8) building operator or engineer.
} 
the initial screening. Another company noted that they were planning to take several years to find a suitable candidate to take a senior position leading their energy efficiency group. In contrast, building and construction industry contractors do not hire for energy efficiency skills, as most training is done on the job; they report relative ease in hiring from a variety of sources. However, union contractors and labor union respondents reported some difficulty recruiting qualified applicants into apprenticeship programs. They have many applicants, but a much smaller number who can pass the basic skills and drug screening tests. In a similar vein, several contractor association respondents expressed dismay over a lack of interest in jobs that are physically demanding.

- The challenge of finding managers with energy efficiency experience is a significant issue. The bi-modal age distribution that is observed in many firms suggests that in the next few years there could be a problem having sufficient staff to train and manage the new entrants. One program implementation contractor stated that it is "almost impossible to find someone with energy efficiency program management experience.” People with this knowledge and experience are highly valued by the industry. They are also vital mentors for the next generation of managers in the EESS. This issue may become increasingly important in the future as the EESS workforce demand increases because there are few schools and training centers that offer curricula focused on energy efficiency; on-the-job mentoring currently fulfills EESS training needs.

- Engineers with the appropriate skills are difficult to find. Program administrators, program implementation contractors, and ESCOs who work with commercial and industrial customers indicate that engineering talent is difficult to find. Survey respondents reported that engineers with efficiency knowledge or experience are relatively nonexistent. To be effective, EESS engineers need training in fluid and thermodynamics, knowledge of building energy systems, an interest in optimizing the performance of existing HVAC or refrigeration or industrial process systems, and good communication skills for working with customers. The most likely near-term source for new EESS engineers is to transition engineers from other fields into energy efficiency. In addition, recognizing energy engineering as an engineering discipline will be helpful to recruiting and tracking engineers with energy expertise. A few of our survey respondents also noted difficulty competing for engineers with large international firms or high tech computing and aerospace companies that offer higher salaries and perks such as international travel.

- Retirement is an issue for the building and construction industry. Retirement is not currently a concern for program administrators or program implementation contractors. However, the building and construction industry is facing substantial changes in the workforce due to retirements between 2015 and 2020. Builders/remodelers and mechanical and electrical trades people had the largest share of workers nearing retirement (38\% to $44 \%$ are older than 50 ).

- The building and construction industry is largely unaware that the EESS is expanding. Program administrators and program implementation contractors have fairly 
clear expectations for growth of energy efficiency services, and the likely effect on their workforce needs. For example, in response to a question which asked respondents to estimate the size of their organizations' workforce involved in energy efficiency by 2010, we found that in aggregate, program administrators estimated that their staff will grow about $19 \%$ by 2010 and that program implementation contractors expected that their staff would increase by about $64 \%$. In contrast, less than $50 \%$ of those in design, engineering, and building and construction industry associations could even estimate the percent of the current workforce affected by energy efficiency. Of those that could, the design and engineering associations perceive energy efficiency to have a dominant or moderate influence on their current activities, while other building and construction association respondents see only a moderate or limited level of influence on their activities. National representatives of building and construction industry associations need to educate their state and local organizations on the policy and market drivers that are leading to significant increases in energy efficiency spending so that they can inform their members of the need to develop the necessary skills to provide energy efficiency-related services to meet the coming demand. 


\section{Introduction}

The energy efficiency services sector (EESS) is poised to become an increasingly important sector of the U.S. economy. Climate change and energy supply concerns, volatile and increasing energy prices, and a desire for greater energy independence have led many state and national leaders to support an increasingly prominent role for energy efficiency in U.S. energy policy. The national economic recession has also helped to boost the visibility of energy efficiency, as part of a strategy to support economic recovery.

The evolution and growth of the EESS has been heavily influenced by federal and state legislative, regulatory, and policy initiatives over the last 30 years (see sidebar on Timeline: Energy Efficiency Policy Milestones). Market barriers and failures that cause consumers and businesses to under-invest in energy efficiency has been a key rationale for government action and public policies that attempt to spur energy efficiency efforts among consumers and businesses. As Figure 1 shows, state policies that support ratepayer-funded energy efficiency programs, ${ }^{7}$ federal and state low-income weatherization efforts, enabling legislation that facilitates performance contracting by ESCOs, and building codes and standards have been major contributors to the increase in energy efficiency investments (e.g., the building and mechanical insulation industry)

One of the paradoxes of energy efficiency is the growing consensus among policymakers as to its importance as a low-cost, environmentally benign resource juxtaposed with the fact that energy efficiency is not a distinct, well-defined industry that is easy to characterize. Erhardt-Martinez and Laitner (2008) identified the challenges for those seeking to assess the energy efficiency services market:

\section{Energy efficiency is a means of using less} energy to provide the same (or greater) level

\footnotetext{
${ }^{7}$ State regulatory commissions in $\sim 32-35$ states have authorized expenditure of ratepayer funds to develop energy efficiency programs that reduce electricity and natural gas usage in customer facilities. Utilities typically collect these funds either as a separate charge on customers' bills (e.g., public purpose or benefit charge) or costs are included in rates; programs are administered by utilities, state agencies or third-party firms (see Barbose et al. 2009).
} 
of energy services... Efficiency gains are often embedded within existing technologies and practices and tend to be difficult to measure. In business and industry, efforts to increase energy efficiency or energy productivity can be ingrained in everyday operations and management practices, design decisions, and long-term capital investments. For individuals and households, investments in efficiency include choices in appliances, consumer electronics, and home improvements. Gains in energy efficiency are often bundled with other benefits of new technologies. How do we identify and measure all of the areas in which efficiency gains are made when they are so fragmented throughout industries, businesses and households?

Efficiency resources are disbursed throughout a wide variety of products, technologies, and systems that require replacement or retrofit to achieve higher levels of efficiency.

Similarly, the Northwest Energy Efficiency Task Force (2009a) noted that, "There is difficulty in identifying the true workforce and jobs data for the energy efficiency industry. Employment in energy efficiency is refracted across utilities, federal and state programs, manufacturing, construction, and other disparate job classifications.”

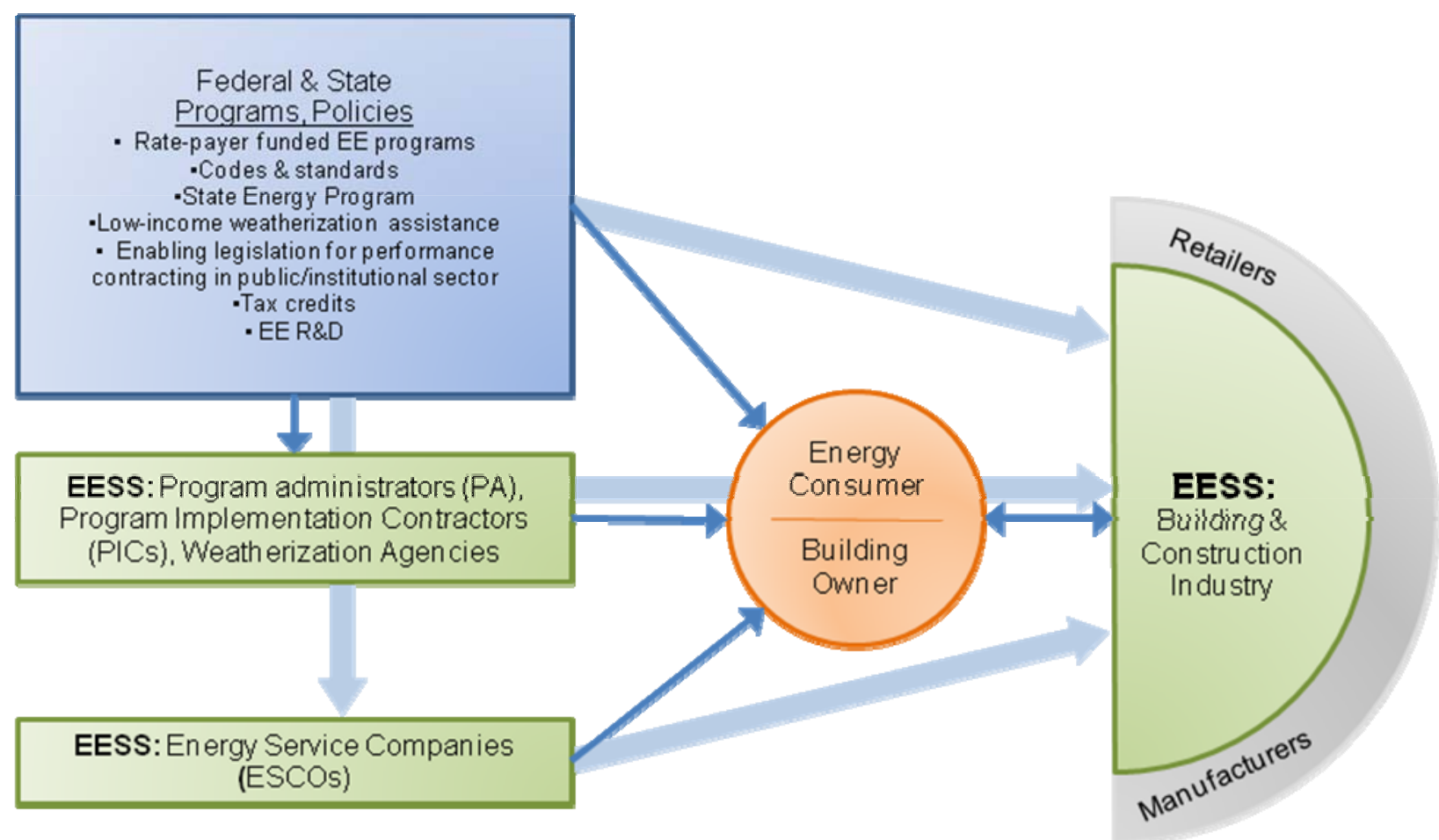

Figure 1: Energy Efficiency Service Sector and its Relationship to Public Policy and Funding 


\subsection{Why This Study?}

The growth in public support for and spending on energy efficiency combined with increased investment by private sector market actors will require a significant expansion of the energy efficiency services sector workforce. Trained personnel will be needed to design, implement, and manage energy efficiency programs and to design, construct, install, and maintain efficient building systems. Bottlenecks may occur if the EESS workforce is unable to expand at the same pace as the increased demand for energy efficiency services.

To assess the likelihood of bottlenecks in providing energy efficiency services, one needs to understand the size and composition of the existing EESS, as well as potential for growth in the future. We attempt to provide insight on these issues by describing the composition and types of jobs in the EESS, estimating the size of the current workforce, projecting growth in the EESS through 2020, and identifying key issues that may limit future growth. A companion report focuses on education and training activities and needs in the EESS (Goldman et al. 2010).

The need to understand the EESS is heightened by the call for "green job" creation by politicians and other leaders (Garfield and Angelides 2008). The Center for American Progress defines "green jobs" as follows:

Green jobs represent new demand for labor that results from investments in transitioning our economy away from carbon-intensive energy, minimizing degradation of our natural resources, maximizing the efficient use of our natural capital, and protecting humans and the planet from pollution and waste. These green jobs include new jobs that will be created, imperiled jobs that will be saved through new investment, and critically, traditional jobs that will be transformed with new skills and new applications of existing skills. (Hendricks 2009).

The EESS represents one part of the "green jobs” market (Dafoe 2007; Apollo Alliance 2007) and covers a range of occupational categories that already exist, as well as new job categories (California Employment Development Green Jobs Website 2009; Oregon Employment Department 2008). However, someone seeking to identify a job in the EESS through occupational research would find it difficult to do. Consider that a search on renewable energy in the U.S. Department of Labor (DOL) Occupational Handbook (http://www.bls.gov/OCO/) leads to engineers and engineering technicians; for each of these general categories, there are estimates of workforce needs, as well as discussions about a variety of sub-areas of engineering. It is easy to imagine a new industry emerging to make wind turbines and the jobs that industry would employ. A search of the DOL Occupational Handbook on energy efficiency is not similarly informative. It is less obvious that there are new jobs associated with manufacturers seeking consultants to help them use less energy, or the owners of buildings hiring contractors to optimize the performance of their heating and cooling systems. ${ }^{8}$

\footnotetext{
${ }^{8}$ The Occupational Information Network (O*Net) Resource Center, (http://www.onetcenter.org/) is being developed to replace the Dictionary of Occupational Titles (DOT), under sponsorship of US Department of Labor Employment and Training Administration. O*Net online (http://online.onetcenter.org/) is a fully operational database which provides easily searchable access to information about energy efficiency-related occupations.
} 


\subsection{Report Structure}

The next chapter describes our approach used to characterize the structure and size of the EESS, with additional information on methods found in technical appendices. ${ }^{9}$ Chapter 3 characterizes the structure and job categories found in the energy efficiency services sector. Chapter 4 presents estimates of the size of the EESS workforce currently (2008), near term (2010), and in the future (2015 and 2020). Chapter 5 provides a snapshot of regional EESS markets by presenting a comparative review and analysis of four recent studies that surveyed employers offering various types of energy efficiency services in Northern California, Connecticut, Massachusetts, and the Pacific Northwest. Chapter 6 discusses the experience of the EESS workforce managers as they seek to grow their staff skills and capabilities and hire new workers. Chapter 7 concludes with implications of this analysis for EESS workforce requirements in light of anticipated increased demand for energy efficiency. In a companion study (Goldman et al. 2010), our research team provides a baseline assessment of the current state of energy efficiency-related education and training programs and analyzes training and education needs to support expected growth in the energy efficiency services workforce.

\footnotetext{
${ }^{9}$ Appendix A includes interview protocols for various sub-sectors of the EESS. Appendix C includes a detailed summary of our approach to estimating energy efficiency spending and employment.
} 


\section{Methodology}

In this chapter, we summarize our methodological approach used to estimate the current and projected size of the EESS workforce, including data and information sources. Characterizing and defining the energy efficiency services sector is a critical initial step in this process. For most sectors, one can use government occupational handbooks and statistics to identify the types and number of jobs associated with that industry. However, for the energy efficiency services sector, we are just beginning to characterize and report occupational categories in government statistics.

\subsection{Literature Review: Other Workforce Studies Compared to Our Approach}

We found several recent studies that develop estimates of energy efficiency-related jobs and/or employment. However, most of these studies have different objectives and scope of industry/economic activity (e.g., "green jobs" or include renewable energy markets) or use different methods (see Table 1). Several studies estimate the potential employment impacts of proposed government programs (Pollin et al. 2008; Apollo Alliance 2004). For example, Pollin et al. (2008) forecast the employment outcomes from a proposal to invest $\$ 100$ billion on "green recovery" programs. Due to the lack of government data on energy efficiency occupations, they created a "synthetic" building retrofit industry input-output model and estimated employment per dollar of spending for that industry. The scope of Bezdek (2007) is quite broad (the "green jobs" market) and includes jobs in the energy efficiency services and renewable energy sector.

In contrast, Apollo Alliance (2004) and U.S. Conference of Mayors (2008) defined a much narrower scope of economic activity and estimated energy efficiency-related jobs limited to the building retrofit market. Ehrhardt-Martinez and Laitner (2008) sum all efficiency-related spending (including transportation) and use an input-output model to generate employment estimates by sector. In a study directed by the Connecticut Clean Energy Fund (CCEF 2009), Navigant Consulting used a bottom-up approach, estimating the size of the energy efficiency workforce in Connecticut by identifying 97 key energy efficiency companies and conducting interviews with contacts at 37 of these companies and extensive secondary research on the remaining firms. Among recent workforce studies, our approach is most similar to the CCEF (2009) study (e.g., an interview-based, bottom-up approach), although we do not account for jobs from firms that manufacture or distribute energy-efficient equipment. ${ }^{10}$

The methods employed also vary significantly between studies. Economists often describe the employment impacts of proposed economic activity by identifying direct, indirect, and induced effects (see Appendix B for more detailed discussion). Direct effects are employment impacts that will occur in meeting the demand for a product or service (e.g., jobs created at an ESCO that develops energy efficiency projects). Indirect effects describe employment that will occur through the "ripple effects" of that activity on the larger economy. Induced effects are those created when employees or firms go out and spend their increased incomes (due to their additional employment/profit or due to energy savings) on consumer goods and services. It is also important to account for substitution effects in estimating net employment impacts (e.g., the

\footnotetext{
${ }^{10}$ See Section 3.1 for a more in-depth discussion of the energy efficiency market supply chain and sub-sectors that are included within our study scope (see Figure 4).
} 
employee hired to sell hammers at a big-box store substitutes for the employee who lost a job at a local hardware store).

Our study only estimates the direct employment effects of energy efficiency investments. We do not attempt to capture indirect or induced effects, in part because a key objective of our study is to assess workforce needs and training that are specific to the EESS. We also decided not to estimate jobs directly involved in the manufacture and distribution (including retail sales) of energy efficiency products and equipment. We took this approach in part because we believe that most of the positive direct employment effects for firms that manufacture or distribute energyefficient equipment due to increased spending on high-efficiency equipment would likely be offset by negative substitution effects (e.g., loss of manufacturing jobs for less efficient products).

Table 1: Other Studies of U.S. Green Jobs Workforce

\begin{tabular}{|c|c|c|}
\hline Source & $\begin{array}{c}\text { Scope and approach used to } \\
\text { estimate energy efficiency-related jobs }\end{array}$ & Job Estimates \\
\hline $\begin{array}{l}\text { The Size of the U.S. } \\
\text { Energy Efficiency } \\
\text { Market } \\
\text { American Council for an } \\
\text { Energy Efficient } \\
\text { Economy (ACEEE) } \\
\text { (Ehrhardt-Martinez and } \\
\text { Laitner 2008) }\end{array}$ & $\begin{array}{l}\text { Scope: Direct and indirect jobs from all EE-related } \\
\text { spending in the residential, commercial, appliances and } \\
\text { electronics, industrial, transportation, and utilities sectors. } \\
\text { Approach: Identifies energy efficiency investments } \\
\text { across multiple sectors, using the ENERGY STAR } \\
\text { standard where possible. Identifies the incremental cost or } \\
\text { "premium" associated with more efficient vs. standard } \\
\text { product. Uses these investment estimates to get job and } \\
\text { industrial output numbers from the IMPLAN database. }\end{array}$ & $\begin{array}{l}\text { - } \mathbf{1 . 6} \text { million current jobs } \\
\text { supported by the EE } \\
\text { sector with } \mathbf{1} \text { million in } \\
\text { buildings } \\
\text { - } \mathbf{2 3 4 , 0 0 0} \text { jobs directly } \\
\text { associated with } \\
\text { "premium” energy } \\
\text { efficiency investments }\end{array}$ \\
\hline $\begin{array}{l}\text { Current and Potential } \\
\text { Green Jobs in the U.S. } \\
\text { Economy } \\
\text { U.S. Conference of } \\
\text { Mayors } \\
\text { (2008) }\end{array}$ & $\begin{array}{l}\text { Scope: Direct EE jobs from retrofitting commercial and } \\
\text { residential buildings. } \\
\text { Approach: Assumes a fixed number of jobs per unit of } \\
\text { energy saved, and assumes an average savings of } 35 \% \text { of } \\
\text { building energy by } 2038 \text { ( } 1.2 \% \text { savings per year). Given } \\
\text { this savings level and using their jobs per unit energy } \\
\text { saved, they forecast annual employment. }\end{array}$ & $\begin{array}{l}\mathbf{7 5 0 , 0 0 0} \text { “green jobs” in } \\
\text { 2006, with } \mathbf{4 . 2} \text { million } \\
\text { jobs forecasted for } 2038 \\
\text { - } \mathbf{8 1 , 0 0 0} \text { jobs in building } \\
\text { retrofit work forecasted } \\
\text { for } 2038 \text {, starting by } \\
2018 .\end{array}$ \\
\hline $\begin{array}{l}\text { Green Recovery: A } \\
\text { Program to Create Good } \\
\text { Jobs and Start Building } \\
\text { a Low-Carbon Economy } \\
\text { University of Mass and } \\
\text { the Center for American } \\
\text { Progress } \\
\text { (Pollin et al. 2008) }\end{array}$ & $\begin{array}{l}\text { Scope: Forecasts direct, indirect, and induced } \\
\text { employment impacts from a proposed } \$ 100 \text { billion "green } \\
\text { recovery" program, part of which focuses on the building } \\
\text { retrofit industry } \\
\text { Approach: Due to lack of government data on EE } \\
\text { occupations, authors create a "synthetic" building retrofit } \\
\text { industry input-output model to find employment per } \\
\text { dollar of spending. Based on assumptions about new } \\
\text { spending through a green recovery program, they } \\
\text { calculate expected employment impacts. }\end{array}$ & $\begin{array}{l}\text { Potential to create } 2 \\
\text { million additional } \\
\text { "green jobs" (direct, } \\
\text { indirect, and induced) } \\
\text { across several sectors in } \\
\text { two years; of which } \\
\mathbf{8 0 0 , 0 0 0 ~ j o b s ~ c o u l d ~ p u t ~} \\
\text { construction workers } \\
\text { back to work. }\end{array}$ \\
\hline $\begin{array}{l}\text { Renewable Energy and } \\
\text { Energy Efficiency: } \\
\text { Economic Drivers for } \\
\text { the } 20^{\text {th }} \text { Century } \\
\text { American Solar Energy } \\
\text { Society } \\
\text { (Bedzek 2007) }\end{array}$ & $\begin{array}{l}\text { Scope: Direct and indirect jobs across multiple sectors } \\
\text { including insulation, ESCO activity, all ENERGY STAR } \\
\text { appliances and equipment, ratepayer spending, vehicles } \\
\text { that get } 10 \% \text { better mileage than the CAFE standards, and } \\
\text { the U.S. recycling and reuse industries. } \\
\text { Approach: Estimates the spending in each sector and } \\
\text { uses an input-output model to estimate employment }\end{array}$ & $\begin{array}{l}\text { - } 3.5 \text { million direct energy } \\
\text { efficiency jobs and } \mathbf{8} \\
\text { million direct and } \\
\text { indirect energy } \\
\text { efficiency jobs in } 2006 \text {. }\end{array}$ \\
\hline
\end{tabular}




\begin{tabular}{|c|c|c|}
\hline & impacts. & \\
\hline $\begin{array}{l}\text { New Energy for New } \\
\text { America } \\
\text { Apollo Alliance } \\
\text { (2004) }\end{array}$ & $\begin{array}{l}\text { Scope: Direct and indirect jobs created as a result of } \\
\text { significant public investment, including EE financing, an } \\
\text { income tax credit for retrofits, programs to support high } \\
\text { performance buildings, and buildings R\&D } \\
\text { Approach: Economic modeling by Perryman Group to } \\
\text { translate public investments to employment impacts }\end{array}$ & $\begin{array}{l}\text { - Potential to create } \\
\mathbf{8 2 7 , 0 0 0} \text { jobs over } 10 \\
\text { years to make new and } \\
\text { existing buildings } \\
\text { energy-efficient, } \\
\text { assuming a significant } \\
\text { public investment. }\end{array}$ \\
\hline $\begin{array}{l}\text { CT Renewable Energy/ } \\
\text { Energy Efficiency } \\
\text { Economy Baseline Study } \\
\text { Navigant Consulting for } \\
\text { the Connecticut Clean } \\
\text { Energy Fund (CCEF) and } \\
\text { the Connecticut Energy } \\
\text { Efficiency Fund } \\
\text { (Navigant and CCEF } \\
\text { 2009) }\end{array}$ & $\begin{array}{l}\text { Scope: Direct, indirect, and induced jobs from EE-related } \\
\text { products and services in Connecticut. } \\
\text { Approach: Identifies } 97 \text { key energy efficiency } \\
\text { companies in Connecticut; conducted interviews with } 37 \\
\text { of these companies and conducted secondary research on } \\
\text { the remaining } 60 \text {. Direct jobs are those reported by these } \\
\text { companies. Indirect and induced jobs are estimated } \\
\text { assuming a multiplier of } 1.6 \text { times direct jobs, based on } \\
\text { the REMI model }\end{array}$ & $\begin{array}{l}\text { - Currently 2,675 direct } \\
\text { jobs and 4,280 indirect } \\
\text { or induced jobs in } \\
\text { Connecticut. }\end{array}$ \\
\hline
\end{tabular}

\subsection{Our Approach and Scope}

Our study draws upon approximately 300 interviews with program administrators, education and training providers and a variety of EESS employers and trade associations; communications with over 50 sector experts; as well as an extensive review of the literature and publicly available data. The interviews sought to establish the baseline workforce environment for each target group, assess current issues with hiring, and identify training and education needs. We also asked interviewees for their expectations regarding hiring and workforce expansion in the near term (see Appendix A for interview guides). We combine findings from these interviews with data on current funding for energy efficiency and our projections of energy efficiency program spending and market activity through 2020 to estimate the size of the current and future EESS workforce, and also to provide qualitative insights into the workforce challenges for this sector.

As others have noted, separating out "efficiency jobs” from the many existing products and services that involve energy efficiency in some way is extremely challenging (see EhrhardtMartinez and Laitner 2008). Energy efficiency may be a primary motive that drives investment in new equipment by a building owner. Conversely, new products or equipment may become more efficient over time (because of technological progress or standards), but energy efficiency may have little or no explicit role in the decision-making criteria used by consumers in their appliance or equipment purchase decisions.

We limit our scope primarily to estimating workforce size and needs of that portion of the EESS market supply chain that focuses on deployment and installation of energy efficiency products and services (see Figure 4). Our bottom-up approach focuses on those energy efficiency programs and market-driven activities in which market actors and end users regard the energy and dollar savings derived from energy efficiency investments as an important, significant driver of consumer demand. We make this distinction both because the jobs that require the most 
energy efficiency-specific training fall into this scope, and also because data are more readily available for this portion of the energy efficiency services sector.

To develop estimates of current and projected employment in the EESS, we characterized and analyzed existing energy efficiency program and market activity for the following sub-sectors: ${ }^{11}$

- Ratepayer-funded energy efficiency activity, including:

o Program administrator workforce

o Program implementation contractor workforce

o Program support contractor workforce

o Building and construction trades workforce that implements projects as part of ratepayer-funded activity

- Low-income weatherization workforce, including:

o Program administrator workforce

o Contractor workforce that implements weatherization projects

- Energy Service Company (ESCO) workforce, including:

o ESCOs that develop, construct and maintain energy efficiency projects

o Building and construction trades workforce that are involved in installation of ESCO projects, acting as subcontractors (e.g., lighting, HVAC contractors)

- Insulation workforce, including:

o Envelope insulation

o Mechanical insulation

- Federal and state energy efficiency programs, including the state energy office workforce

We believe that these sub-sectors capture the bulk of the policy-driven and market activity in the EESS for which it is relatively easy to characterize energy efficiency investment and spending (and derive employment estimates). However, we acknowledge that our approach is not comprehensive and does not fully account for energy efficiency-related market activity and investment in a number of areas, including:

\section{High-efficiency appliances, electronics and office equipment -}

Our approach captures energy efficiency spending (and the EESS workforce) involved in the high-efficiency appliance, electronics and office equipment market that participate directly in ratepayer-funded energy efficiency programs. The size of the market for high-efficiency appliances and electronics depends on the definition of "high-efficiency." For example, ErhardtMartinez and Laitner (2008) use ENERGY STAR designations for approximately 40 products in their study to estimate the size of the high-efficiency appliance, electronics and office equipment market. They estimate the efficiency premium investment at about \$10B in 2004 and note that ENERGY STAR products have varying market saturation across products: ENERGY STAR

\footnotetext{
${ }^{11}$ See Chapter 3 for a more detailed description these sub-sectors.
} 
market share ranges from 75-99\% in office equipment, $50-80 \%$ in home electronics, and from $27-78 \%$ for various residential appliances. ${ }^{12}$ Clearly, ratepayer-funded programs are using more stringent definitions of "high-efficiency" in their programs and typically do not provide incentives for all ENERGY STAR products designated by EPA and DOE. Many ratepayerfunded energy efficiency programs exclude those ENERGY STAR products that have very high market shares or which do not pass cost-effectiveness screening guidelines for ratepayer-funded energy efficiency programs.

\section{High-efficiency windows -}

Our approach is limited and captures only energy efficiency spending (and EESS workforce) for high-efficiency windows that are installed through either ratepayer-funded, state energy, or lowincome weatherization programs. Again, the size of the market for high-efficiency windows depends on the definition of "high-efficiency." Most windows currently sold have the ENERGY STAR label. We believe that the majority of window sales to the existing buildings are necessitated by end-of-life replacement or are bought based on aesthetic considerations occasioned by remodeling. Windows with significantly higher efficiency values than the highest efficiency ENERGY STAR-labeled windows are currently available, although their market share is very low. In estimating the size of the high-efficiency window market, a key issue is whether to use the ENERGY STAR label as the defining feature. Because of the high market penetration of ENERGY STAR windows that have become standard practice, the very low market penetration of super-efficient windows, and the fact that energy efficiency is not a primary driver of window purchases, we chose not to develop a window industry-specific spending and employment estimate for this EESS sub-sector.

\section{Industrial Energy Efficiency -}

Our approach is limited to the energy efficiency spending (and EESS workforce) for industrial customers that participate in ratepayer-funded energy efficiency programs. ${ }^{13}$ The landscape of industrial energy efficiency is on the cusp of great change based on our discussions with energy efficiency experts active in this sector. Previous ISO standards (9001 and 14001) have been adopted rapidly by industry. ISO 50001 is an energy management system standard that will establish a comprehensive framework for industrial plants, facilities and organizations to manage energy. ${ }^{14}$ The draft ISO5001 standard was issued in April 2010 and the final standard is expected to be adopted in 2011. The U.S. DOE is also developing and pilot testing the Superior Energy Performance program that will conform to ISO50001 and requires validation of energy

\footnotetext{
12 Erhardt-Martinez and Laitner define the premium efficiency investment as the difference in cost between the efficient and non-efficient product.

${ }^{13}$ Ehrhardt-Martinez and Laitner claim that domestic and international competitiveness is a huge driver of efficiency in the industrial sector and spending by industry on energy efficiency was roughly $\$ 75$ billion in 2004, using their definition of efficiency.

14 The ISO50001 standard is being developed by a Project Committee (\#242) that includes 42 countries. The effort is led by the U.S. and Brazil. The Energy Management System model is based on the Plan-Do- Check-Act. An industrial facility/company would adopt the following elements to comply with the standard: (1) Official energy policy statement from organization top management, (2) Cross-divisional management team that oversees energy management, (3) Energy planning process, (4) Baseline of the organization's energy use, (5) Identification of energy performance indicators, (6) Energy objectives and targets for energy performance improvement at relevant functions and processes, (7) Action plan to meet targets, (8) Operating controls and procedures that address energy purchase, use and disposal, (9) Measurement, management and documentation, and (10) Periodic reporting of progress.
} 
performance improvement (McKane et al. 2009) ${ }^{15}$ These efforts are expected to lead to significant increases in energy efficiency investment by industry. Thus, our approach in this study only partially captures expected energy efficiency market activity among industrial customers in the future. Further study is required to assess the employment and spending impacts of ISO 50001 and Superior Energy Performance and the workforce needs to support these new initiatives.

\subsubsection{Case Study Approach}

In order to implement our "bottom-up" approach, we focused on a subset of states currently active in energy efficiency in order to develop data on spending and employment information for some sub-sectors (e.g., ratepayer-funded programs and ESCO market activity) and as the sampling frame for our interviews with program administrators, program implementation contractors, and building professional and trade associations. We used three criteria to select the states on which to focus data collection:

1. Spending levels for ratepayer-funded energy efficiency programs, based on analysis of 2007 energy efficiency program expenditures (CEE 2007a);

2. The activity of ESCOs, selected as a proxy for market spending on retrofit energy efficiency activity in the commercial/institutional market (Hopper and Goldman 2007); and

3. Geographic balance to ensure that each region of the country was represented.

We selected 11 states (see Figure 2): California, Connecticut, Illinois, Iowa, Maryland, Massachusetts, New Jersey, New York, Texas, Washington, and Wisconsin. These 11 states represent: roughly $75 \%$ of all 2008 ratepayer-funded energy efficiency (CEE 2008), about 45\% of the ESCO-reported activity (Goldman 2009), and $40 \%$ of the U.S. population (U.S. Census Bureau 2009).

\footnotetext{
15 The design of the Superior Energy Performance program allows industrial facilities/plants to qualify under one of three tiers (Partner, Registered Partner, Certified Partner) at various performance levels (Silver, Gold and Platinum) that involve energy intensity improvements and rating on "best practices" scorecard.
} 


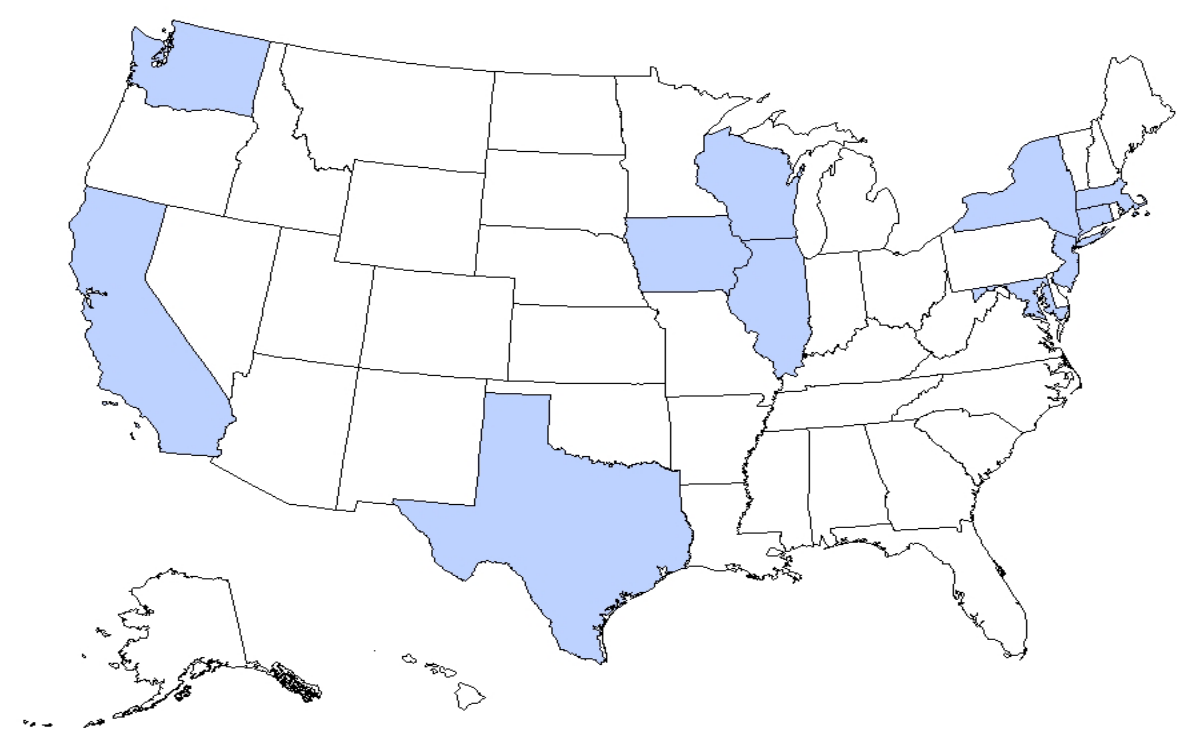

Figure 2: Case Study States

\subsection{Methods for Estimating Current and Future Employment}

In estimating employment in the EESS, we focused on estimating person years of employment (PYE). PYE is defined as one person working full time in the EESS for one year. This is different from total number of employees, which can include people who work part time or work part time on EESS-specific activities. For example, two half-time employees working on EESSspecific activities equal one PYE. ${ }^{16}$ We count only the fraction of that person-year that is spent on installing high-efficiency products in our estimates of EESS workforce size.

Figure 3 provides a graphical representation of steps we used to estimate spending and current and future employment for each of the targeted sub-sectors within the EESS. In Step 1, we estimate current energy efficiency spending and PYE for the 11 case study states, drawing from interview results with program administrators and program implementation contractors who provided information on program spending and number of employees. In Step 2, we calculate the PYE per million dollars (PYE/\$1M) of spending for that sub-sector. In Step 3, we estimate the total spending for energy efficiency within the sub-sector (e.g., ratepayer-funded energy efficiency) and use the PYE $/ \$ 1 M$ spending ratio from the 11-state sample to extrapolate to the remaining states, in order to estimate current U.S. employment in that sub-sector (Step 4). In Step 5, we develop two scenarios of future energy efficiency spending in 2010, 2015, and 2020 and in Step 6 we use the PYE per million dollars spending ratio to estimate future employment in those years.

We also estimate the total number of employees in the energy efficiency services sector, based on our judgment of the proportions of jobs that are full- and part-time and the estimated time

\footnotetext{
${ }^{16}$ Full-time equivalent (FTE) may be a more familiar acronym used to describe workforce staffing levels. FTE does not explicitly include duration; for our purpose, FTE should be understood as referring to full-time employment over one year's duration given one year's funding.
} 
spent providing energy efficiency services for various job positions (e.g., contractors, consultants) in each sub-sector of the EESS.

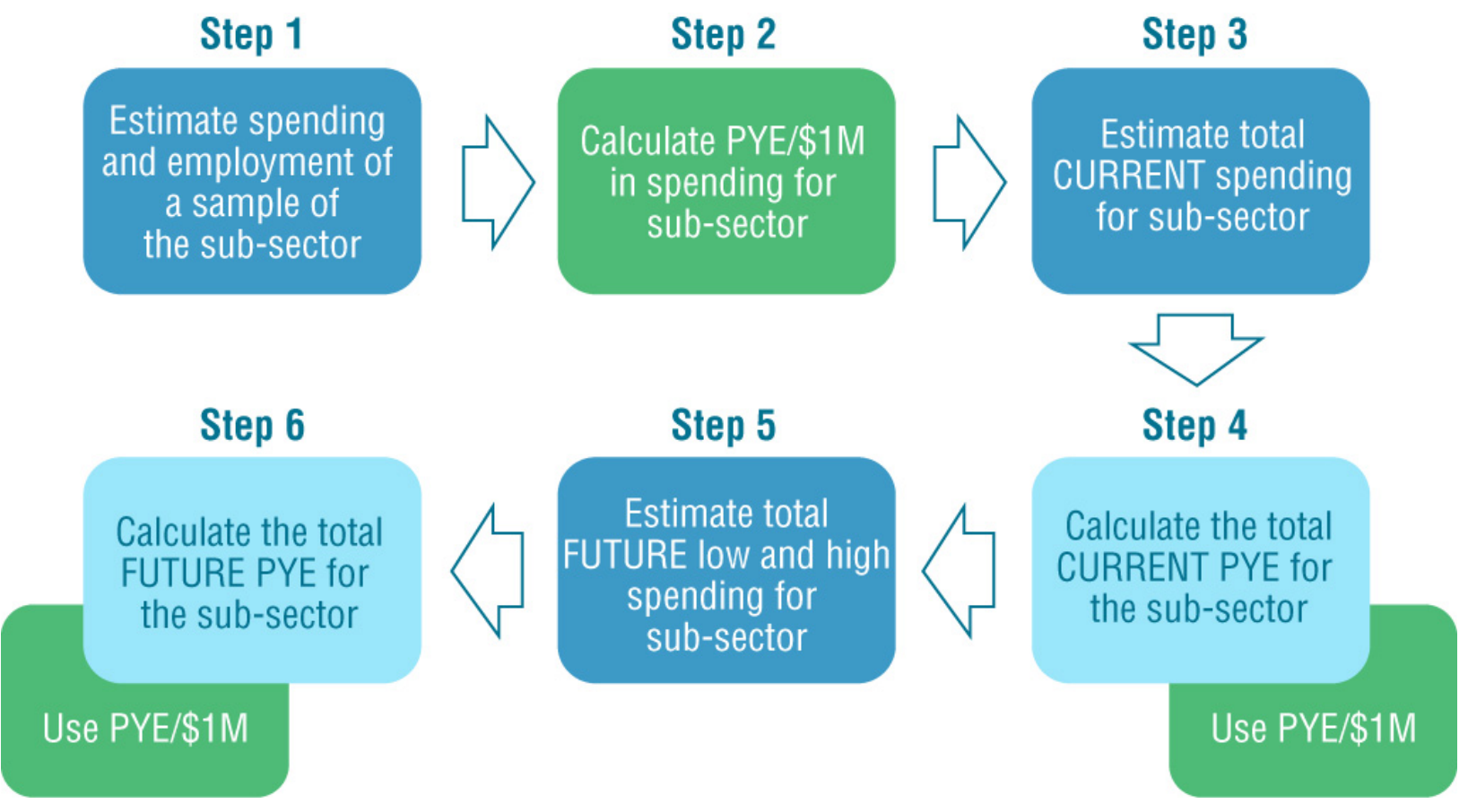

Figure 3: Method for Estimating Current and Future Person-Years of Employment

\subsubsection{Current Employment}

Our estimates of current size of the EESS workforce are based on:

- Self-reported workforce data from managers of organizations implementing energy efficiency (e.g., program administrators, program implementation contractors, ESCOs);

- Interviews with representatives of trade and professional organizations and associations whose members design, install, operate and maintain energy-efficient solutions;

- Interviews with knowledgeable industry informants; and

- Data obtained from public sources (e.g., state regulators, EIA, CEE, and prior LBNL research).

Table 2 summarizes our specific data sources for each sub-sector of the EESS.

Table 2: Sources of Data for Estimating Current Workforce Size

\begin{tabular}{||l|l|l||}
\hline \hline Sub-sector of the EESS & \multicolumn{1}{|c|}{ Current Spending Estimates } & \multicolumn{1}{c|}{$\begin{array}{c}\text { Person-Years of Employment } \\
\text { per \$1M spending }\end{array}$} \\
\hline $\begin{array}{l}\text { Ratepayer-funded } \\
\text { efficiency activity }\end{array}$ & $\begin{array}{l}\text { Program Administrators } \\
\text { 17 - Obtained } \\
\text { 2007 budget data from interviews with }\end{array}$ & $\begin{array}{l}\text { Program Administrators - Workforce data for } \\
\text { 2007/2008 provided by interviewed program }\end{array}$ \\
\hline
\end{tabular}

\footnotetext{
${ }^{17}$ For definitions of Program Administrators, Program Implementation Contractors, and Program Support Contractors see Chapter 3.
} 


\begin{tabular}{|c|c|c|}
\hline & $\begin{array}{l}38 \text { Program Administrators (PA). } \\
\text { Aggregated administrator data by state } \\
\text { for } 11 \text { states. Budgets for non- } \\
\text { respondents in the } 11 \text { states estimated } \\
\text { as difference between surveyed } \\
\text { responses for a state and CEE } 2007 \\
\text { state totals. Obtained budgets for } \\
\text { remaining } 39 \text { states from CEE (2007). } \\
\text { Program Implementation } \\
\text { Contractors (PIC) - Used PA budgets } \\
\text { as described above. } \\
\text { Program Support Contractors (PSC) } \\
\text { - Used PA respondents' estimates of } \\
\text { incentive budgets. Calculated average } \\
\text { of proportion of budget going to } \\
\text { incentives and all other costs. } \\
\text { Building and Construction Trades } \\
\text { conducting ratepayer-funded activity } \\
\text { - Used PA total and incentive budgets } \\
\text { reported by PA respondents. } \\
\text { Interviewed key informants on average } \\
\text { proportion of incentive cost to total EE } \\
\text { project cost. Estimated ratio to convert } \\
\text { from incentives to total project costs. } \\
\text { Used Connecticut data (Navigant 2009) } \\
\text { and key informants for allocating } \\
\text { project costs into labor and equipment } \\
\text { components. Estimated labor’s share of } \\
\text { total project cost. }\end{array}$ & $\begin{array}{l}\text { administrators. Conducted regression analysis of } \\
\text { workforce on budget. Used regression to estimate } \\
\text { workforce of non-respondents. For } 39 \text { non-surveyed } \\
\text { states, assumed FTE in relation to budget is low; we } \\
\text { imputed results from the surveyed states with the } \\
\text { lowest FTE to budget ratio. } \\
\text { Program Implementation Contractors - Workforce } \\
\text { data for } 2008 \text { provided by } 23 \text { interviewed program } \\
\text { implementation contractors and } 11 \text { efficiency program } \\
\text { planning and evaluation consultants. Used respondents' } \\
\text { estimates of percent of work done in each of } 11 \text { states } \\
\text { to allocate staff by state. } \\
\text { Program Support Contractors - Workforce estimates } \\
\text { for CA, IA, NY, and WA based on prior program } \\
\text { evaluations conducted by Research Into Action. } \\
\text { Estimated for remaining states as equal to one-half } \\
\text { program implementation contractor workforce. } \\
\text { Corroborated validity of assumptions by estimating } \\
\text { total PA budget needed to cover PA, PIC, and PSC and } \\
\text { verified outcome was consistent with survey data on } \\
\text { proportion of budget not allocated to incentives. } \\
\text { Building and Construction Trades conducting } \\
\text { ratepayer-funded activity - Used Connecticut data } \\
\text { (Navigant 2009) and BLS Occupational Code } 472130 \\
\text { (insulation) data on average organization revenues per } \\
\text { FTE. Re-analyzed Navigant data, corroborated with } \\
\text { BLS data, and estimated average revenues per FTE. } \\
\text { Estimated person-years of building and construction } \\
\text { trades employment associated with labor's share of } \\
\text { total project cost, as driven by PA budgets. }\end{array}$ \\
\hline $\begin{array}{l}\text { Low-income } \\
\text { weatherization }\end{array}$ & $\begin{array}{l}\text { Obtained } 2007 \text { budget data (NASCSP } \\
\text { 2007) for } 11 \text { states and national for } \\
\text { DOE, LIHEAP, and “other.” Removed } \\
\text { estimates of the low-income program } \\
\text { administrator budgets from the "other" } \\
\text { category (CEE 2007). }\end{array}$ & $\begin{array}{l}\text { Developed an estimate of PYE/\$1M in spending from } \\
\text { an analysis of detailed survey data collected on } \\
\text { Massachusetts low-income weatherization activity } \\
\text { (New England Clean Energy Council 2009). }\end{array}$ \\
\hline ESCOs & $\begin{array}{l}\text { Used Goldman and Hopper (2007) } \\
\text { estimates of } 2006 \text { ESCO EE revenue } \\
\text { and ESCO respondents' forecast of } \\
\text { growth in revenues to estimate } 2008 \\
\text { revenues. }\end{array}$ & $\begin{array}{l}\text { Workforce data for } 2008 \text { provided by } 9 \text { interviewed } \\
\text { ESCOs (over 50\% of market as defined by } 2006 \\
\text { revenues). Used interview data to re-analyze Goldman } \\
\text { and Hopper (2007) data to estimate } 2008 \text { workforce for } \\
\text { entire ESCO market, including contractors to ESCOs. }\end{array}$ \\
\hline Insulation & $\begin{array}{l}\text { Applied to the workforce estimate (see } \\
\text { next column) the average revenue per } \\
\text { insulation worker as reported by the } \\
2002 \text { Economic Census (US Census } \\
\text { Bureau) escalated for inflation. }\end{array}$ & $\begin{array}{l}\text { Used Bureau of Labor Statistics data on number of } \\
\text { workers in occupational codes } 472131 \text { (insulation } \\
\text { workers: floor, ceiling, and wall) and } 472132 \\
\text { (insulation workers: mechanical) working in five } \\
\text { industry codes (2361-Residential Building } \\
\text { Construction; 2362-Nonresidential Building } \\
\text { Construction; 2382-Building Equipment Contractors; } \\
\text { 2383-Building Finishing Contractors; 2389-Other } \\
\text { Specialty Trade Contractors). Added to insulation } \\
\text { workers estimated overhead workers of administrative } \\
\text { support occupations (Occ. Code 43-0000) and } \\
\text { management, business, and financial occupations (Occ. } \\
\text { Code 11-1300). }\end{array}$ \\
\hline Federal and state & Obtained 2008 budget data from EERE & Used FY 2010 Federal Budget for DOE-EERE actual \\
\hline
\end{tabular}




\begin{tabular}{|l|l|l|}
\hline $\begin{array}{l}\text { government EERE } \\
\text { offices }\end{array}$ & $\begin{array}{l}\text { website, selecting EE program } \\
\text { components and excluding low-income } \\
\text { weatherization }\end{array}$ & $\begin{array}{l}\text { FTE and applied percent of programs that were EE to } \\
\text { total FTE. Obtained 2008 efficiency workforce data for } \\
\text { state energy offices from a 2009 NASEO study. }\end{array}$ \\
\hline
\end{tabular}

Table 3 summarizes our estimates of 2008 spending in each sub-sector of the EESS as well as values that we use for PYE/\$1M of spending. Employment-to-spending ratios vary across energy efficiency services markets from a high of 8.9 PYE for weatherization programs to a low of 2.5 PYE for ESCO projects per \$1M of spending.

Table 3: PYE and Spending for Each Sub-Sector

\begin{tabular}{||l|c|c|}
\hline \multicolumn{1}{|c|}{ Activity } & $\begin{array}{c}\text { Estimated 2008 } \\
\text { Spending } \\
\text { (in \$B) }\end{array}$ & $\begin{array}{c}\text { Person-Years of } \\
\text { Employment } \\
\text { per \$1M }\end{array}$ \\
\hline Ratepayer-funded efficiency activity & $\$ 5.2$ & 6.2 \\
\hline Low-income weatherization & $\$ 0.53$ & 8.9 \\
\hline ESCOs & $\$ 4.9$ & 2.5 \\
\hline Insulation & $\$ 7.1$ & 8.9 \\
\hline Federal and state govt EERE offices & $\$ 0.24$ & 6.5 \\
\hline
\end{tabular}

\subsubsection{Future Employment}

Our estimates of the future size of the EESS assume that similar types of trades and occupations will be active in the future providing energy efficiency services in similar types of organizations that currently pursue energy efficiency (see Figure 5, Figure 6 and Figure 7). To estimate the future size of the EESS workforce, we project future spending on energy efficiency and then apply the ratio of PYE/\$1M of spending for each sub-sector of the EESS to estimate PYE in future years. We develop a low and high scenario of energy efficiency spending over several time periods: near-term (2010), intermediate-term (2015), and long-term (2020); see Table 4 and Appendices $\mathrm{C}$ and D for further details behind these projections.

\section{Table 4: Sources of Data for Estimating Projections of Future Spending}

\begin{tabular}{|l|l||}
\hline Sub-sector of the EESS & \multicolumn{1}{c|}{ Basis for Future Spending Projections } \\
\hline $\begin{array}{l}\text { Ratepayer-funded } \\
\text { efficiency activity }\end{array}$ & $\begin{array}{l}\text { Recent study by Barbose et al. 2009 which provides low and high } \\
\text { estimates (see Appendix D) }\end{array}$ \\
\hline $\begin{array}{l}\text { Low-income } \\
\text { weatherization }\end{array}$ & $\begin{array}{l}\text { Created scenarios for high and low projections: } \\
\text { Low - Spending decreases after ARRA funds run out, then only } \\
\text { modest increase in spending through 2020 } \\
\text { High - Ongoing aggressive spending after ARRA funds run out; } \\
\text { increasing through 2020 }\end{array}$ \\
\hline ESCOs & $\begin{array}{l}\text { Estimates of future ESCO spending developed from several sources: } \\
\text { 1) results of the 2006 ESCO survey (Hopper and Goldman 2007) } \\
\text { that provided ESCO projections for the near term, 2) interviews with } \\
\text { representatives from nine ESCOs, and 3) a Delphi process that } \\
\text { involved discussions with several experts who consult to the ESCO } \\
\text { industry. We developed two scenarios to project future ESCO } \\
\text { revenues: }\end{array}$ \\
\hline
\end{tabular}




\begin{tabular}{|l|l||}
\hline & $\begin{array}{l}\text { Low - A “business-as-usual” scenario with spending on ESCO } \\
\text { activity increasing by 8\% per year to 2020 } \\
\text { High - A “high growth" scenario with spending on ESCO activity } \\
\text { increasing by 12\% per year to 2020 }\end{array}$ \\
\hline Insulation & $\begin{array}{l}\text { We used two sources for high and low projections: } \\
\text { Low - Growth forecast published by the Bureau of Labor Statistics } \\
\text { High - Used the same rate of growth (12\% per year) as the high } \\
\text { scenario for ratepayer-funded programs }\end{array}$ \\
\hline $\begin{array}{l}\text { For 2010: Assumed additional budget over 2008 by summing the } \\
\text { DOE EERE non-weatherization ARRA-funded programs, plus the } \\
\text { ARRA funds for DOD, GSA, and VA programs, and dividing by 3 } \\
\text { years to derive estimated spending for 2010 } \\
\text { For 2015 and 2020: } \\
\text { governmen and state } \\
\text { offices }\end{array}$ & $\begin{array}{l}\text { Low - Took proportion of DOE EERE programs that were EE only } \\
\text { in 2008 (excluding weatherization); multiplied by total federal EERE } \\
\text { forecast budget for 2015 } \\
\text { High - Estimated that the 2008 budget devoted to EE (excluding } \\
\text { weatherization) would increase by 5\% per year. }\end{array}$ \\
\hline \hline
\end{tabular}




\section{Characterizing the Energy Efficiency Services Sector}

In this section, we provide an overview of the market supply chain for energy efficiency and describe the types of firms and institutions that provide various types of energy efficiency-related services in the commercial, residential, and industrial markets.. We then describe the structure of several types of organizations in the EESS (e.g., program administrators, program implementation contractors and ESCOs) and how they establish and use various occupational categories to deliver services.

\subsection{Energy Efficiency Market Supply Chain}

The market supply chain for energy efficiency spans product development, manufacturing, wholesale and retail distribution, deployment (e.g., project design, construction, evaluation) and operations/maintenance (see Figure 4) [CCEF 2009]. In this study, we limit our scope primarily to estimating workforce size and needs of that portion of the EESS market supply chain that focuses on deployment and installation of energy efficiency products and measures (e.g., planning and project management, consulting and auditing, construction and installation and evaluation, monitoring and verification). Operations and maintenance of high-efficiency equipment often is provided by in-house employees who work for large end users or is outsourced to a third-party service operations and maintenance (O\&M) provider. ${ }^{18}$

\begin{tabular}{|c|c|c|c|c|c|}
\hline \multirow[b]{2}{*}{$\begin{array}{l}\text { Manufacturing } \\
\& \text { Distribution }\end{array}$} & \multicolumn{4}{|c|}{ Study Scope } & \multirow[b]{2}{*}{$\begin{array}{l}\text { Operations \& } \\
\text { Maintenance }\end{array}$} \\
\hline & $\begin{array}{c}\text { Planning \& } \\
\text { Project } \\
\text { Management }\end{array}$ & $\begin{array}{l}\text { Consulting \& } \\
\text { Auditing }\end{array}$ & $\begin{array}{l}\text { Construction } \\
\& \text { Installation }\end{array}$ & $\begin{array}{l}\text { Evaluation } \\
\text { Monitoring \& } \\
\text { Verification }\end{array}$ & \\
\hline $\begin{array}{l}\text { - Firms designing \& } \\
\text { manufacturing } \mathrm{EE} \\
\text { equipment } \\
\text { - Wholesale } \\
\text { distributors of } \mathrm{EE} \\
\text { equipment } \\
\text { - Retail distributors } \\
\text { of } \mathrm{EE} \text { equipment }\end{array}$ & $\begin{array}{l}\text { - Program } \\
\text { administrators } \\
\text { - Federal and state } \\
\text { EERE offices } \\
\text { - Implementation } \\
\text { contractors } \\
\text { - Technical } \\
\text { support service } \\
\text { providers } \\
\text {-Energy } \\
\text { management } \\
\text { firms }\end{array}$ & $\begin{array}{l}\text { - Design \& } \\
\text { engineering firms } \\
\text { - Implementation } \\
\text { contractors } \\
\text { - Technical } \\
\text { support service } \\
\text { providers } \\
\text { - ESCOs } \\
\text { - Local Wx } \\
\text { agencies } \\
\text { - Energy } \\
\text { management } \\
\text { firms } \\
\text { - Accreditation } \\
\text { consultants }\end{array}$ & $\begin{array}{l}\text { - Design \& } \\
\text { engineering firms } \\
\text { - Building \& } \\
\text { construction } \\
\text { firms } \\
\text { - Insulation firms } \\
\text { - Technical } \\
\text { support service } \\
\text { providers } \\
\text { - ESCOS } \\
\text { - Local Wx } \\
\text { agencies }\end{array}$ & $\begin{array}{l}\text { - Program } \\
\text { administrators } \\
\text { - Federal and state } \\
\text { EERE offices } \\
\text { - Implementation } \\
\text { contractors } \\
\text { - Technical } \\
\text { support service } \\
\text { providers } \\
\text { - ESCOs } \\
\text { - Energy } \\
\text { management } \\
\text { firms } \\
\text { - Evaluation } \\
\text { consultants }\end{array}$ & $\begin{array}{l}\text { - Building owners \& } \\
\text { managers } \\
\text { - Facilities } \\
\text { operators }\end{array}$ \\
\hline
\end{tabular}

Figure 4: Energy Efficiency Market Value Chain

Source: adapted from CCEF, 2009

\footnotetext{
${ }^{18}$ Our workforce size estimates do account for O\&M services provided by ESCOs, but not other types of firms that provide O\&M services related to energy efficient equipment.
} 


\subsection{Structure of Energy Efficiency Services Sector and Types of Energy Efficiency Service Providers}

It is also useful to characterize the types of firms that are involved in providing energy efficiency products and services in key markets: commercial/institutional (Figure 5), residential (Figure 6), and industrial (Figure 7). These market characterization diagrams highlight a number of themes about the structure of the energy efficiency services sector.

- For some companies and organizations, energy efficiency is their primary business or activity (e.g., federal and state energy efficiency administrators, program implementation contractors, some ESCOs).

- For many of the firms involved in the EESS, energy efficiency may not be their core business, but comprises a business line or service offering (e.g., design/engineering firms, equipment providers). Utility program administrators also fall into this latter category as energy efficiency departments typically account for a small portion of utility revenues and employees.

- We use the convention of lighter-colored boxes with dotted outlines for job categories or firm types which involve occupations that have emerged primarily as a result of the development of the EESS, and darker-colored boxes with solid outlines for firms which involve job categories that exist outside of the EESS. In all three figures, the second row of boxes (blue ovals), represent job categories of staff employed by organizations shown in the top row of rectangular boxes (Federal and State EE Administrators, Program Administrators and Program Implementation Contractors). Ovals which appear under the various firm types (e.g., Design and Engineering Firms, Technical Support Services Firms), represent firms which provide specialized services corresponding to the various firm types. Ovals which appear under the rectangular box, "Facility/Building Owner/Manager's Staff,” represent energy efficiency-related job categories at facilities.

- The market characterization diagrams use a somewhat top-down view of the market from a program administrator's perspective. ${ }^{19}$ Program administrators rely heavily on various types of market actors and trade allies to design, deliver, and implement high efficiency products and services to facility and building owners. Thus, the bulk of the employment and jobs created from energy efficiency programs typically occur among these market actors and trade allies.

- In Figure 6, we provide a top-down view of the residential energy efficiency marketplace, including program administrators, key trade allies and service and equipment providers. We explicitly include "local weatherization agencies" to highlight the fact these community-based organizations typically administer and implement low-income and limited-income weatherization programs using Federal Weatherization Assistance

\footnotetext{
${ }^{19}$ We take this approach, in part, because historically, our view is that a significant amount of energy efficiency investments have been driven by various types of public policies (e.g., Federal \& state programs). Federal and state EERE administrators include the staffs of state energy offices. Program administrators oversee ratepayer-funded efficiency programs which can be administered by utilities, state agencies, or third-party firms; hence we use the broader term "program administrator" in lieu of "utility."
} 
Program (WAP), Low-Income Home Energy Assistance Program (LIHEAP), and other funding from states and private sources. ${ }^{20}$

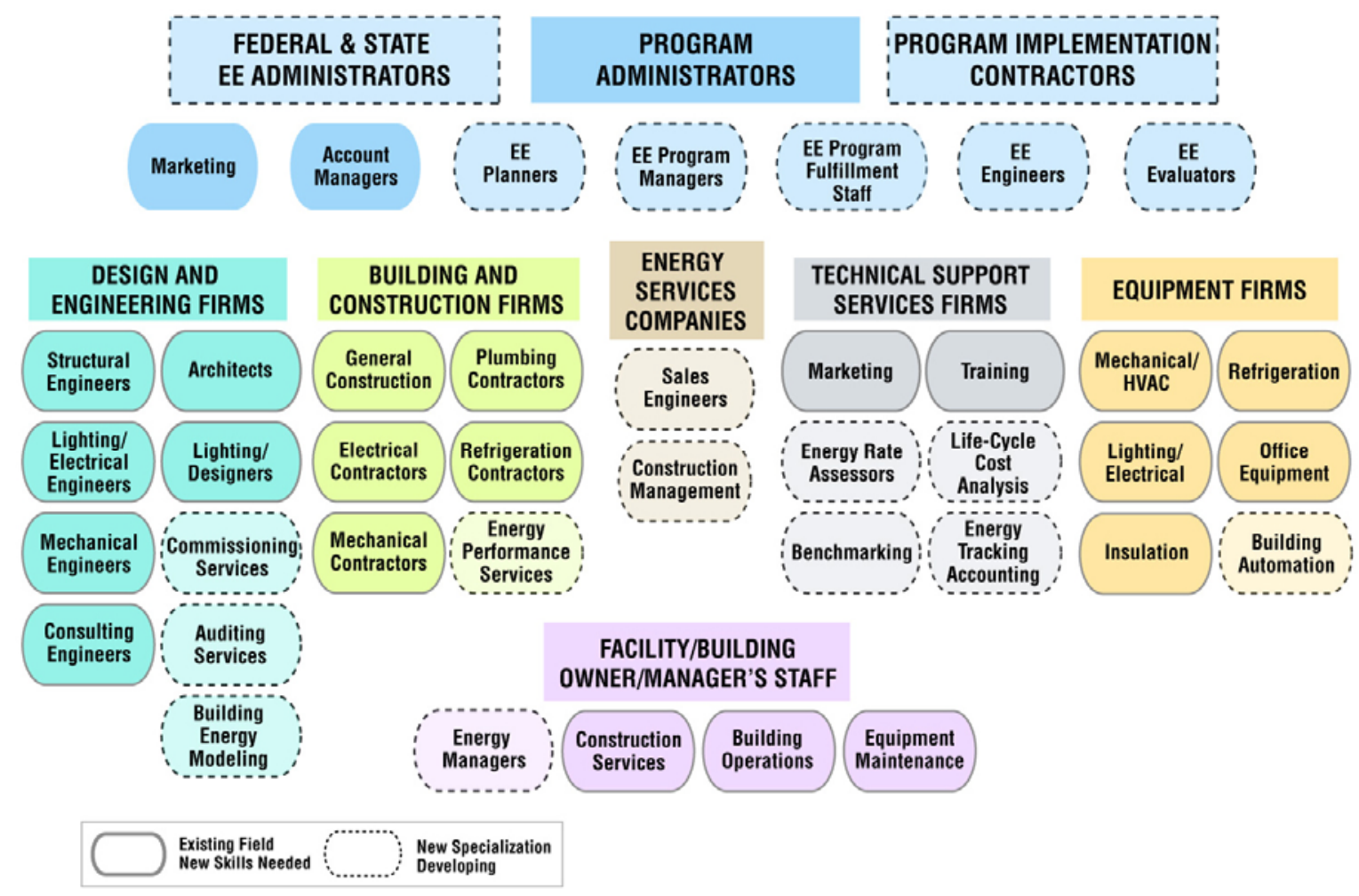

Figure 5: Commercial-Institutional Energy Efficiency Services Sector

- The proportion of lighter dotted-line boxes in Figure 5, Figure 6 and Figure 7 also illustrates the emergence of a variety of new skill-sets and new professional categories specific to energy efficiency that involve tasks and activities that were not commonly addressed within the traditional building design, construction, equipment, and operations professions and trades. These new job occupations include:

o Auditing to identify energy savings opportunities;

o Energy modeling to analyze the savings opportunities;

o Commissioning to ensure equipment is installed and operated as designed;

o Training in home energy efficiency retrofit services;

o Installation of new equipment such as industrial energy management and building automation systems;

o Various types of analysis services including benchmarking, life-cycle cost assessment, and energy rate analysis; and

o Staff positions among the various types of program administrators, program implementation contractors and program support contractors; ${ }^{21}$

\footnotetext{
${ }^{20}$ Program administrators also contribute to WAP funds. We tally the workforce associated with these ratepayer WAP funds as part of the program administrator workforce and exclude them from our tally of the WAP workforce estimates.
} 


\section{o Home performance contractors (see Figure 6). ${ }^{22}$}

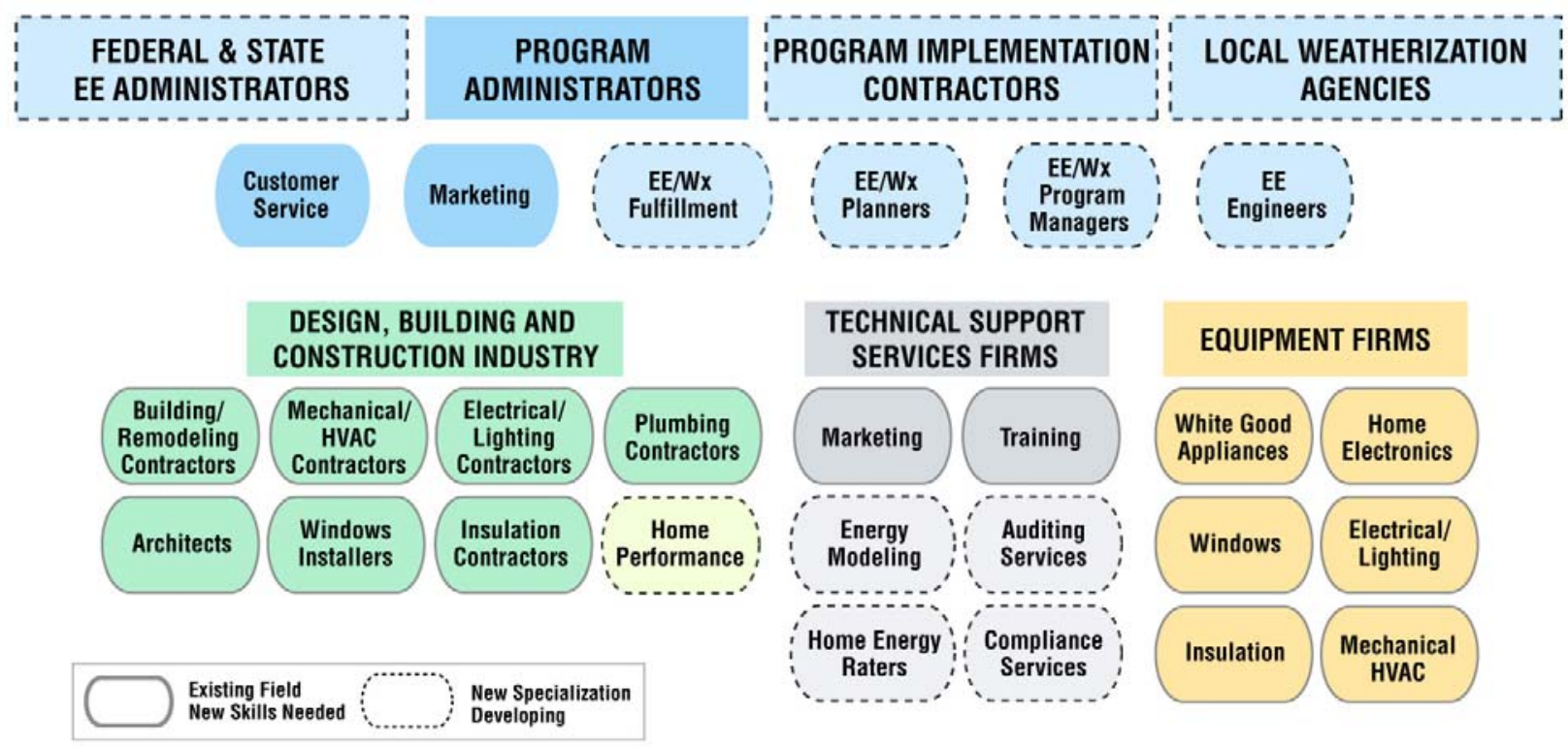

Figure 6: Residential Energy Efficiency Services Sector

- Program implementation contractors are often responsible for the day-to-day management of energy efficiency programs and include consulting firms that provide energy efficiency program design and planning, program implementation, and program monitoring, verification, and evaluation services. Program implementation contractors have the ability to scale up or down quickly - for individual programs or for large programmatic efforts - and typically work for multiple program administrators. Program implementation contractors often have teams of specialists in various program areas that can work part- or full-time as programs ramp up, thus providing additional flexibility to program administrators in managing work load and staffing.

- Organizations that are program administrators and program implementation contractors typically include firms that involve many occupational specialties, which are illustrated by the oval boxes in the second row from the top in Figure 5, Figure 6 and Figure 7 by the oval boxes in the second row from the top of each figure. These job specialties include marketing and customer service managers; jobs now devoted to energy efficiency but that use the same basic tools-of-the-trade of non-EESS marketers and managers (the darker-colored oval boxes with solid outlines). Firm types that involve specialties involving skills or tasks unique to energy efficiency program implementation are lightercolored with dotted outlines and include energy efficiency planners, evaluators, program

\footnotetext{
${ }^{21}$ The staffs of these organizations plan, design, manage, and evaluate energy efficiency programs and in some cases are the field crews that install and/or inspect energy efficient projects.

${ }^{22}$ See E. Redman, "Report on the Home Performance Industry Perspective on Training and Workforce Development” (May, 2010), for more discussion of the emerging home performance industry: http://www.hprcenter.org/publications/green_jobs_in_the_residential_energy_efficiency_industry.pdf.
} 
managers, engineers, and program fulfillment staff. Note that these job specialties vary somewhat across the three customer markets.

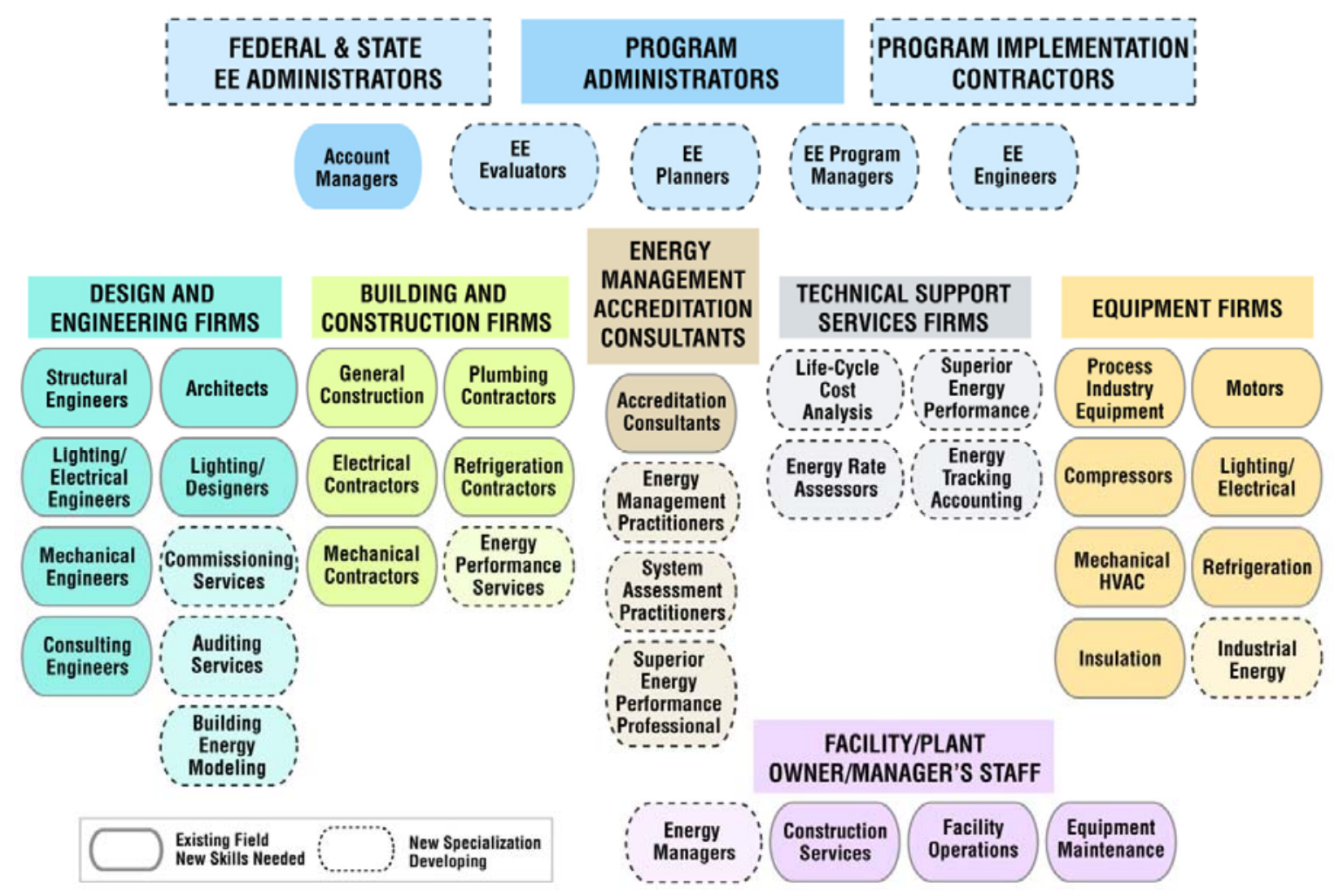

Figure 7: Industrial Energy Efficiency Services Sector

- Program administrators typically augment their staff through contracts with individuals and small firms with energy efficiency specialties, which we classify as "program support contractors." These contractors are the primary providers of the new and emerging activities shown in the lighter-colored dotted-outline boxes in the second tier of the diagrams (see Technical Support Services). ${ }^{23}$ They provide such specialty services as reviewing project energy savings calculations and estimates, calculating customer incentives, running cost-effectiveness models, conducting field inspections, assisting with program planning, and providing regulatory support. These firms have the ability to add or reduce staffing capability quickly and often have experienced professionals who have worked for program administrators, thus, providing additional flexibility to program administrators in managing work load and staffing.

- The third tier row of Figure 5, Figure 6 and Figure 7 includes firms that provide more specialized services in the areas of design and engineering, building and construction,

${ }^{23}$ Program Support Contractors can also include engineers, architects, economists, and energy efficiency generalists who serve as business and management consultants. 
ESCOs (in the institutional/commercial market), energy management accreditation consultants (in the industrial market), technical support contractors, and equipment manufacturers. For these companies, energy efficiency-related jobs are created due to several factors: business-as-usual market demand for energy-saving equipment and services (i.e. not driven by government policy or ratepayer funding) and jobs that result from supporting EE policies (e.g., building codes that require certain construction standards, industrial standards for energy efficiency management (ISO 50001) and system assessment (ANSI-ASME)). [McKane et al. 2008; McKane et al. 2007] Jobs are also created through funding (i.e., financial incentives for implementing energy efficiency projects) received from programs offered by program administrators.

- Program administrators and program implementation contractors also offer resources often financial incentives, but sometimes training, technical assistance, product development expertise, or other information-based resources - that support the components of EESS found in the third tier in other ways. In both the commercial and institutional (Figure 5) and industrial markets (Figure 7), program administrators provide financial incentives to firms (design and engineering companies, building and construction firms, technical support services or equipment vendors) who deal directly with customers, or to the customers themselves who seek these services from the market. For the residential sector (Figure 6), the program administrators or local weatherization agencies facilitate the installation of energy-efficient products and services. Program implementation contractors often use design and engineering and/or construction firms to facilitate the deployment of products and services. Technical services jobs that support residential energy efficiency have also emerged such as auditing and energy modeling.

It is clear from the market characterization diagrams that the EESS is a multi-disciplinary sector that addresses the design and construction of homes and buildings, and the installation, use, and maintenance of high-efficiency equipment and technologies in homes, buildings, and industrial processes. The EESS includes engineers, designers, economists, marketers, and trades people. At present, it does not constitute an independent industry, since the activities of the EESS, rather than being new efforts, typically consist of a shift from standard practice to a more energy-efficient approach to the design, construction, equipping, and operating of buildings. Hence, this is our rationale for using the term "energy efficiency services sector" rather than "energy efficiency industry."

Finally, these market characterization diagrams also highlight the point that there is potentially a high degree of substitution in the EESS for many services and products that are similar to existing services in the building and construction industry (as illustrated by the solid boxes). The focus of the EESS is on the most energy-efficient product or service. These products and services exist in the market place and
The Energy Efficiency Services Sector does not constitute an independent industry, since the activities of the EESS typically consist of a shift from standard practice to a more energyefficient approach to the design, construction, equipping and operating of buildings. 
are, through the efforts of tax payer- and ratepayer-funded programs, supported in order to gain an increased share of the market, displacing less efficient products and services. ${ }^{24}$ Thus, many jobs in the EESS are not new jobs, but rather jobs that are evolving to improve the energy efficiency of the product or service provided. To recall the comment by Hendricks (2009) on green jobs: there are created jobs, transformed jobs, and retained jobs. Those in the light colored boxes are created. Those in the solid boxes are retained or transformed. A significant expansion of the EESS will necessarily involve the creation of a transformed building and construction industry, which will be at the core of the EESS.

\subsection{Job Categories and Roles within EESS Organizations}

We are also interested in characterizing how organizations involved in the EESS establish and utilize various job categories to deliver services. In this section, we draw from our survey responses to describe the job categories and roles found in program administrator and program implementation contractor organizations,

Growth of the Energy Efficiency
Services Sector will involve
transformation of the
construction industry, which
will be core to the EESS.
ESCOs, low-income weatherization programs, and the design, engineering, building, and construction industries. Prior to fielding the surveys, we developed job categories for each type of organization in the EESS. We asked respondents to identify their staffing mix across the various categories and describe the key skill sets and training for major occupations.

\subsubsection{Program Administrators, program implementation contractors, and program support contractors}

The job categories that make up program administrator, program implementation contractor, and program support contractor organizations range from management to planning, implementation (e.g., technical services, training, marketing), and evaluation (see Table 5).

Table 5: Job Categories: Program Administrators, Program Implementation Contractors and Program Support Contractors ${ }^{25}$

\begin{tabular}{|c|c|}
\hline Job category & People in this category ... \\
\hline Senior management & $\begin{array}{l}\text {..provide the senior level of management to the EE organization. In the } \\
\text { case of a large utility or private firm this is the EE department; in the case } \\
\text { of smaller organizations that focus solely on energy efficiency this could be } \\
\text { the senior management of the entire organization. }\end{array}$ \\
\hline $\begin{array}{l}\text { Program planning, design, and } \\
\text { budgeting }\end{array}$ & $\begin{array}{l}\text {...conduct activities that get an EE program into the overall program } \\
\text { portfolio of an organization. }\end{array}$ \\
\hline $\begin{array}{l}\text { Program management and } \\
\text { administration }\end{array}$ & $\begin{array}{l}\text {...provide leadership for a specific program such as a commercial lighting } \\
\text { or new construction program. }\end{array}$ \\
\hline Program technical services and field & ...provide technical services in the field such as auditors, installers, and \\
\hline
\end{tabular}

\footnotetext{
${ }^{24}$ There are always new entrants of high-efficiency items to the market. Some public policy programs, especially those of the federal government, provide support for R\&D and commercialization of new technologies.

${ }^{25}$ For some of these job categories there is more than one occupation.
} 


\begin{tabular}{|c|c|}
\hline staff & verifiers. \\
\hline Program training and marketing & $\begin{array}{l}\text {... work with trade allies and others to train them in new programs and } \\
\text { market the EE programs. }\end{array}$ \\
\hline $\begin{array}{l}\text { Program support and incentive } \\
\text { processing }\end{array}$ & $\begin{array}{l}\text {...provide overall administrative support to EE programs, including } \\
\text { incentive processing and data entry. }\end{array}$ \\
\hline $\begin{array}{l}\text { Program evaluation and market } \\
\text { assessment }\end{array}$ & $\begin{array}{l}\text {...conduct research aimed at improving the design and implementation of } \\
\text { EE programs and assessing their impacts on end use and product markets. }\end{array}$ \\
\hline
\end{tabular}

The job categories are similar among program administrators and program implementation contractors, although we found some differences in staffing patterns and organization among these two types of firms (Figure 8). For example, we found that program implementation contractors have more staff in their organization that provide technical services and field support (37\% vs. 22\%), program support and incentive processing, and program evaluation and market assessment (12 vs. 4\%) compared to program administrators.

Program implementation contractor organizations also have relatively more senior management staff than do program administrators (12\% vs. $7 \%$ ). This is likely because utilities have fewer managers directly assigned to energy efficiency efforts, which are typically a department within a large corporation rather than an entire business unit or company as with program implementation contractors. In contrast, program administrators have more positions for training and marketing, program planning and design, and program management and administration, reflecting their active role in trying to plan and design programs to influence market response.

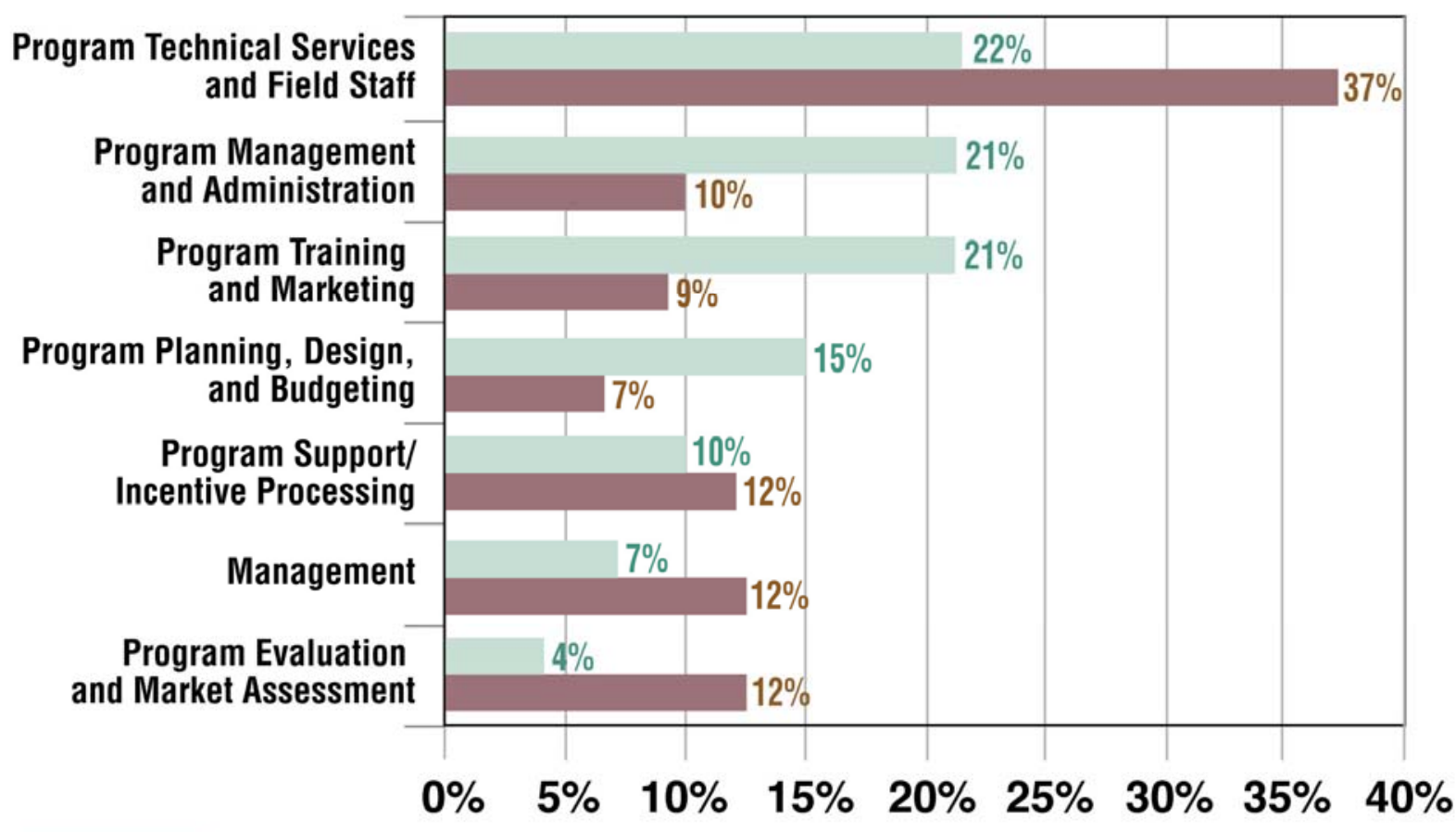

Program Administrator $(n=38)$

Program Implementation Contractor $(n=34)$ 


\section{Figure 8: Distribution of Program Administrators and Program Implementation Contractors Workforce by Job Category}

\subsubsection{Energy Service Companies}

Energy service companies (ESCOs) develop and implement turnkey, comprehensive energy efficiency projects and provide other value-added services; ESCOs offer performance-based contracts (i.e., contracts that tie the compensation of the ESCO to the energy savings generated by the project) as a significant part of their business. About $80 \%$ of the ESCO market activity is targeted to the public/institutional market and their projects tend to be relatively large and complex (e.g., the typical ESCO project size is about \$1.7M for institutional customers; see Goldman et al. 2005). Key job categories include sales and marketing, project design and engineering, construction management and project maintenance and savings verification (see Table 6).

Table 6: Job Categories in ESCO Organizations ${ }^{26}$

\begin{tabular}{|c|c|}
\hline Job category & People in this category ... \\
\hline Senior management & ...provide the senior level of management to the organization. \\
\hline Sales and marketing & $\begin{array}{l}\text {...staff develop business leads and projects; work with customers to } \\
\text { make project happen; participate in investment-grade audits. }\end{array}$ \\
\hline Project design and engineering & $\begin{array}{l}\text {...conduct investment-grade audits; design and engineer projects, } \\
\text { develop project costs and budgets, develop construction drawings and } \\
\text { specifications. }\end{array}$ \\
\hline Construction management & $\begin{array}{l}\text {..provide leadership on site for installations and retrofits, ensure } \\
\text { projects are completed on budget and to design requirements. }\end{array}$ \\
\hline $\begin{array}{l}\text { Project maintenance and savings } \\
\text { verification }\end{array}$ & $\begin{array}{l}\text {..oversee project-related operations and maintenance after project is } \\
\text { accepted by owner; gather field and billing data to verify savings; } \\
\text { prepare reports on project savings and performance. }\end{array}$ \\
\hline
\end{tabular}

We asked ESCOs about their major functional areas for staffing; staff activity within ESCO organizations is dominated by sales and marketing (28\%) and project design and construction management (44\%) [see Figure 9]. Like program administrators, ESCOs tend to contract installation activities to the building and construction industry (e.g., HVAC and lighting contractors). Therefore, ESCO staff typically does not include these field positions.

\footnotetext{
${ }^{26}$ For some of these job categories there is more than one occupation.
} 


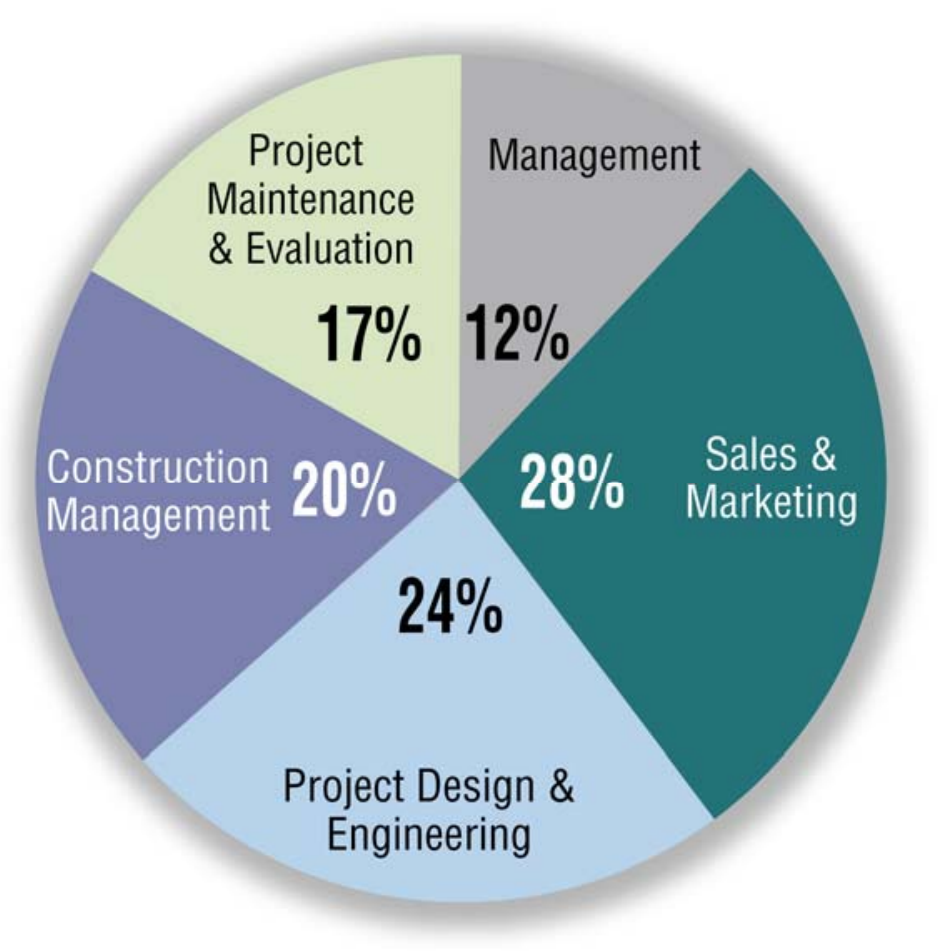

\section{Figure 9: Organizational Functions within ESCO Organizations}

The allocation of work between program administrators, program implementation contractors, and ESCOs leads to different needs for staff skills. In terms of staffing, the respondents for ESCO organizations reported that their staffs are dominated by engineers (60\%) (see Table 7). While both program administrators and program implementation contractors have engineers on staff, respondents reported that staff engineers comprise a larger share of the total organization for program implementation contractors (26\%) compared to program administrators (17\%).

Table 7: Role of engineers in energy efficiency organizations

\begin{tabular}{|l|r|}
\hline Organization type & $\begin{array}{r}\text { Engineers as percent of } \\
\text { total staff (est.) }\end{array}$ \\
\hline Program Administrators & $17 \%$ \\
\hline $\begin{array}{l}\text { Program Implementation } \\
\text { Contractors }\end{array}$ & $26 \%$ \\
\hline ESCOs & $60 \%$ \\
\hline
\end{tabular}

\subsubsection{Low-Income Weatherization}

The distribution of jobs is somewhat different among organizations that provide energy efficiency services in the residential market. For example, job categories in organizations that manage and deliver weatherization services targeted to low-income customers as part of federal and state weatherization programs are shown in Table 8. The program planning and design 
function is conducted by designated state and federal agencies (e.g., DOE) and the local weatherization agency staff act in a manner similar to the management and administrative staff of program administrators and program implementation contractors. Unlike administrators of ratepayer-funded programs, local weatherization agencies use a substantial amount of in-house field and technical staff: crew leaders and crew members do audits and installations of weatherization measures in low-income households.

\section{Table 8: Job Categories in Low-Income Weatherization Programs ${ }^{27}$}

\begin{tabular}{|l|l||}
\hline \hline Job category & People in this category ... \\
\hline \hline State and national program staff & $\begin{array}{l}\text {...provide overall management and administration of weatherization funds, } \\
\text { coordinate large scale training efforts, and stay abreast of technological } \\
\text { developments in the field. }\end{array}$ \\
\hline $\begin{array}{l}\text { Local program management and } \\
\text { administration }\end{array}$ & $\begin{array}{l}\text {...account for local program resources, coordinate local training efforts, and } \\
\text { manage multiple crews in a defined region. }\end{array}$ \\
\hline Crew leaders & ...oversee a crew that implements weatherization activities in homes. \\
\hline Crew members & $\begin{array}{l}\text {..audit, weatherize (e.g., insulate building shell, windows), and install } \\
\text { high-efficiency equipment in homes making them more energy-efficient. }\end{array}$ \\
\hline \hline
\end{tabular}

Source: Adams 2009.

Engineering skills are much less in demand for residential and low-income weatherization programs. Though engineering technician skills are desirable for certain functions associated with building analysis and program design, engineering skills in the residential sectors primarily support the development of tools for technicians and contractors.

\subsubsection{Design, Engineering, and Building and Construction Industries}

The professionals, contractors, and trades people working in the design, engineering, and building and construction industries support and implement energy efficiency projects that are managed and partially funded by various program administrators, projects developed by ESCOs, and projects that occur as a result of their own market-driven business activities (see Table 9). ${ }^{28}$ New job categories related specifically to energy efficiency services are being created in the design, engineering, and building and construction industry; examples include auditors, commissioning agents, and compliance services.

The building and construction industry provides the largest share of jobs in the EESS (see Section 4). However, in order to effectively provide energyefficient solutions, the services provided by architects, electricians, mechanical contractors, insulation contractors, and other standard occupations in the building and construction

In order to provide the needed energy efficiency solutions, standard occupations in the building and construction industry will need to be transformed through energy efficiency training-by retraining current workers and adding energy efficiency to existing design, engineering and construction education programs. industry need to be transformed and enhanced through energy efficiency training. This

\footnotetext{
${ }^{27}$ For some of these job categories there is more than one occupation

${ }^{28}$ In some states, local weatherization agencies increasingly rely on contractors to install selected equipment measures as a way to scale up the workforce as needed.
} 
transformation of occupations will come about through retraining current industry members and by incorporating energy efficiency training in the education and training programs that already exist for design and engineering professionals, and the rest of the building and construction industry.

\section{Table 9: Job Categories in Design, Engineering and Building/Construction Firms that Provide Energy Efficiency Services}

\begin{tabular}{|l|l|}
\hline Job category & People in this category ... \\
\hline Architectural firms & ....design buildings, develop drawings and specifications for construction. \\
\hline Engineering firms & $\begin{array}{l}\text {....design energy using systems for new and existing buildings; prepare } \\
\text { drawings and specifications for construction; develop software and analysis } \\
\text { tools for building modeling and simulation of energy consumption; and } \\
\text { commission new buildings and high-efficiency projects. }\end{array}$ \\
\hline $\begin{array}{l}\text { General contractors, builders, and } \\
\text { remodeling firms }\end{array}$ & $\begin{array}{l}\text {....create the team that constructs or renovates the building, solicits bids } \\
\text { from equipment contractors, and structural and construction specialties, and } \\
\text { coordinate with design team and owners. }\end{array}$ \\
\hline $\begin{array}{l}\text { Equipment contractors and vendors } \\
\text { (e.g., mechanical, electrical, lighting, } \\
\text { and refrigeration) }\end{array}$ & $\begin{array}{l}\text {...install specified products, systems, and equipment consistent with design } \\
\text { specifications }\end{array}$ \\
\hline $\begin{array}{l}\text { Building envelope contractors (e.g., } \\
\text { insulation, windows) }\end{array}$ & ...install specified products consistent with design specifications \\
\hline
\end{tabular}




\section{EESS Workforce Size: Current and Projected}

In this chapter, we present our estimates of the aggregate size of the current EESS workforce as well as projections of the EESS workforce in the near and longer term (i.e., 2010, 2015, and 2020) under low and high energy efficiency spending scenarios. Results are expressed in terms of the total number of person-years of employment (PYE). Our estimates of EESS workforce size are driven by two key factors: (1) estimated EESS spending and (2) person-years of employment per \$1 million (PYE/\$1M) of EESS activity spending. We then describe and discuss our bottom-up approach that was used to develop estimates of future energy efficiency spending/revenues and direct employment from EESS activity for major programmatic areas (e.g., ratepayer-funded EE, state/federal energy efficiency programs, low income weatherization, ARRA funds) and market-driven activities (e.g., ESCOs, insulation). See Appendix C for a detailed discussion of data and assumptions used to derive these workforce and spending estimates.

\subsection{Energy Efficiency Services Sector: National Spending}

We estimate that 2008 spending is just over \$18 billion in the U.S. EESS (see Figure 10); spending is forecasted to increase more than four-fold, to over $\$ 80$ billion in 2020 under the high growth scenario. This spending is the result of activity in the various sub-sectors (ARRA funds for energy efficiency, low-income weatherization, ratepayer-funded energy efficiency programs, ESCO revenues, and spending in building and mechanical insulation markets).

As summarized in Figure 10, in 2008 spending in the building and mechanical insulation markets constituted about 39\% of spending in the EESS. ESCO revenues represented about $27 \%$ of EESS spending and ratepayer-funded energy efficiency programs constituted about 30\% of EESS spending. 


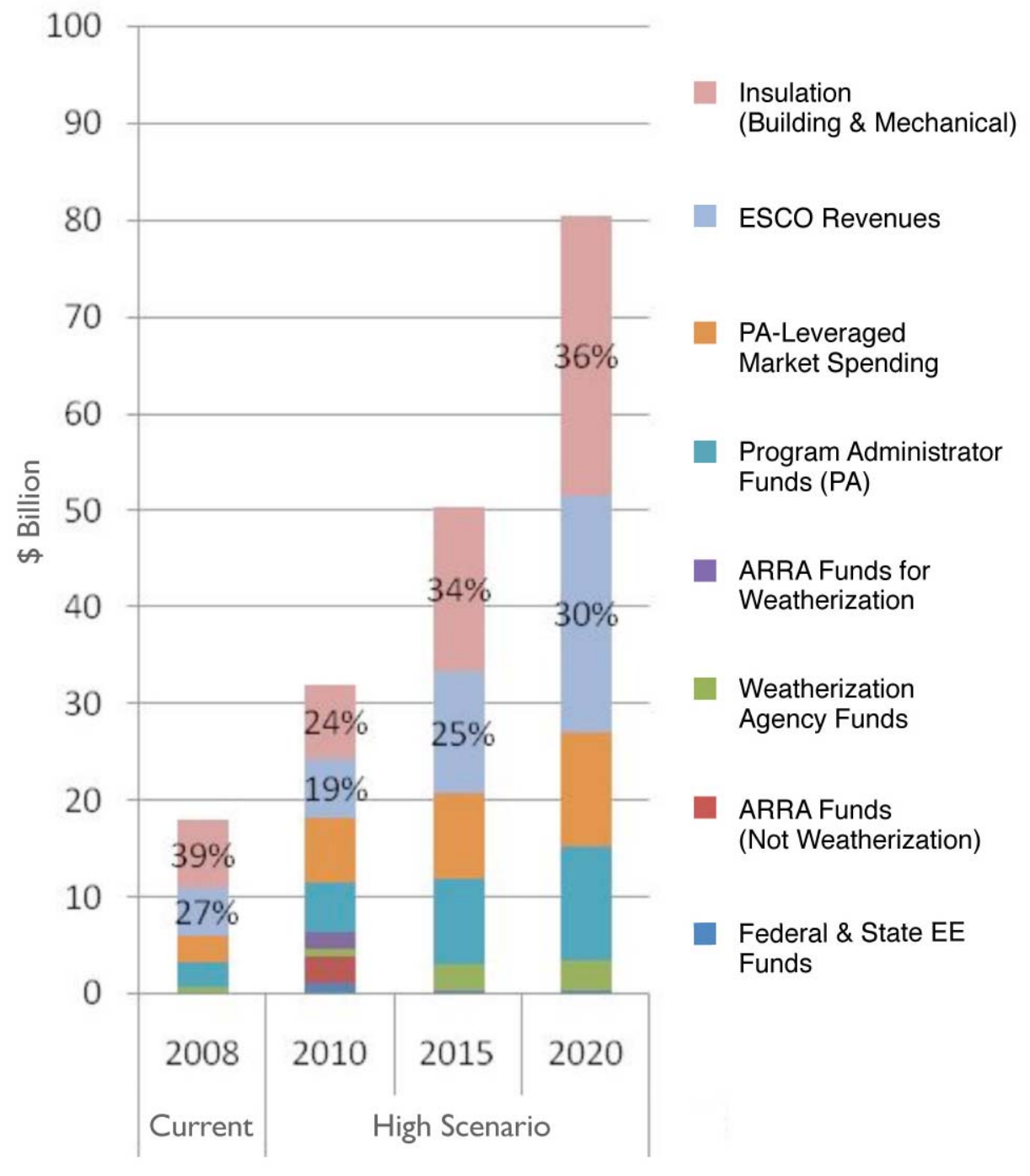

Figure 10: Current and Projected Spending in the EESS: High Growth Scenario

Figure 11 gives our forecast under the low-growth scenario for spending on EESS activity. We estimate that spending will double by 2020 to $\sim 37.1$ billion under the low growth scenario. 


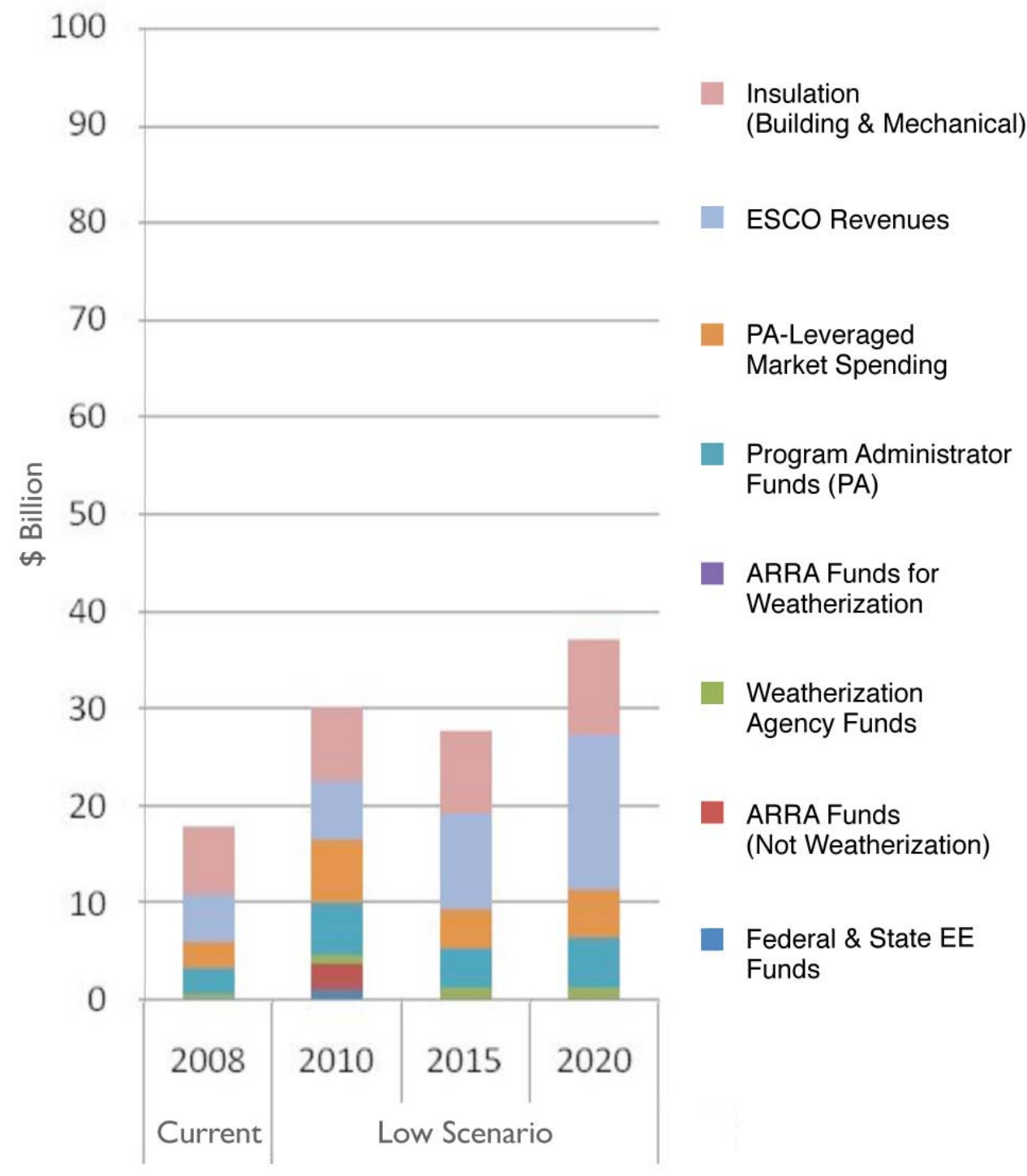

Figure 11: Current and Projected Spending in the EESS: Low Growth Scenario

\subsection{Total EESS Workforce}

Figure 12 and Figure 13 provide a high-level summary of our estimates of current and projected workforce size (expressed both in terms of person-years of employment and estimated number of individuals involved in the EESS) under the high efficiency spending scenario. The stacked bar graphs in each figure show estimated PYE for major energy efficiency program areas or marketdriven activity: (1) Ratepayer-funded energy efficiency programs includes program administrators, program implementation contractors, program support contractors, and building/construction industry employment induced by ratepayer-funded energy efficiency spending, (2) Low-income weatherization, (3) Other energy efficiency programs funded under the American Reinvestment and Recovery Act (ARRA), (4) ESCO market activity, including 
contractor employment induced by ESCO projects, and (5) market activity among building and mechanical insulation contractors.

In 2008, the EESS workforce comprised about 114,000 PYE in newly created or transformed jobs (see Figure 12). Many employees in the EESS work part time or spend some fraction of their full-time job providing energy efficiency services. Figure 13 provides an illustrative sketch of total employment of individuals in the EESS. We estimate that 380,000 individuals were employed in EESS activities in 2008, or over three times the estimated EESS workforce in person-years of employment (see Appendix C.13 for details). ${ }^{29}$ We estimate that the building and construction industry workforce engaged in activities that impact the efficiency with which energy is used in buildings (e.g., building construction, home remodeling) was 4.2 million PYE in 2006 (Bureau of Labor Statistics 2006). ${ }^{30}$ Note that our estimate of the EESS workforce includes both professionals and trades people. However we approximated the trades' employment in the EESS by considering just the following sub-sectors: insulation and building and construction industry activity induced by ratepayer-funded energy efficiency and ESCO activities. Our estimated PYE for these groups is equivalent to over $2 \%$ of the broader building and construction industry workforce potentially engaged in energy efficiency.

\footnotetext{
${ }^{29}$ We derive this estimate of individuals by applying assumptions about the percent of time a typical worker spends doing energy efficiency-related work by category of employment. These assumptions range from one-eighth time on average for building and constructions trades people to full time for program administrators, program implementation contractors, federal and state efficiency administrators, and ESCO staff.

${ }^{30}$ We estimated the size of the building and construction industry most aligned with the EESS by identifying occupational categories (48 categories) in the most aligned industries (NAICS codes 2361, 2362, 2382, 2383, 2389, and 5413) and tallied how many PYE they represent. The Bureau of Labor Statistics reported data for 2006 and a forecast for 2016, from which we calculated an average growth rate to 2020.
} 


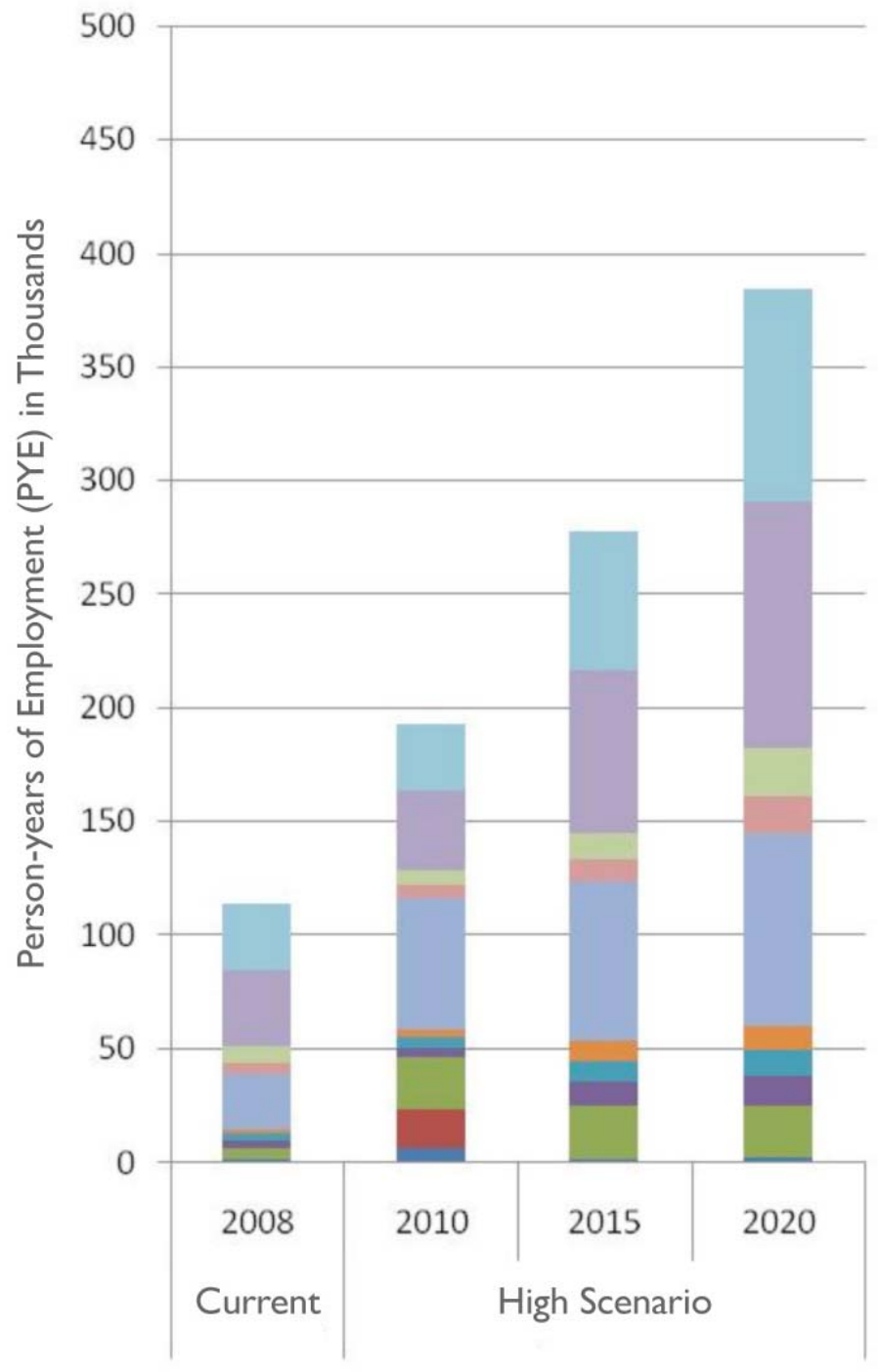

Mechanical Insulation

Building Envelope Insulation

Building and Construction Industry Induced by ESCO Activity

ESCO Staff

Building and Construction Industry Induced by PA Spending

Program Support Contractors

Ratepayerfunded

Program Implementation Programs Contractors

Program Administrators (PA)

Weatherization Agencies and Contractors

EE Staff Funded by ARRA Programs

Federal \& State EE Administrator Employees

Figure 12: Current and Projected Person-Years of Employment in the EESS: High Growth Spending Scenario

Ratepayer-funded energy efficiency efforts currently constitute about 30\% of estimated EESS person-years. This employment includes the staffs of program administrators, program implementation contractors, and program support contractors they hire, and the building and construction professionals and trades people who design and install the equipment that ratepayer funds subsidize. ESCO efforts constitute about 10\% of the total person-years, including ESCO staff and the contractors they hire among the building and construction industry. The weatherization assistance efforts of the federal and state governments constitute about $5 \%$ of the total EESS person-years. Finally, the professionals and trades people responsible for building envelope insulation and those responsible for mechanical insulation each comprise more than one quarter of the 2008 EESS person-years of employment. 


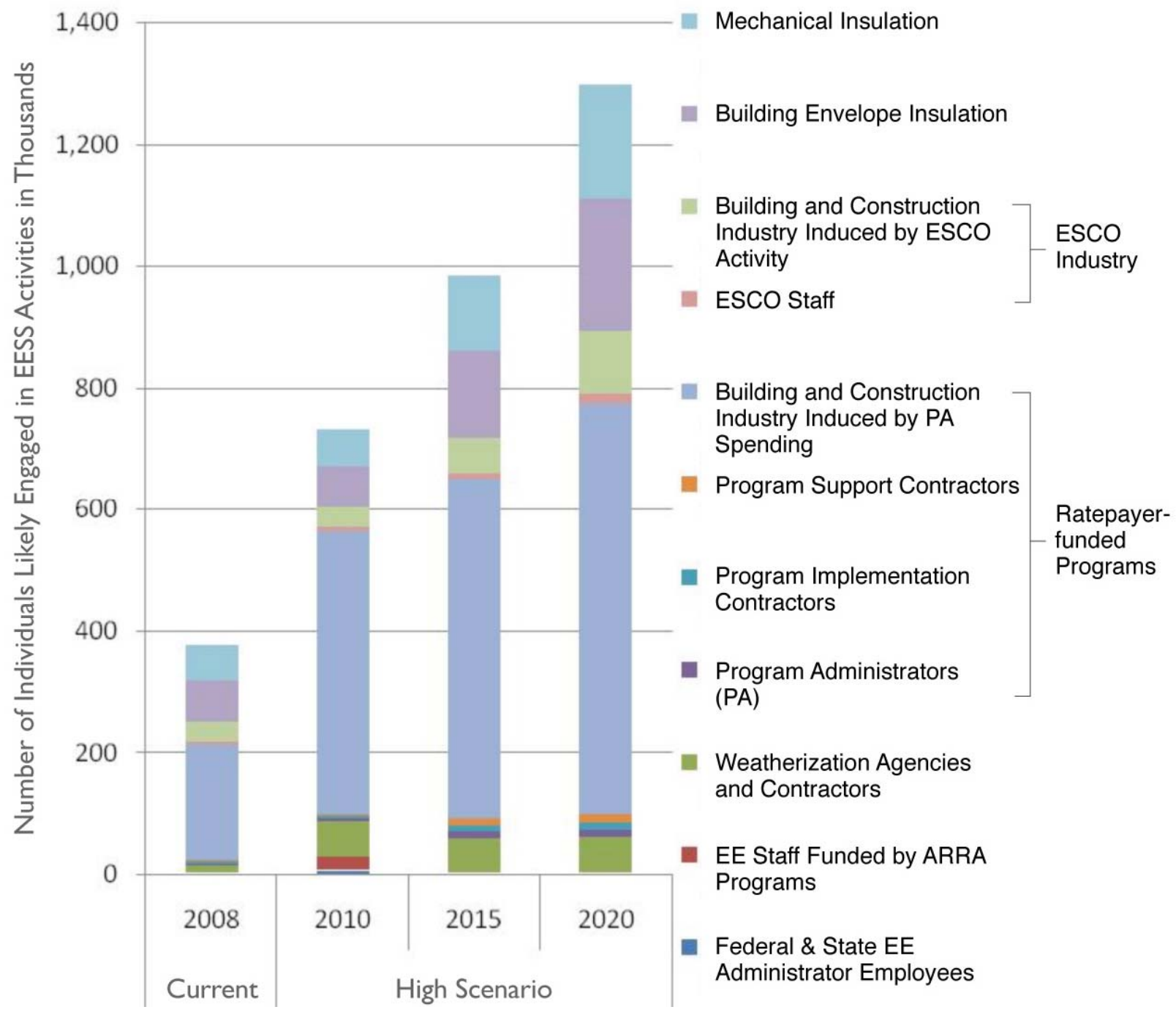

Figure 13: Illustrative Sketch of Number of Individuals Likely Engaged in EESS Activities

The workforce estimates presented here are in PYE and do not necessarily represent the number of individuals employed. Based on our interviews, we found that staffs of program

administrators, program implementation contractors, and ESCOs are likely to be employed fulltime or nearly full-time in energy efficiency; thus for these groups, the PYE provides a rough approximation of the number of individuals employed. This is not the case for the other groups. The building and construction trades people who support PA and ESCO activities conduct various types of work in their business, of which a fraction involves developing and installing high-efficiency measures and equipment. Weatherization assistance employs many part-time workers. Even the person-year counts for building and mechanical insulation likely understates the total number of individuals employed, as insulation may be just one aspect of the on-the-job activities of these trades people. For each of these groups (other than PA, PIC, and ESCOs), the number of individuals that are involved in energy efficiency projects and efforts could easily be three to five times the estimated person-years of employment. 
Figure 13 provides an illustrative sketch of total employment of individuals in the EESS. We estimate that 380,000 individuals likely are employed in EESS activities in 2008, or over three times the estimated EESS workforce PYE (see Appendix C.13 for details).

Figure 12 also depicts high growth scenarios to 2020 and suggests that the EESS may grow to just under 400,000 person-years of employment by 2020. We believe a high growth spending scenario is more likely than the low growth spending scenario due to political imperatives to implement policies that address energy security, global climate change, and job creation in activities that cannot be moved overseas. The Bureau of Labor Statistics (BLS) forecasts the workforce size of those occupations and trades potentially associated with energy efficiency to be almost five million in 2020 (Bureau of Labor Statistics 2007; see Appendix A.10). Thus, in the high growth scenario, by 2020 the EESS may comprise as much as $8 \%$ of the relevant building and construction industry. As many as 1.3 million individuals could be employed in EESS activities in 2020 under our high growth spending scenario (see Figure 13).

Our high growth scenario includes several key assumptions:

- A quick ramp-up by 2010, reflecting the commitment of ARRA funds to weatherization assistance and other energy efficiency programmatic activities.

- Significant spending increases on energy efficiency over the next dozen years resulting from governmental policy and market investment in efficiency.

We think it is possible, but unlikely, that fuel prices will decrease in real terms - reducing the impetus for market investment in efficiency - and that political support for efficiency initiatives will wane. We captured these possibilities in a low growth scenario that assumes future energy efficiency spending will mimic the past with spending growth rates that are consistent with historic trends in some subsectors or zero \% in real terms (i.e. spending increases at the rate of inflation) (see Figure 14).

Even under a low growth scenario, we estimate that the EESS will comprise over 200,000 PYE in 2020, or about twice the current level. (This level of activity might involve about 750,000 individuals.) By design, the ARRA provides funding for various programs (e.g. SEP, EEBCG) that if implemented effectively would represent a very ambitious ramp-up in energy efficiency activity. There is significant uncertainty as to how rapidly the ARRA funds can generate substantial employment. Given this uncertainty, our 2010 low-growth scenario depicts the EESS in the absence of ARRA, while our 2010 high-growth scenario assumes that energy efficiency programs supported by ARRA funds ramp up relatively quickly. 


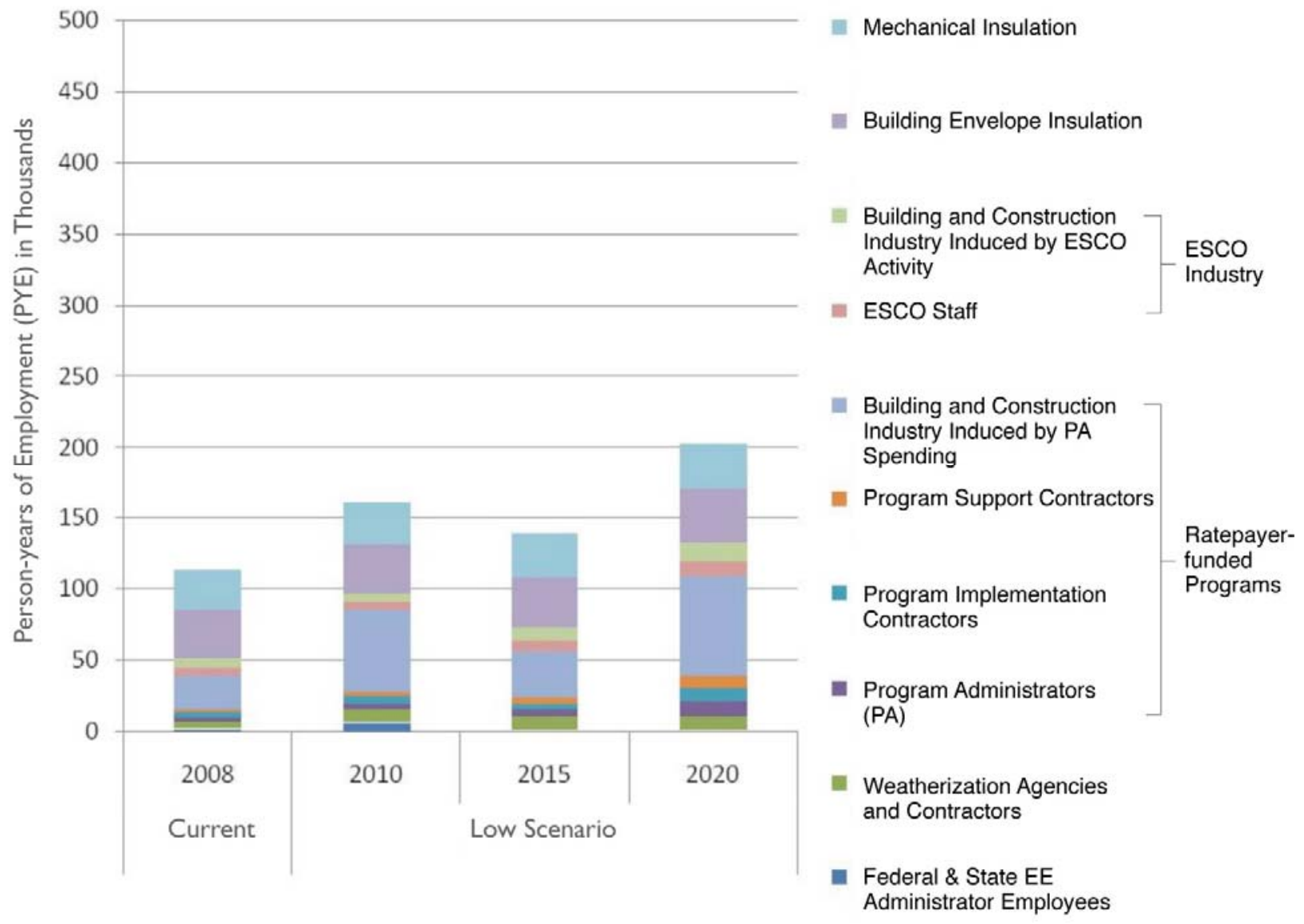

Figure 14: Current and Projected Person-Years of Employment in the EESS: Low Growth Scenario

Under either scenario, the EESS workforce will grow by a multiple of two to four between 2008 and 2020. This increase means people currently employed in the EESS will need additional energy efficiency-specific training to keep abreast of developments in the field and new people will need to be introduced to the sector and adequately trained to implement energy efficiency in a reliable and cost-effective manner.

One potential pitfall of rapidly expanding energy efficiency funding can be the attraction of "flyby-night” operations that are hungry for energy efficiency incentives and credits but are not properly trained to optimize efficiency. This could undermine the effectiveness of the efficiency investment. Poorly trained workers who do not deliver the promised energy savings could undermine the public commitment to, and market interest in, energy efficiency. Such a backlash might reduce the long-term employment prospects of people in the business of providing energy efficiency services.

In the next sections, we describe key drivers of our spending and employment projections for various sub-sectors of the EESS in greater detail. 


\subsection{Weatherization Assistance}

Federal and state policies provide weatherization assistance to low-income households. The U.S. DOE Office of Energy Efficiency and Renewable Energy (EERE) administer the Federal Weatherization Assistance Program (WAP). EERE works directly with the states, the District of Columbia, the U.S. Territories, and several Native American Tribal Governments. These governments contract with roughly 900 sub-grantees to deliver weatherization services. This consists of about 700 community action agencies and 200 units of local government and other non-profit organizations (Adams 2008). DOE EERE sets national guidelines of eligibility, establishes the technical merit of energy efficiency measures, documents energy savings, and provides technical training and assistance to weatherization service providers. The states make the rules and set eligibility standards for their residents, contract with weatherization agencies (typically community action agencies and community-based organizations), and monitor agency work to ensure quality.

The local weatherization agencies take applications from families in their service area, determine eligibility, and prioritize participants based on relative need; perform an energy audit and determine the most cost-effective weatherization measures for each dwelling; install those measures and inspect all work; and meet with family members to review the energy efficiency improvements. The funds can be used for energy efficiency measures, key health and safety improvements, and minor repairs that protect energy efficiency measures. Measures address the building envelope, the heating and cooling systems, electrical system, and electricity consuming appliances.

States can augment the DOE WAP funds by allocating up to 15\% of their LIHEAP Block Grant funds to weatherization, received from the U.S. Department of Health and Human Services (DHHS) or use Petroleum Violation Escrow (PVE) Account funds. ${ }^{31}$ In 2007, 44 states and the District of Columbia transferred LIHEAP funds into WAP; transfers varied from a low of \$200,000 in Nevada to a high of over \$35 million in New York (National Association for State Community Services Programs 2008). Some WAP offices also may access state-funded companion low-income programs and other public and private funding sources. The National Association for State Community Services Programs (NASCSP) reports these other funds have grown steadily since 1989 and totaled about \$200 million in 2007, or 30\% of total WAP monies (NASCSP 2008). Finally, many electric and gas utilities also provide weatherization services in ratepayer-funded energy efficiency programs targeted at low-income consumers, which we account for in our analysis of ratepayer-funded energy efficiency programs.

The average cost per home weatherized varies widely across states. Climate and housing characteristics influences the optimal level of weatherization activities; state differences also reflect state policies regarding eligible activities, equipment installation, and home repairs. Average cost per home weatherized ranged from about $\$ 2,000$ to over $\$ 8,000$, with a national average of just under $\$ 4,000$ (NASCSP 2008).

\footnotetext{
${ }^{31}$ In past years, states also have allocated Petroleum Violation Escrow Account (PVEA) funds to weatherization. States first had access to these funds in 1983, which resulted from settlements associated with violations of Federal oil pricing controls of 1973-1981. In 1997, PVEA funds comprised nearly 10\% of total WAP resources, yet by 2007 PVEA comprised only $\sim 0.5 \%$ of total funding ( $\sim 2 \mathrm{M}$ ) (NASCSP 2008).
} 


\subsubsection{Weatherization Assistance Budgets}

We developed both low and high funding scenarios for 2010 for two EESS sub-sectors (weatherization assistance and other ARRA energy efficiency programs) in order to illustrate the effects of ARRA funds.

In program year (PY) 2007, DOE funding for WAP totaled \$204 million; LIHEAP funds administered by WAP totaled \$256 million; and PVE funds totaled \$2 million (NASCSP 2008). We estimate that there was an additional \$66 million of other funding for low-income weatherization (that is non-DOE, non-LIHEAP) after accounting for the Consortium for Energy Efficiency (CEE) estimates of budgets for low-income energy efficiency programs funded by utility ratepayers (CEE 2008). ${ }^{32}$ This yields a total PY2007 budget of almost $\$ 530$ million for low-income weatherization.

Our low growth scenario for weatherization assistance in 2010 uses the FY 2009 DOE WAP appropriation of $\$ 450$ million, the LIHEAP FY 2009 transfers for weatherization of $\$ 400$ million, and other funding for weatherization at the inflation-adjusted 2008 value (see Figure 15). At an average cost of $\$ 4,000$ per home, about 230,000 homes can be weatherized with a total budget of about $\$ 920$ million. Our high scenario assumes that one-third of the ARRA appropriation for weatherization assistance of \$5 billion (i.e., \$1.66B) is spent in 2010 in addition to the funding assumptions of the low scenario. At $\$ 4,000$ per home, about 646,000 homes can be weatherized with a total budget of about $\$ 2.6$ billion. The ARRA legislation increases the cap on spending for a single home to $\$ 6,500$.

Our low scenarios for 2015 and 2020 for DOE funding of WAP assume the number of houses weatherized each year will be $50 \%$ more than in 2008, on the assumption that the increased weatherization capacity stimulated by ARRA will persist to some extent. We forecasted DOE WAP funding to reflect this increase in activity (and inflation). For LIHEAP and other funding sources, we assumed 2008 funding levels, escalated for inflation. We assumed the same average cost per house of $\$ 4,000$ (in constant 2008 dollars).

Our high scenarios for 2015 and 2020 assume federal policymakers commit to a high level of low-income weatherization assistance. ${ }^{33}$ We assumed that DOE WAP spending in 2015 and 2020 maintains much of the impetus from the ARRA and continues at roughly the magnitude achieved in 2010 (see Figure 15). For LIHEAP, we assumed 2010 funding levels (PY 2009), because the latest LIHEAP budget appropriation for WAP represents an infusion of money. We hold “other” funding constant in real terms at its 2008 level. At an average cost of \$4,000 per

\footnotetext{
32 We subtracted CEE (2008) estimates of ratepayer-funded low income budgets from the NASCSP estimates of "other" funding, leaving \$66 million in other funding in 2007. The low income weatherization assistance effort leverages a small amount of private-sector spending for energy efficiency (e.g., building owners decide to use their own funds to buy down the cost of measures that otherwise would not pass the implementer's cost-effectiveness criteria). The NASCSP study includes leveraged private-sector money in its estimates of "other" funds.

${ }^{33}$ It is important to note that our estimated funding levels are higher because we assume that continued efforts to increase funding for weatherization will supplant the current Federal forecast.
} 
home (constant 2008 dollars), about 650,000 homes would be weatherized per year in the high growth scenario. If the cost per home averages about $\$ 5000$, about 520,000 homes would be weatherized in the 2015 and 2020 high scenarios.

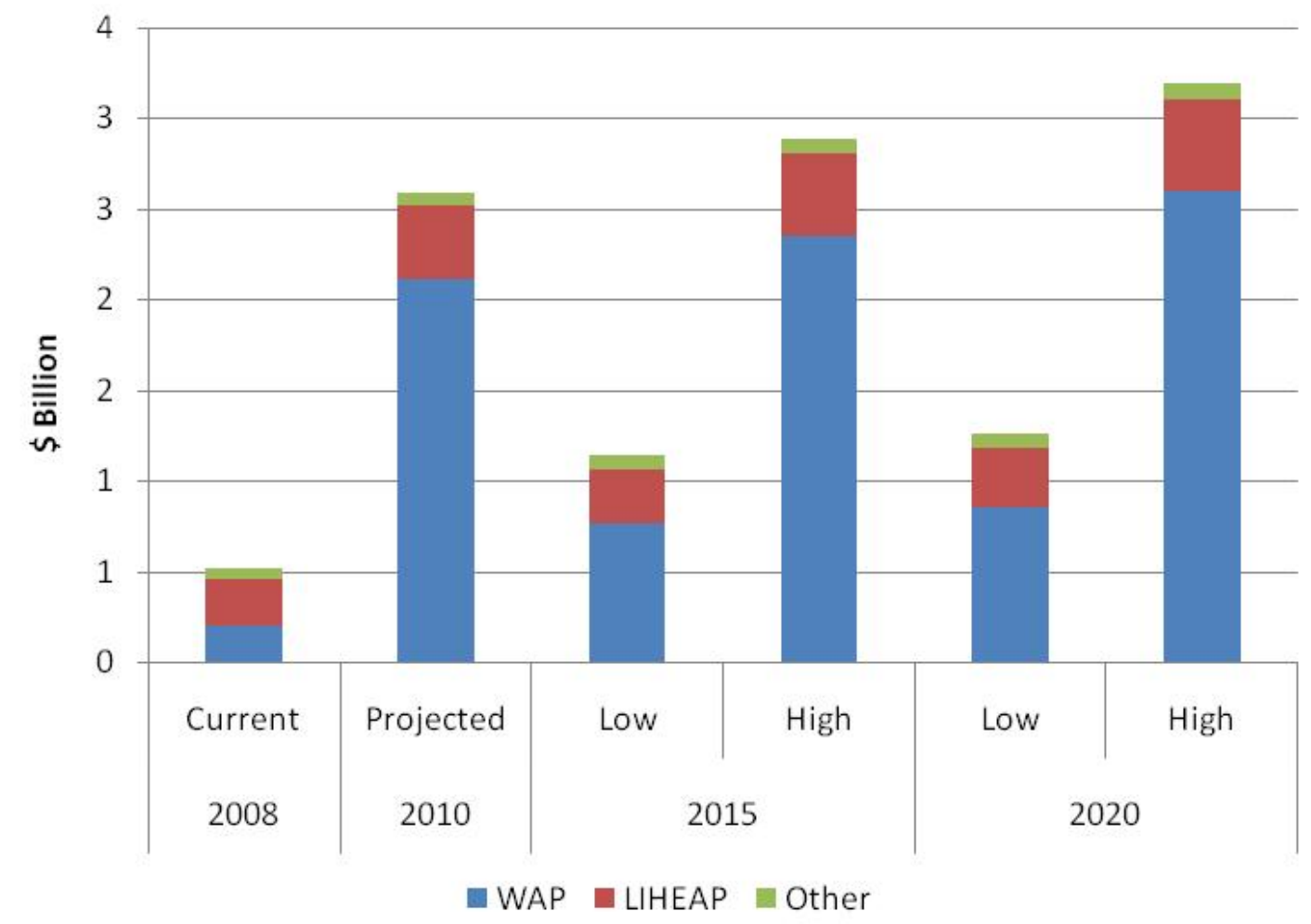

Figure 15: Projected Funding for Low-Income Weatherization Efforts

\subsubsection{Weatherization Assistance Workforce Estimates}

We relied on research conducted by New England Clean Energy Council (NECEC) in developing estimates of workforce jobs created by weatherization assistance spending. The study used a bottom-up methodology similar to our own and developed estimates of PYE per \$1 million in funding for low-income weatherization from analyses of detailed survey data (NECEC 2009). ${ }^{34}$ The study considered a mix of WAP activity - such as window replacement, equipment replacement, and home repairs - and the implications for staffing.

We analyzed this workforce data from Massachusetts and conducted sensitivity testing assuming different proportions of the various measures installed for the funding. From this sensitivity testing, we estimate a value of nine person-years of direct employment per \$1 million in WAP funding. Using this value, we estimate the weatherization assistance workforce at 4,676 full-time

\footnotetext{
34 The NECEC study conducted surveys of weatherization providers and estimated the number of WAP managers, auditors, and contractors needed to conduct various levels of activity.
} 
equivalent (FTE) workers in 2008 (excluding ratepayer-funded low -income activities, which are included in the program administrator analysis in Section 4.6).

Under the high spending scenario, we estimate that low-income weatherization will generate about 22,913 PYEs in 2010 and about 8,150 PYEs under the low spending scenario. Workforce estimates increase to about 9,200 PYE from weatherization assistance activities in 2015 and 2020 under the low-growth spending scenario and are about 23,000 PYE in the high spending scenario. Thus, our low-growth scenario represents a doubling of the weatherization workforce in 2020 compared to 2008 while our high scenarios represent an increase of nearly five-fold.

\subsection{Other ARRA-Funded Energy Efficiency Programs}

The ARRA of 2009 provided a large infusion of funding for energy efficiency (and renewable energy) programs administered by the Department of Energy: \$3.1 billion for the State Energy Program, \$3.2 billion for Energy Efficiency and Conservation Block grants, and \$300 million for energy-efficient appliances. We made assumptions about the proportion of these funds that would be allocated to energy efficiency in buildings (as opposed to efficiency in transportation, renewable energy, or other projects) and the proportion to be spent in 2010 vs. later years (see Appendix Table C-5). In the high-growth scenario, we also included ARRA funds allocated to energy efficiency projects conducted by the Department of Defense (\$3.69B), General Services Administration (\$4.5B), and the Department of Veterans Affairs (\$1B), and estimated the amount of these funds that would be spent in 2010 as well as PYE generated by these project activities.

In the high spending case, we assumed that about \$3.9B in ARRA funds will be spent on energy efficiency in 2010 through these programs. ${ }^{35}$ We also assumed that ARRA-funded energy efficiency programs would not continue through 2015 and 2020, because the ARRA legislation requires these funds to be spent within several years.

\subsubsection{Workforce Assumptions for ARRA-Funded Energy Efficiency Programs and Projects}

Because we did not have any primary information or survey data on workforce employment created by ARRA-funded energy efficiency programs, we decided to impute a value for ARRAfunded programs based on average PYE/\$1M in funding from all other EESS sub-sectors in our study. Using this method, we estimated that about six PYE are created per \$1 million of ARRA

investment. ${ }^{36}$ Using this approach, we estimated that about 23,200 PYE would be directly created by these ARRA-funded energy efficiency projects in 2010.

\footnotetext{
35 Several other government agencies received some ARRA funding for energy efficiency (e.g., Department of Housing and Urban Development), however, we did not attempt to estimate workforce employment effects for these agencies.

${ }^{36}$ We used total estimated spending in 2010 from ratepayer-funded energy efficiency programs, ESCOs, building trades, insulation, and weatherization assistance analyses divided by the total 2010 PYE estimated for these subsectors: 193,235 PYE / \$32 billion = 6 PYE on average per \$1 million.
} 


\subsection{Other Federal and State Energy Efficiency R\&D and Program Activities (Independent of ARRA and Weatherization)}

We examined the FY 2010 DOE EERE budget data and determined that energy efficiency programs comprised about $14 \%$ of the budget (exclusive of weatherization assistance), or \$243 million out of a total budget of $\$ 1,780$ million (see Appendix C). Such activity spans the DOE offices, national laboratories, and federal support for state energy offices. We derived low growth scenario funding estimates for 2010, 2015, and 2020 using the Federal budget forecasts through 2019 as published in the FY 2010 Federal Budget for DOE EERE, assuming energyefficiency-related activity continues at $14 \%$ of the total budget. For our high estimates, we assume DOE EERE funding will increase at 5\% per annum from 2008 onward.

\subsection{Ratepayer-Funded Energy Efficiency Programs}

Our estimates of staffing for program administrators and program implementation contractors are based on in-depth interviews conducted with 39 program administrators in the 11 case study states and 34 program implementation contractors who typically work in multiple states. Our sample captures virtually all program administrator activity within the 11 states and all program implementation contractors that have a national presence. The program administrators in the 11 states comprise roughly $70 \%$ of all 2008 ratepayer-funded energy efficiency (CEE 2008).

Program administrators estimated the size of their staffs on an FTE basis and provided estimates of projected staffing levels in the near term (i.e., 2010). On average, program administrators reported that their internal staffing levels would increase by $16 \%$ over the next several years.

Program implementation contractors also provided estimates of their current staffing levels on an FTE basis as well as expectations for growth in staff over the next several years. On average, program implementation contractors reported that they were planning to increase staffing levels by $48 \%$ in the near term. These results suggest that many program administrators are planning to rely heavily on program implementation contractors to enable them to quickly ramp up program activity, provide skills on a flexible basis, and enable utility program administrators to manage program growth if they face internal corporate-wide restrictions on staff sizes or staffing-tobudget ratios.

Using regression analysis, we found a strong relationship between program administrator spending and administrator staffing levels (see Appendix C.5); the estimated regression parameters were used to forecast PYEs for program administrators in 2015 and 2020 in the low and high spending scenarios.

Because program implementation contractors typically work in multiple states, we asked these respondents to estimate the proportion of their firms' activities in each of the 11 targeted states. We assumed that their workforce is proportional to their activity in that state in order to estimate their FTE staffing in the 11 states. We then aggregated the information provided by each program implementation contractor in order to estimate the total number of program implementation contractor staff employed by program administrators in these states. 
Using regression analysis, we found a strong relationship between program administrator spending and program implementation contractor staffing levels; the estimated regression parameters were used to forecast PYEs for program implementation contractors in 2015 and 2020 in the low and high spending scenarios.

In addition to program implementation contractors, many program administrators often hire program support contractors to expand their capabilities and augment their staffing resources in areas such as quality control, installation inspections, field inspections, and cost-effectiveness analysis of large custom projects. Through our survey with program administrators, it became apparent that these program support contractors often work for individual program managers and can be quite numerous in terms of number of entities and staffing. Our program administrator contacts typically were not able to provide detailed information on the number of program support contractors or how many staff they employed. However, in aggregate, many administrators indicated that program support contractors comprised a significant staffing resource in the programs they administered.

We used a case study approach to estimate PYE of staffing for program support contractors drawing upon our in-depth knowledge of management and staffing approaches among program administrators in California, Iowa, and New York from previous projects. ${ }^{37}$ We then extrapolated the quantitative findings from these three states to the other case study states in order to develop workforce staffing levels for program support contractors in the 11 states.

Figure 16 shows the estimated PYEs among program administrators, program implementation contractors, and program support contractors for the 11 targeted states. The figure uses a dottedoutline bar for the program support contractors to indicate that those estimates are less reliable than our estimates of program administrator and program implementation contractor employment.

\footnotetext{
${ }^{37}$ Program Administrators were unable to provide names of all their Program Support Contractors and given resource constraints, we opted for a different approach to estimate their workforce impacts.
} 


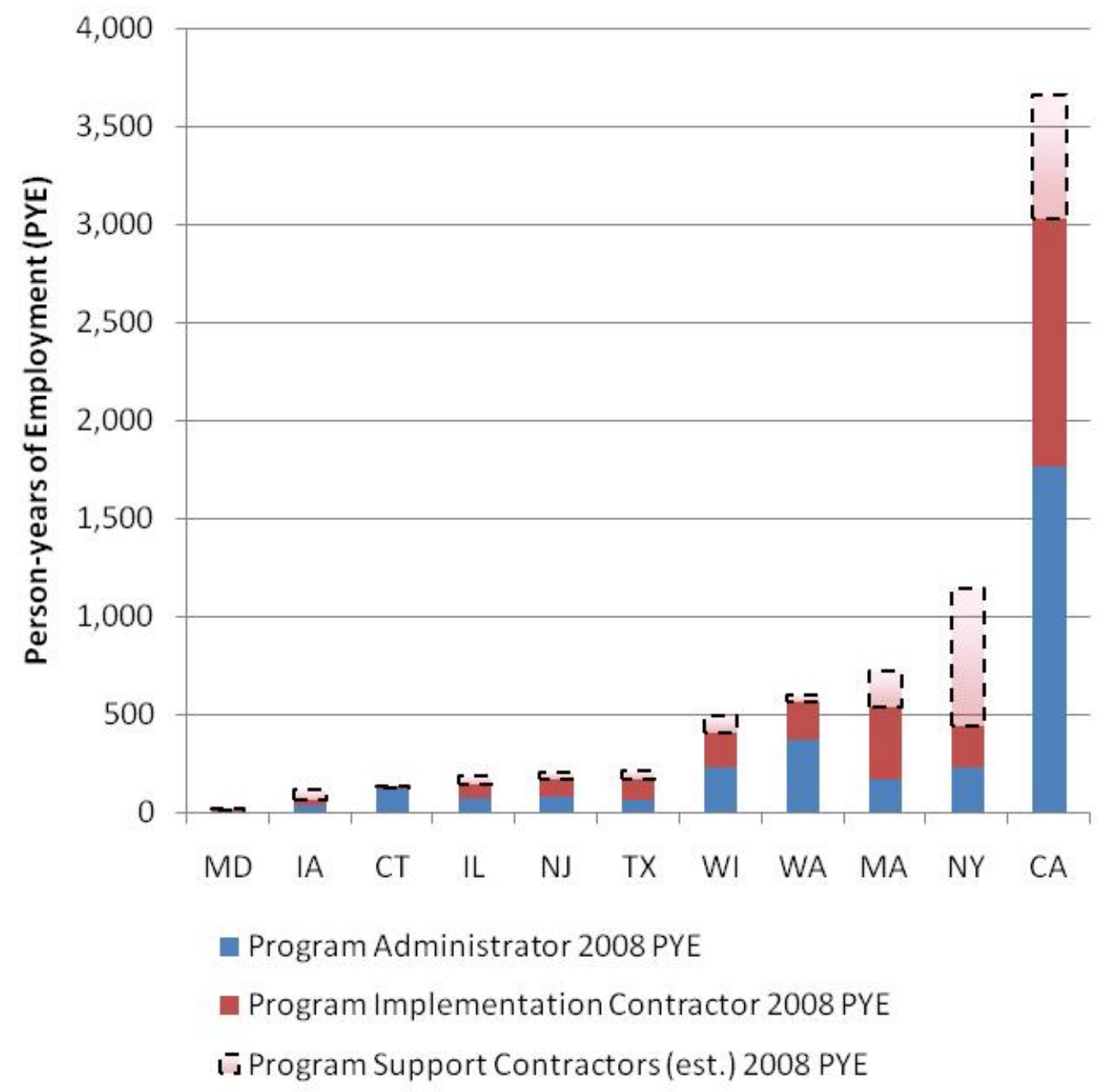

Figure 16: Person-Years of Employment for Ratepayer-Funded Programs (2008): Program Administration and Implementation and Support Contractors

As Figure 16 illustrates, practices vary somewhat among states in their organization of program administration and implementation contractor staff, representing varying degrees of outsourcing. For example, in Washington, program administrators include many municipal utilities, which typically conduct the majority of program activities using in-house staff. In contrast, in New York, NYSERDA was the major organization administering ratepayer-funded programs in 2008 and they rely heavily on program support contractors, working closely under NYSERDA staff direction, to extend the hours and capabilities of the in-house staff. In Massachusetts, utility administrators similarly have a lean administrator staff in relation to total administrator/contractor workforce, while Wisconsin and California operate with roughly equal proportions of administrator staff and contractor staff of both types.

We also included estimates of regulatory staff involved in overseeing ratepayer-funded energy efficiency programs in our workforce estimates. We conducted brief interviews with contacts at the utility commissions in the 11 states. The contacts estimated relatively few staff (typically, 
less than a dozen FTE) dedicated to energy efficiency; these are included in our estimates of program administrator staffing. We did not attempt to collect information on regulatory agency budgets for overseeing ratepayer-funded energy efficiency programs.

\subsubsection{Building and Construction Industry Workforce supported by Ratepayer-funded Energy Efficiency}

Ratepayer-funded energy efficiency activity employs many professionals and trades people in the building and construction industry to design and construct energy-efficient buildings, design and implement retrofit projects in buildings, and specify and install energy-efficient equipment. The program administrators typically buy down the cost of energy efficiency projects by providing rebates and incentives to building owners and energy consumers. The building owners and energy consumers also invest their own money, paying the difference between the total project cost and the incentive.

Based on our consultations with experts in the field, we assume that the average incentive covers one-third of the total project cost (not the incremental cost of efficiency). We estimated from our survey data of 39 program administrators the average proportion of total administrator budget used for incentives (53\%) and then estimated the total cost of energy efficiency projects driven by this amount of incentive spending. We then applied a labor factor (60\%) to the total project cost in order to estimate the proportion of total project cost comprised of labor, which allowed us to estimate the direct workforce market activity leveraged by ratepayer-funded energy efficiency programs market.

Figure 17 illustrates the program administrator spending on all activities - administration, support contractors, incentives to customers, and the induced market spending by customers currently and through 2020 under the high funding scenario. We estimate that induced spending on energy efficiency projects by customers matches administrator spending roughly one-for-one. 


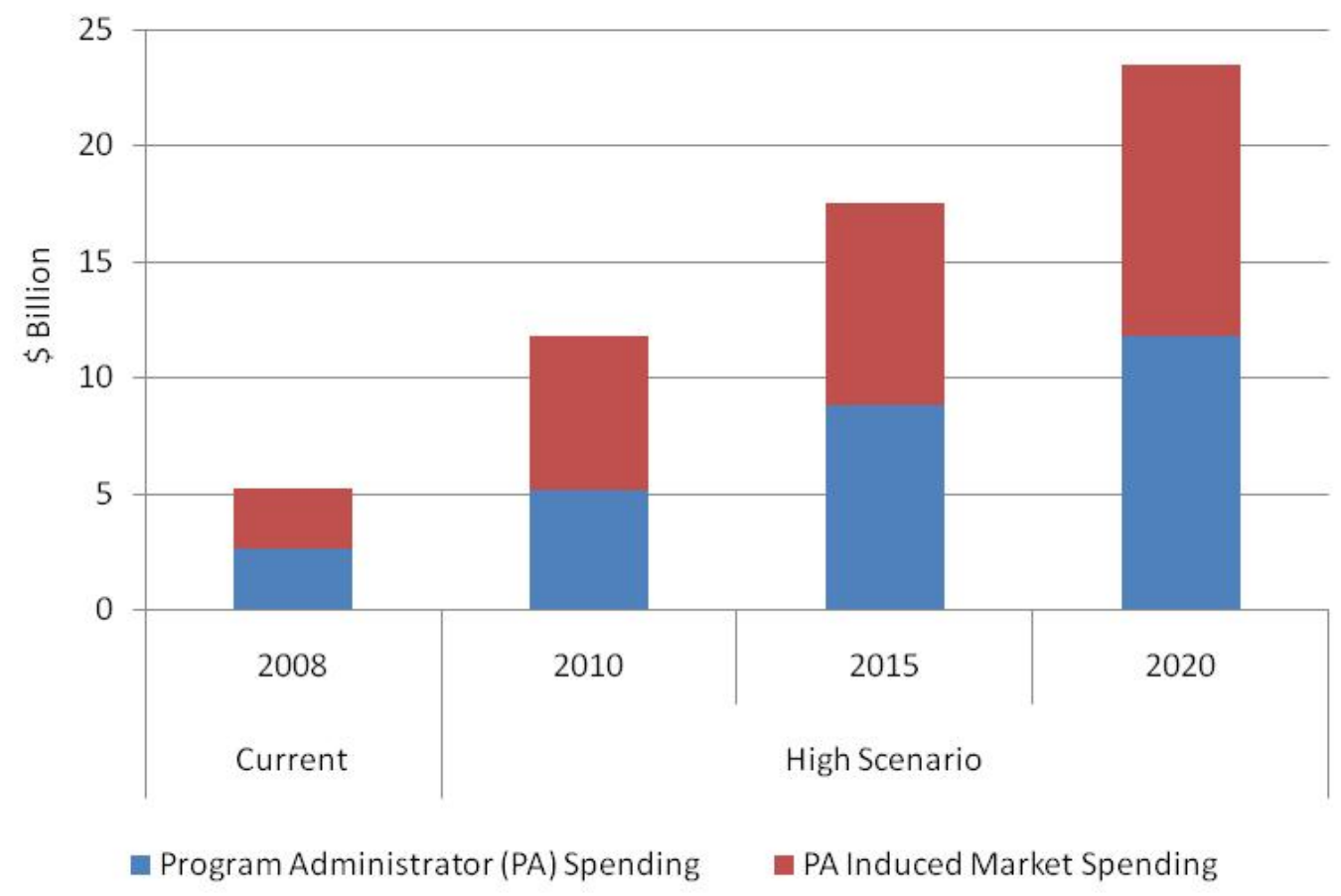

Figure 17: Program Administrator Funding and Leveraged Market Spending by Customers

\subsection{Energy Service Companies}

In order to develop estimates of the amount of energy efficiency activity undertaken by ESCOs, we drew initially upon a LBNL survey of 46 ESCOs that provided estimates of 2006 ESCO industry revenues (Goldman and Hopper 2007). For this study, we also interviewed nine large ESCOs which provided information on their 2008 revenues and staffing levels; these companies comprise more than $50 \%$ of the market. Based on these interviews, we estimated that ESCO staffs grew by 33\% from 2006 to late 2008, which is a little over 10\% per year for a three-year period. Energy efficiency performance contracting accounts for about 75\% of ESCO market activity or about $\$ 3.75$ billion in 2008; renewable energy accounts for the bulk of the remaining revenue (Goldman and Hopper 2007). ${ }^{38}$ Using data from Goldman and Hopper (2007), we estimate that ESCO energy efficiency activity in the 11 case study states comprises about $47 \%$ of total ESCO activity nationally.

We developed estimates of future ESCO revenues in energy efficiency performance contracting drawing upon several sources: 1) results of the 2006 ESCO survey (Hopper and Goldman 2007) that provided ESCO projections for the near term, 2) interviews with representatives from nine ESCOs completed in December 2008, and 3) discussions with several experts who consult on the ESCO industry.

\footnotetext{
${ }^{38}$ ESCOs report they conduct about $10 \%$ of their efficiency work for program administrators. Our analysis does not adjust the data for this small double-counting bias.
} 
In the near term, there are contradictory forces that increase uncertainty in projecting ESCO revenues. The deep economic recession has dampened ESCO market activity because of additional constraints for customers and ESCOs to obtain financing for projects, risk aversion by ESCOs trying to ensure adequate working capital, and tightening lending standards. On the other hand, ARRA provides a significant increase in spending on public sector energy efficiency for "shovel-ready" projects that could lead to large increases in near-term ESCO revenues, subject to constraints on available workforce capacity among state agencies that need to contract with ESCOs and workforce constraints faced by ESCOs.

Our low growth scenario represents business-as-usual. We forecast that ESCO energy efficiency revenues will increase between 8\% per year to 2020 based on the following market drivers:

- Continued expansion of the federal market with the recent award of new energy service performance contracts,

- Ongoing need for facility improvements and equipment replacement in public sector markets,

- Increasing momentum for performance contracting as a strategy that allows states to "lead by example” by retrofitting public sector buildings, and

- Near-term momentum and increased funding for state and local government markets created by ARRA.

In our high growth scenario, we project that ESCO revenues grow by about $12 \%$ per year to 2020, due to the combined impact of existing market drivers plus other factors. These other factors include:

- A long-term, aggressive commitment by the Federal government to energy efficiency that could involve national legislation that aggressively promotes energy efficiency (e.g., an Energy Efficiency Resource Standard),

- Ongoing funding and larger programs administered by state energy offices, and

- Greater market penetration of performance contracting in several market segments (e.g., private universities, Section 8 housing, owner-occupied commercial buildings, large-scale energy efficiency initiatives sponsored by local government).

Based on these assumptions, we forecast that ESCO revenues in 2020 from energy efficiency projects will range between $\$ 15.8$ billion and $\$ 24.5$ billion in the low and high growth scenarios respectively. ${ }^{39}$

\footnotetext{
${ }^{39}$ Projected revenues are in nominal dollars. See Appendix A.1 for the assumed inflation rate. In our revenue projections for 2015 and 2020, we assume that energy efficiency projects continue to account for about $75 \%$ of total ESCO revenues. ESCOs utilize incentives from ratepayer-funded programs in about $17 \%$ of their projects (Larsen et al. 2010). For ESCO projects installed from 2005-2008, incentives from ratepayer-funded energy efficiency programs accounted for about 1\% of ESCO project costs (Satchwell et al. 2010). We do not explicitly account for any potential double-counting in employment estimates between ratepayer-funded energy efficiency programs and ESCO industry activity, because we believe these effects to be small.
} 


\subsubsection{Building and Construction Trades Supported by ESCO Projects}

Data from Goldman and Hopper (2007) enabled us to estimate the number of building and construction professionals and trades people with whom ESCOs subcontract (see Appendix C.8 for methodology). We estimate that for every ESCO FTE employee, ESCOs subcontract with about 1.25 FTE of labor by building and construction contractors in their projects.

\subsection{Insulation Market: Building and Construction Trades conducting Code-Related Activity}

Insulation workers are a distinct occupation that is tracked by the BLS (Occupational Code 472130). BLS further segments these workers into those installing building envelope insulation ("insulation workers, floor, ceiling, and wall” - Occupational Code 472131) and mechanical insulation ("insulation workers, mechanical” - Occupational Code 472132).

According to insulation industry professionals interviewed for this study, building envelope insulation refers primarily to residential applications, with some small commercial, while mechanical insulation includes primarily insulation on pipes and equipment internal to the building, but also includes envelope insulation for large commercial structures. Building energy codes set minimum insulation requirements for various regions of the U.S., inducing the bulk of the spending on building envelope insulation. Commercial establishments tend to install mechanical insulation to optimize equipment performance as well as to reap energy savings. ${ }^{40}$

We obtained revenue and employment data for the insulation market from the U.S. Economic Census. Given the strong relationship between envelope insulation activity and building energy codes, we were disappointed when our analysis revealed little variation across states when revenues and workers were normalized by state population. This finding is suspect because the states vary widely in energy codes, climates, building stock characteristics, and rates of new construction - all drivers of the quantity of insulation installed.

Industry contacts we interviewed provided estimates of the national market size; however, interviewees may have been citing information gleaned from the Economic Census. The BLS 2006 data includes a forecast of industry employment in 2016. We used the implied annual growth rate (just under 1\%) for our low growth scenario. For our high scenario, we used the growth rate implied in our high spending case for ratepayer-funded energy efficiency (12\%) to project future revenues in the insulation market.

\subsection{Direct Workforce Employment and EESS Activity: Summary}

Table 10 summarizes our findings of PYE/\$1M dollars of spending on EESS activity. Note that the PYE values in this study capture only direct employment in the activities of designing and installing efficiency measures and do not capture jobs that indirectly result from EESS activity.

\footnotetext{
40 Regardless of the benefit explicitly recognized, the performance and energy benefits of mechanical insulation are hard to separate. Typically, excess heat energy is a culprit in low equipment performance. While energy codes have less influence on total spending on mechanical insulation than on building envelope insulation, efficiency codes and standards nonetheless play a role in inducing installation of mechanical insulation
} 
Table 10: Person-Years of Employment in the Energy Efficiency Services Sector: 2008

\begin{tabular}{|c|c|c|c|}
\hline Activity & $\begin{array}{c}\mathbf{2 0 0 8} \\
\text { Spending } \\
\text { (in \$M) }\end{array}$ & $\begin{array}{c}\text { 2008 Person-Years of } \\
\text { Employment }\end{array}$ & $\begin{array}{c}\text { Person-Years of } \\
\text { Employment per } \\
\text { \$1M in spending }\end{array}$ \\
\hline $\begin{array}{c}\text { Weatherization assistance (excluding program } \\
\text { administrator assistance) }\end{array}$ & $\$ 528$ & 4,700 & 8.9 \\
\hline $\begin{array}{c}\text { Government (federal and state) } \\
\begin{array}{c}\text { Program administrators, program implementation } \\
\text { contractors, program support contractors, and } \\
\text { associated building and construction industry }\end{array}\end{array}$ & $\$ 243$ & 1,600 & 6.5 \\
\hline $\begin{array}{c}\text { ESCOs and associated building and construction } \\
\text { industry }\end{array}$ & $\$ 4,957$ & 32,600 & 6.2 \\
\hline $\begin{array}{c}\text { Building and construction industry influenced by } \\
\text { codes and standards (insulation) }\end{array}$ & $\$ 7.091$ & 12,200 & 2.5 \\
\hline Total & $\mathbf{\$ 1 8 , 0 4 3}$ & $\mathbf{1 1 4 , 0 0 0}$ & 8.9 \\
\hline
\end{tabular}

On average, we find that for each $\$ 1$ million invested in EESS activity, 6.3 jobs are created, ranging from 2.5 jobs in ESCO activity to 8.9 jobs in weatherization and insulation activity. Our average estimate of PYE (6.3) falls between the 3.8 estimated by the American Solar Energy Society (Bedzek 2007) -and the 9.8 estimated by the American Council for an Energy Efficient Economy (ACEEE 2009) (see Table 11).

Table 11: Other Clean Jobs Studies Estimates of Person-Years of Employment per Million Dollars in EESS Activity

\begin{tabular}{|c|c|c|c|}
\hline Study & Job Type & $\begin{array}{c}\text { Total Investment } \\
\text { (in \$M) }\end{array}$ & $\begin{array}{c}\text { Person-Years of } \\
\text { Employment per \$M }\end{array}$ \\
\hline UMASS-PERI and CAP (2008) & $\begin{array}{c}\text { Green Jobs } \\
\text { (direct) }\end{array}$ & $\begin{array}{c}\$ 100,000 \\
\text { (hypothetical scenario) }\end{array}$ & 9.4 \\
\hline Apollo Alliance (2004) & $\begin{array}{c}\text { \$90,000 } \\
\text { (hypothetical scenario) }\end{array}$ & 9.2 \\
\hline ACEEE (2008) & $\begin{array}{c}\text { Energy Efficiency } \\
\text { (efficiency premium) }\end{array}$ & $\$ 24,000$ & 3.8 \\
\hline $\begin{array}{c}\text { Energy Efficiency } \\
\text { (direct) }\end{array}$ & $\$ 932,600$ & 4.7 \\
\hline
\end{tabular}




\section{Regional Surveys of Energy Efficiency Employers}

In this chapter, we provide a comparative review and analysis of four recent studies that surveyed employers offering various types of energy efficiency services in California, Massachusetts, the Pacific Northwest, and Connecticut. In some cases (California and Massachusetts ${ }^{41}$ ), LBNL developed a partnership with the organization conducting the employer surveys which meant that we provided some input on the design of the survey instrument (e.g., questions asked) and had access to the raw data to analyze results.

These surveys of individual employers reveal the types of energy efficiency services offered, employers' expectations about revenue and job growth, barriers to hiring qualified employees, and training needs. The samples surveyed do not represent the entire population of a state or region. The survey results complement our interviews with representatives of building and construction trade and professional associations by providing more detailed information about the types of firms in a state or region, firm size distribution, and the market sectors served by these firms.

It is also worth noting where the respondents of these studies differ from the market segments we target in our study. In some cases the types of employers interviewed included entities such as equipment manufacturers or distributors, and/or large customer facility or energy managers that were not included in the LBNL study (see Figure 18). Three of the four case studies did not survey program administrators (e.g., utilities), although program implementation contractors that provide energy efficiency services to utilities were included.

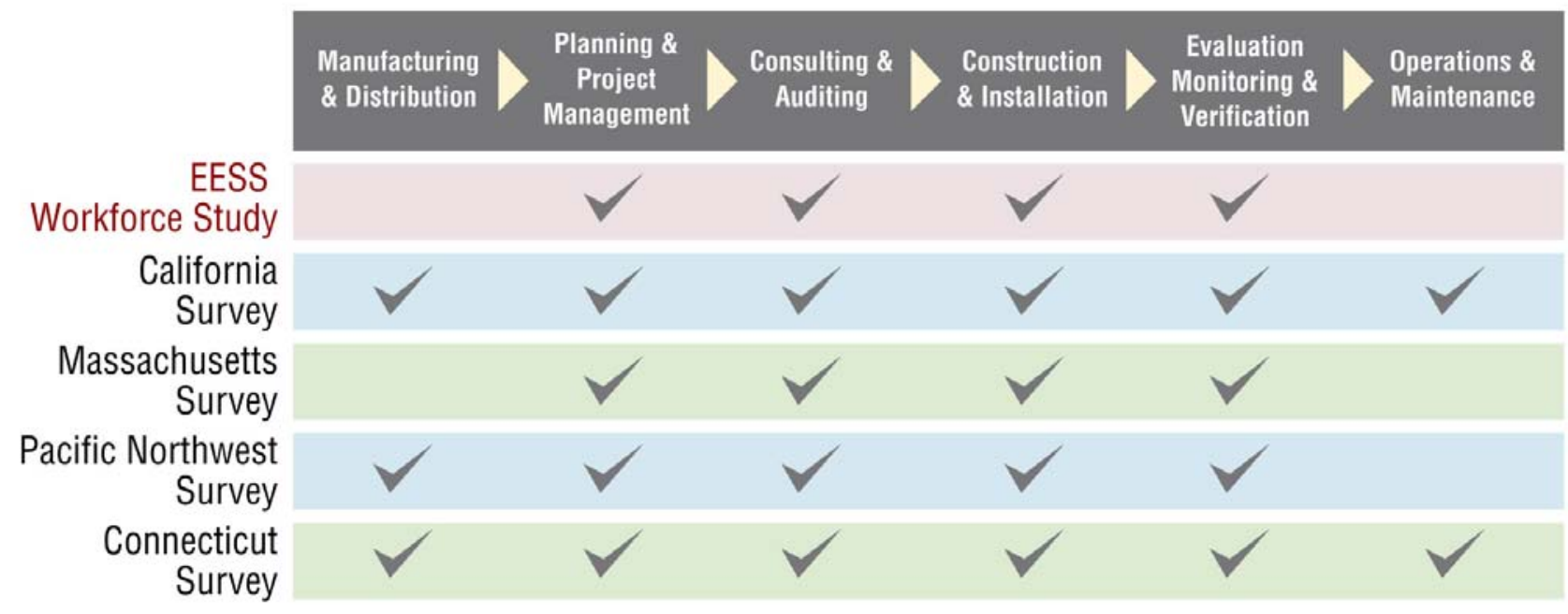

Figure 18: Segments of Energy Efficiency Value Chain Included in Employer Surveys

\footnotetext{
${ }^{41}$ LBNL was a technical advisor to the San Francisco Bay and Greater Silicon Valley Centers of Excellence (COE) which designed the California survey, and to the New England Clean Energy Council which conducted the Massachusetts survey.
} 


\subsection{California Employer Survey}

The Centers of Excellence (COE) across California, which serve the California community colleges, used a survey designed by the San Francisco Bay and Greater Silicon Valley COEs to conduct an employer survey in California between December 2008 and July 2009. Drawing from a wide array of lists of employers provided by partner organizations, they received responses from over 1,100 businesses in the state.

\subsubsection{Employer Characterization}

The services offered by California businesses are similar to those offered by businesses in other regions, with consulting, construction, HVAC, project management, engineering, and lighting topping the list. When given a narrower list of "industries" to identify with, the responses revealed a more descriptive picture of existing employers. As seen in Figure 19, almost 50\% of the firms are involved in the design and construction of new buildings and homes, whereas $34 \%$ work on improving existing buildings, and 39\% work on improving existing homes. In addition, building operations and maintenance are performed by $17 \%$ of firms, and $8 \%$ offer services for utilities or are energy resource managers. Many of the firms work in multiple sectors: $76 \%$ of firms reported that they serve commercial sector customers, followed by $70 \%$ serving the residential sector, $50 \%$ serving the public or institutional sector, and $47 \%$ serving the industrial sector. Activity in the residential sector in California is significantly higher than seen in the Pacific Northwest or Massachusetts employer surveys, which are discussed later in this chapter.

These firms employ almost 45,000 people, with an average of 31 employees per business; only about a quarter of these employees perform energy efficiency-specific work (see Figure 21). ${ }^{42}$ The highest percentage of businesses have 10 or fewer employees, with 55\% of firms in this category (see Figure 20). Over 95\% of firms have 100 or fewer employees.

\section{Table 12: Types of Energy Efficiency Services Offered by California Employers}

\begin{tabular}{|l|r|}
\hline \multicolumn{2}{|c|}{ Services Offered } \\
\hline Consulting & $51 \%$ \\
\hline Construction & $33 \%$ \\
\hline HVAC-R & $29 \%$ \\
\hline Project management & $28 \%$ \\
\hline Engineering & $26 \%$ \\
\hline Electrical & $23 \%$ \\
\hline Lighting & $22 \%$ \\
\hline Controls & $17 \%$ \\
\hline Architecture & $16 \%$ \\
\hline Commissioning & $15 \%$ \\
\hline Marketing and sales & $14 \%$ \\
\hline
\end{tabular}

\footnotetext{
42 The CA COE survey did not ask whether employment was in-state or whether employees from other states were included in respondent's estimates.
} 


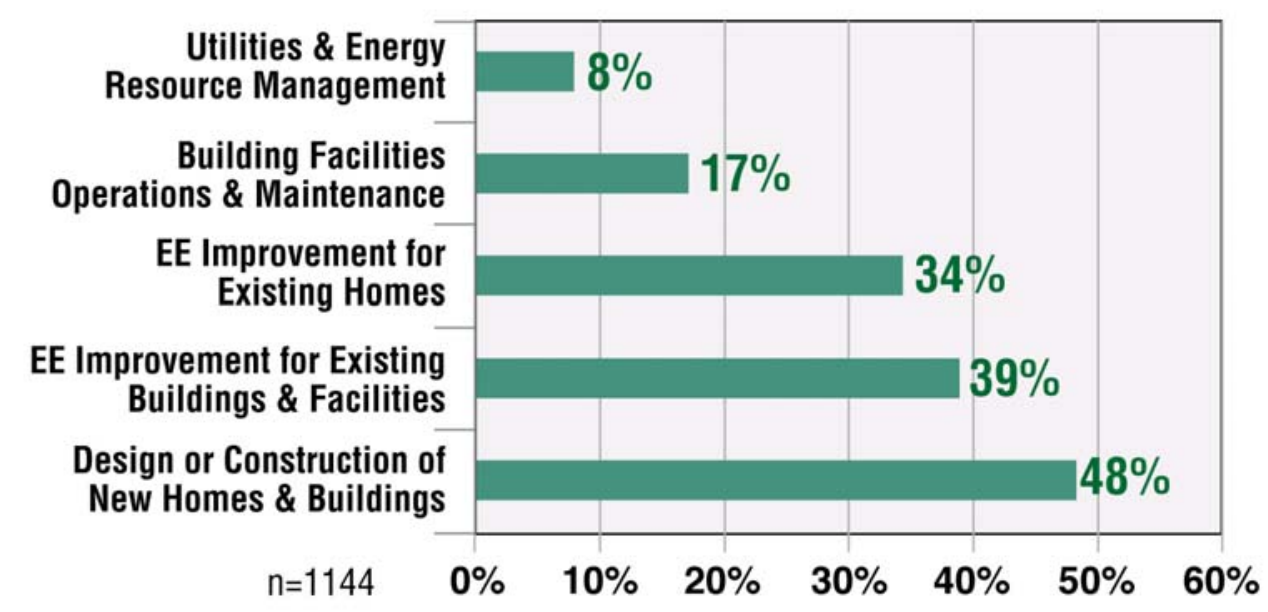

Figure 19: Industries Identified by California Businesses, Multiple Responses Allowed

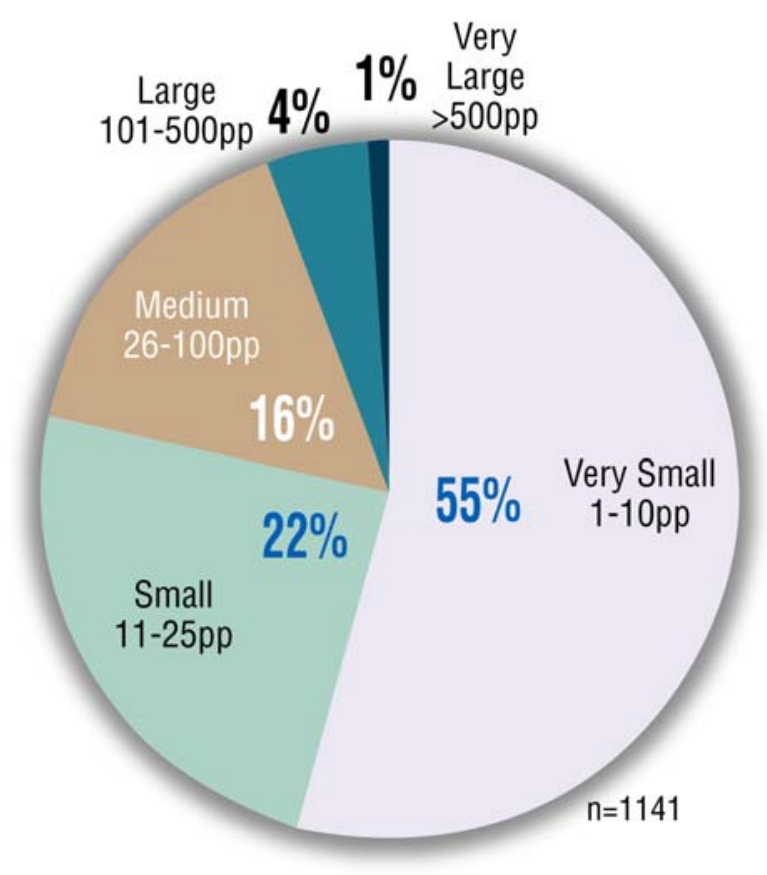

Figure 20: Distribution of Firm Size among Energy Efficiency Service Providers in California

The COE survey also asked about eight specific energy efficiency occupations (see Figure 21). One important observation is that only $28 \%$ of the 44,700 employees work in these occupational categories. There may be other energy efficiency-focused jobs not included in these eight categories, but it is clear that many jobs at firms in the energy efficiency services sector do not require energy efficiency-specific skills. Among the eight energy efficiency occupations, the 
largest category by far is project managers for construction or design work; $69 \%$ of the firms surveyed have at least one position that fits this description. Project managers for construction and design work account for $9 \%$ of all jobs and 31\% of the energy efficiency-specific jobs at thefirms surveyed.

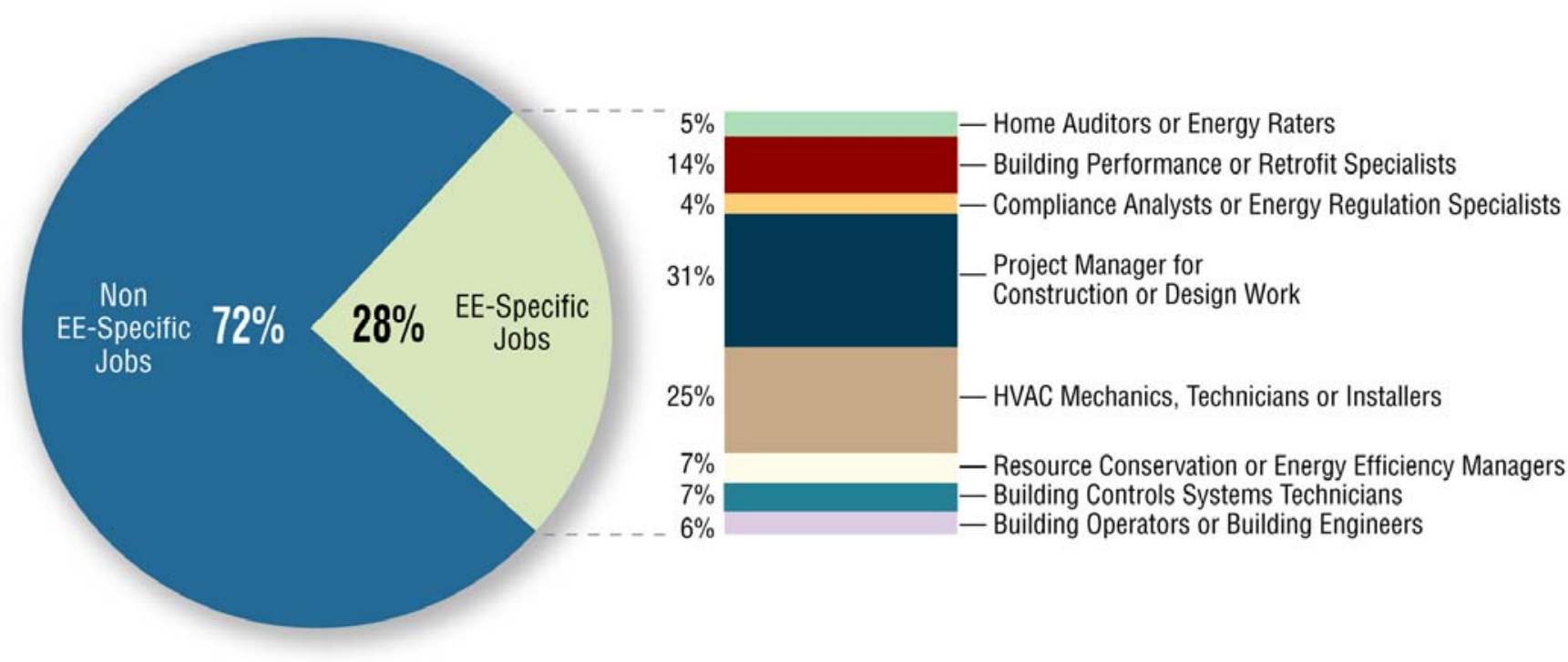

Figure 21: Employer Data for Eight Specific Energy Efficiency Occupations

\subsubsection{Expectations for Growth}

The COE asked survey respondents to forecast job growth in the eight efficiency occupations over the next 12 months and three years; results are shown in Figure 22, along with the percentage of jobs in each category to add perspective. For example, firms projected a $158 \%$ increase in the number of building operators and engineers and a $112 \%$ increase in the number of energy auditors over the next three years; however, these are some of the smaller job categories (i.e., $6 \%$ and $5 \%$ respectively) among the eight efficiency occupations. In contrast, employers projected a growth of $59 \%$ for project managers over the next three years; this is the largest job category so the total number of jobs added is greater. In general, the 12-month job growth projections were between $13 \%$ and $39 \%$ and the three-year projections were between $59 \%$ and $158 \%$ for the eight energy efficiency occupations. The survey also revealed much higher growth expectations for these job categories compared to the other jobs at these firms. The average 12month expectation for growth in all job categories was $2 \%$ versus $20 \%$ on average for these eight energy efficiency categories. ${ }^{43}$

\footnotetext{
${ }^{43}$ The growth rates in our report are significantly higher than those reported in COE's statewide report, for two reasons: 1) we used a sub-set of the data by excluding end customers of energy efficiency services (e.g., energy managers in organizations whose principal business is not energy efficiency), and 2) we used imputed values for missing data for survey questions that asked respondents for the number of people currently employed and their estimates of employees in the future (i.e.,12 months and 3 years from the survey) The imputed values are the mean values of number of employees by category (EE services, manufacturing and utilities). We calculated the mean by only selecting respondents that indicated they had 4 or less of the eight occupations.
} 


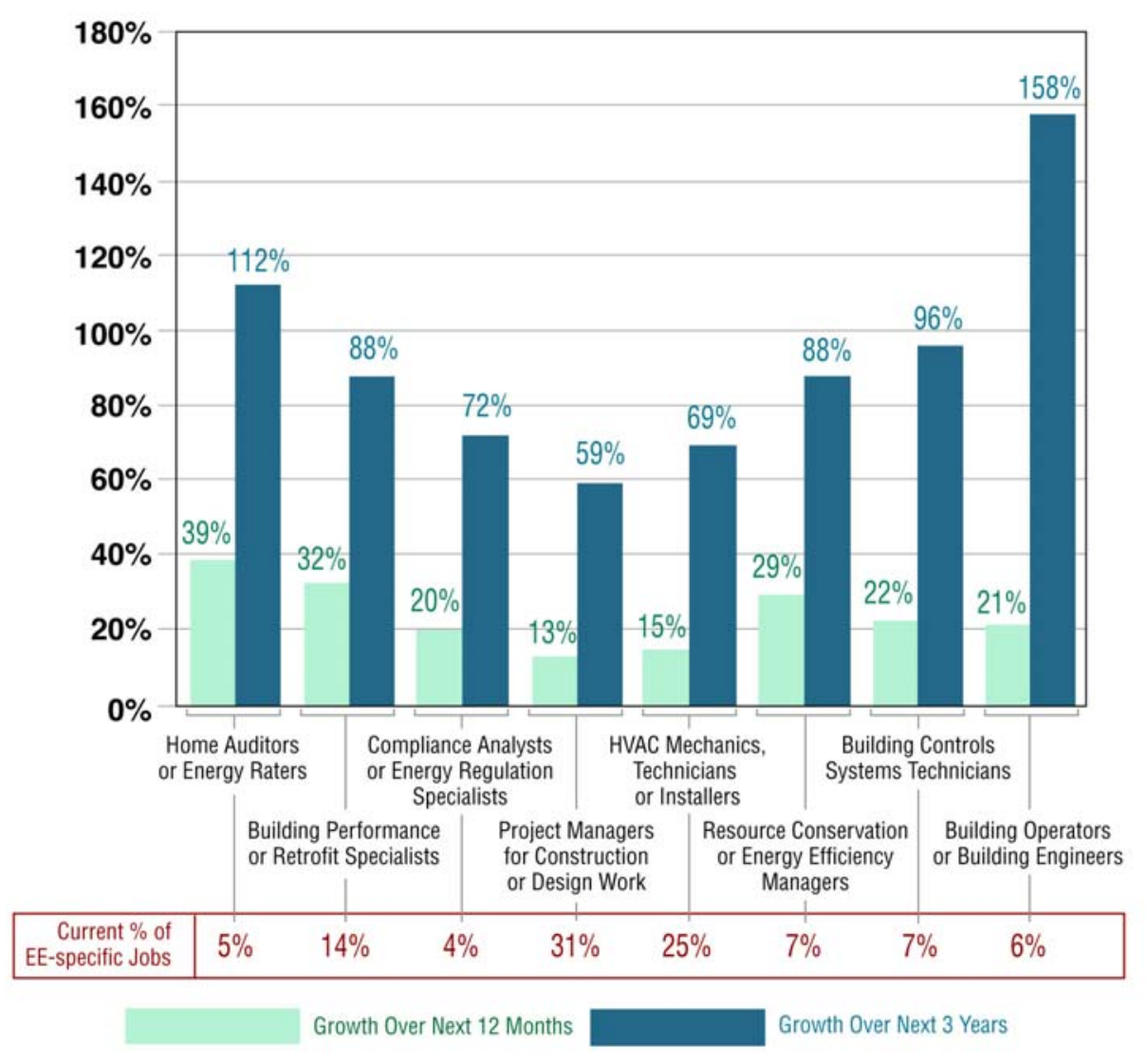

Figure 22: Job Growth Expectations in 12 Months and 3 Years for California Employers

\subsubsection{Workforce Development Needs}

The businesses surveyed expressed a surprisingly high level of difficulty in hiring people for the eight energy efficiency occupations (see Figure 23). The percent of employers that were experiencing "some” or "great" difficulty in hiring range from 56\% to 73\%, depending on the occupational category. The most difficult categories are building operators/engineers and energy efficiency managers, but all categories seem to have significant difficulty in hiring qualified employees. Employers across all job categories also identified three important skill areas for potential employees: 1) the ability to communicate in writing and in person, 2) understanding of state and local energy efficiency requirements and incentives, and 3) general understanding of the mechanics of energy systems, including HVAC, lighting, and renewable energy. The COE survey also asked questions about the community college offerings. Employers responded positively; 73\% were interested in an internship program, 64\% were interested in a one-year certificate in energy auditing and retrofitting, $62 \%$ were interested in onsite training for their 
current employees, and 60\% were interested in an associate's degree in resource and conservation management.

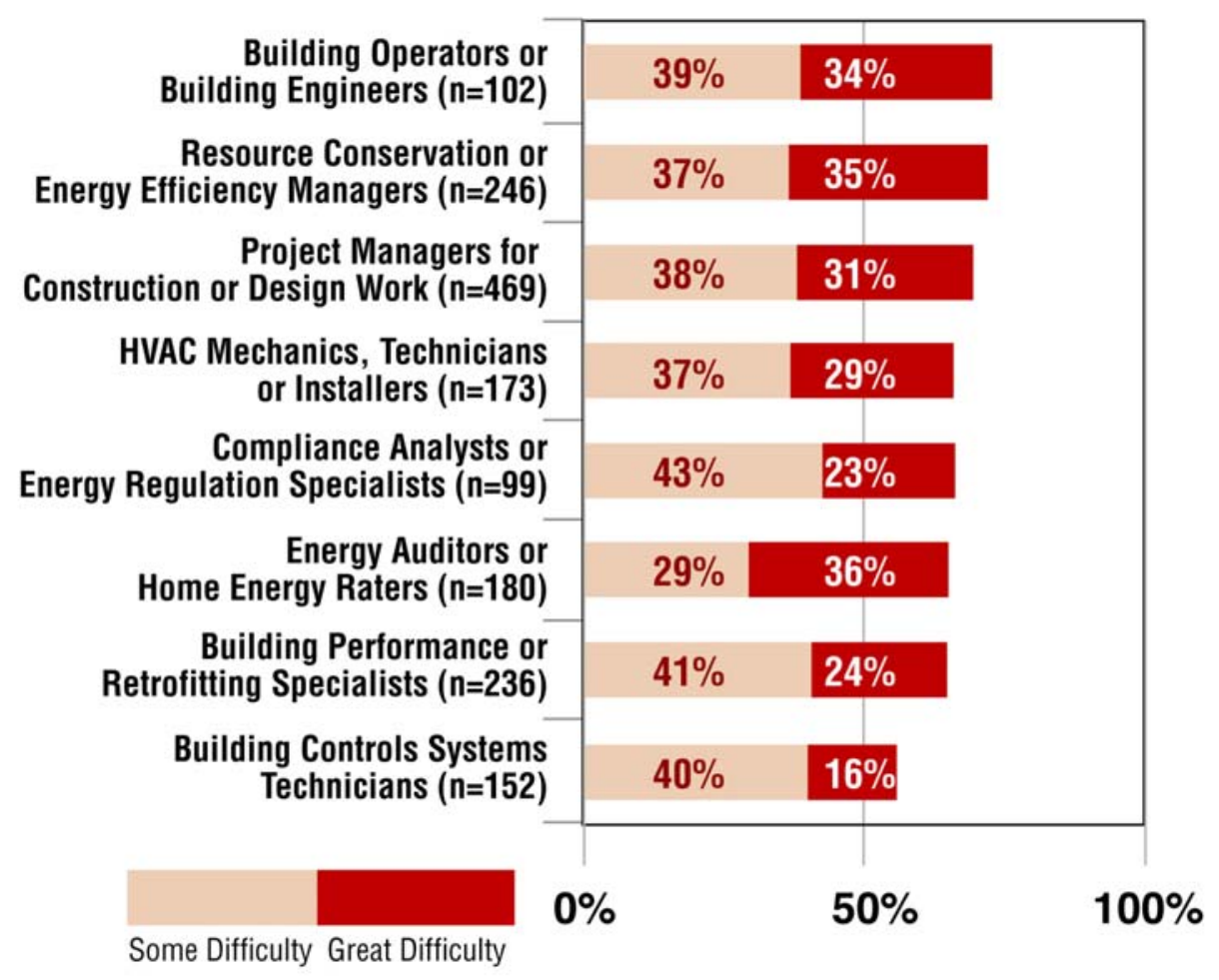

Figure 23: Difficulty in Hiring for the Eight Energy Efficiency Occupations

\subsection{Massachusetts Employer Survey}

In January 2009, the UMass Donahue Institute, the New England Clean Energy Council (NECEC), and the Massachusetts Renewable Energy Trust collaborated to conduct the Massachusetts Clean Energy Industry Census. Of the almost 400 responses from a range of firms in the clean energy sector, our team deemed that at least 76 provide energy efficiency services; results for this energy efficiency cohort are summarized in our case study. ${ }^{44}$

\subsubsection{Employer Characterization}

The vast majority of the firms surveyed offer services related to building efficiency; $67 \%$ offer residential or commercial building system services, followed by lighting (43\%), weatherization

\footnotetext{
${ }^{44}$ Due to the overlapping categories included in the survey, it was difficult to isolate the energy efficiency employers from other clean energy firms; thus our sample of the number of employers that provide energy efficiency services is a lower bound.
} 
(16\%), information systems (16\%), and consulting (16\%) (see Table 13). These firms employ over 9,500 people in Massachusetts, with an average firm size of 128.

Table 13: Types of Energy Efficiency Services Offered by Massachusetts Employers

\begin{tabular}{|l|c|}
\hline \multicolumn{2}{|c|}{ Services Offered } \\
\hline $\begin{array}{l}\text { Residential/Commercial } \\
\text { Building Systems }\end{array}$ & $\mathbf{6 7 \%}$ \\
\hline Lighting & $\mathbf{4 3 \%}$ \\
\hline Weatherization/Insulation & $\mathbf{1 6 \%}$ \\
\hline Information Systems & $\mathbf{1 6 \%}$ \\
\hline General consulting & $\mathbf{1 6 \%}$ \\
\hline Metering & $\mathbf{1 1 \%}$ \\
\hline $\begin{array}{l}\text { Energy Storage and/or Power } \\
\text { Electronics }\end{array}$ & $\mathbf{8 \%}$ \\
\hline Social Marketing & $\mathbf{5 \%}$ \\
\hline Other & $\mathbf{1 1 \%}$ \\
\hline
\end{tabular}

This employment number includes all jobs within each firm, not just those with efficiencyspecific roles. These businesses tend to be small - over half have 10 people or fewer, and $81 \%$ have 100 people or fewer (see Figure 24).

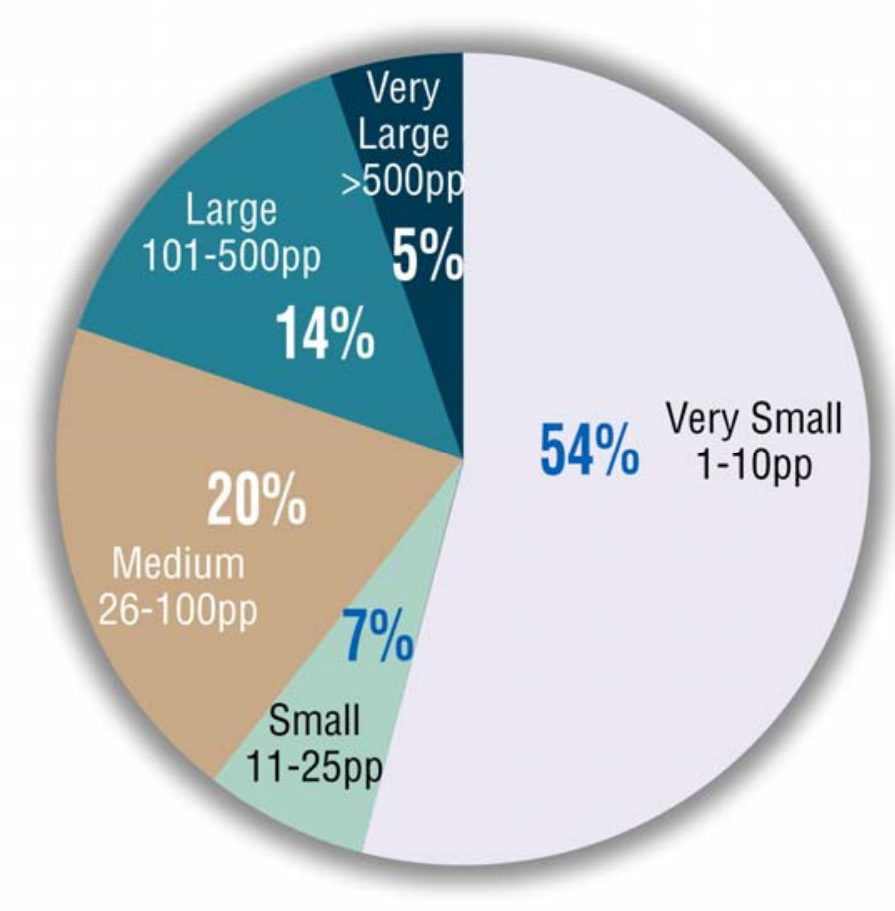

Figure 24: Distribution of Firm Size among Energy Efficiency Service Providers in Massachusetts 
Unlike the California and Northwest employer surveys, the Massachusetts survey asked how many of the firm's employees are based within the state. The respondents revealed that only $21 \%$ of the employees (2,040 total or 27 per firm on average) work in Massachusetts, suggesting that a majority of the firms have multi-state operations. ${ }^{45}$

\subsubsection{Expectations for Growth}

These businesses reported high rates of revenue growth in 2008, with slightly higher growth projections for 2009 . Figure 25 shows that $68 \%$ percent of firms experienced greater than $10 \%$ revenue growth in 2008, and $73 \%$ of firms expected this level of growth in 2009. It is important to note the survey particularly asked about growth in the "clean energy sector." These high growth rates can be explained to some degree by the fact that there are a large percentage of small firms; small nominal increases in revenue can easily translate into a 50 or $100 \%$ increase in revenues as small firms begin to grow.

In terms of growth in employee numbers, firms added 10 people on average in 2008 and planned to add 12 people (a 9\% increase on average in total employees) in 2009.

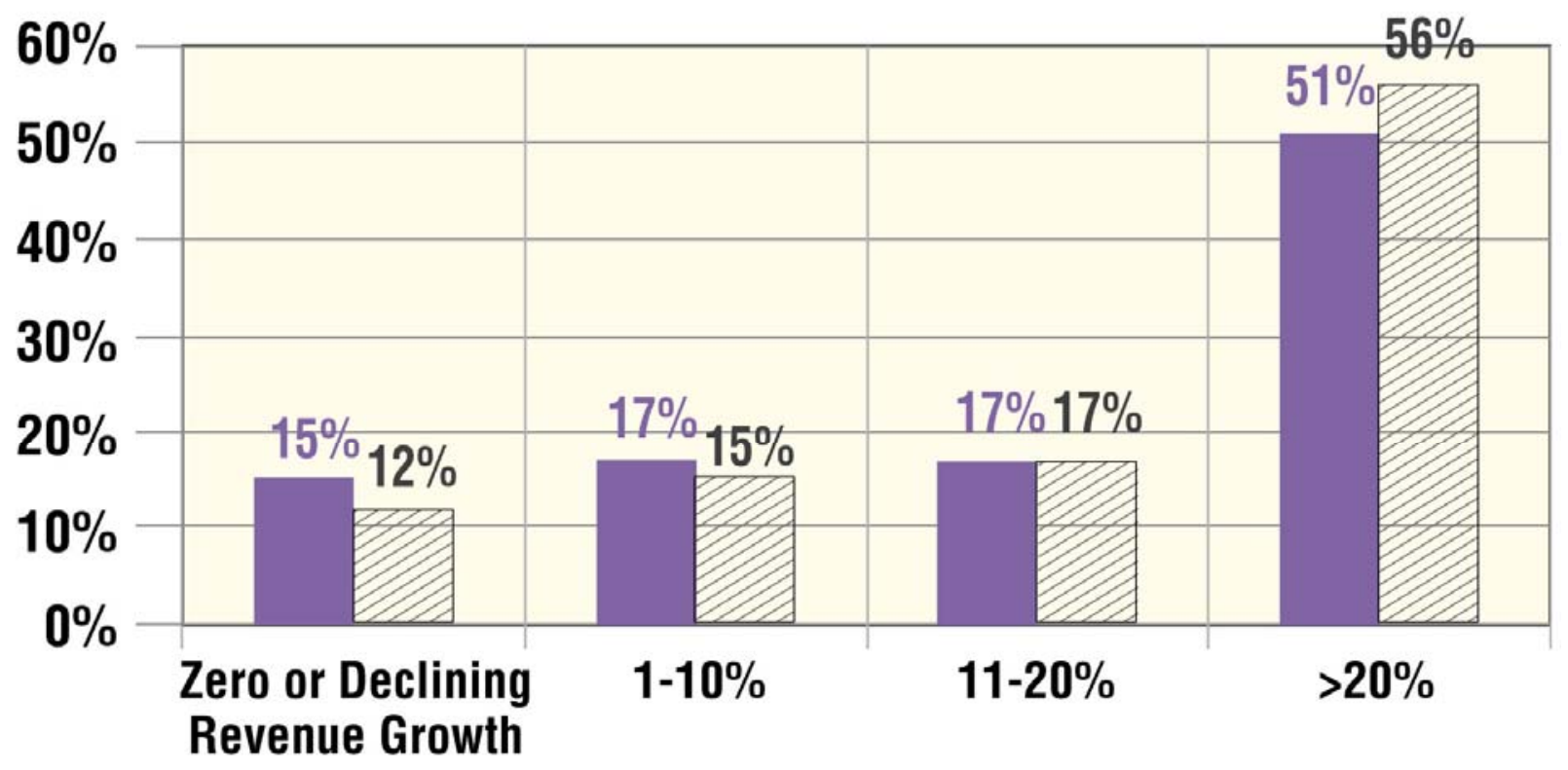

Clean Energy Revenue Clean Energy Projected

Growth Rate in 2008 Growth Rate in 2009

Figure 25: Actual and Projected Growth in "Clean Energy" Revenues for Massachusetts Energy Efficiency Service Providers (n=59)

\footnotetext{
${ }^{45}$ This implies that the California and Northwest employee numbers may overestimate the energy efficiency jobs located in their region if employers responded with their total number of employees, instead of just the employees based in the region.
} 


\subsubsection{Workforce Development Needs}

There is relatively little information about workforce development needs from this survey, as it was not designed for that purpose. Employees of these firms tend to have high educational attainment levels; $44 \%$ have a master's or doctoral degree, $49 \%$ have a four-year college degree, $4 \%$ have an associate's degree, and 3\% have high school or less as their highest level of education. When asked if they had any open positions in 2008 that they were not able to fill in 2008, 24\% said yes and 76\% said no. The two main reasons that firms were unable to fill positions were that applicants lacked: 1) relevant clean energy employment experience, and 2) necessary formal education or training.

We also reviewed an additional report based on a subsequent in-depth survey of the commercial and industrial (C/I) energy efficiency sector employers in Massachusetts; the study also was commissioned by NECEC (NECEC 2009). In this survey, C/I energy efficiency employers said that the market downturn would make it easy to fill certain types of positions, such as equipment installers and other roles that require less prior training. Similar to responses from other regions, there was an emphasis on hands-on field experience, and many employers believed that potential hires from many backgrounds could obtain the training they needed on the job. In contrast, engineers proficient in energy efficiency strategies were uniformly identified as the most difficult to find, which is consistent with our findings reported in Chapter 6. The report also identified qualified senior project developers, project managers, and qualified auditors as hard to find. To address this need, Massachusetts will soon launch a focused effort to train workers for jobs in the energy efficiency sector. The state’s Clean Energy Center has created the Massachusetts Energy Efficiency and Building Science Training Initiative, which will spend almost \$1.9 million on a variety of training programs through 2011.

\subsection{Oregon and Washington Employer Survey}

The Northwest Energy Efficiency Council (NEEC), a trade association representing companies in the energy efficiency industry, conducted a survey of regional energy efficiency businesses in summer 2008 to better understand the composition and needs of this sector. Over a two-month period NEEC received responses from about 100 of its association members in Oregon and Washington, a 29\% response rate.

\subsubsection{Employer Characterization}

The businesses surveyed offer a wide range of services, (see Table 14), with most offering more than one service.

Table 14: Types of Energy Efficiency Services Offered by Pacific Northwest Employers that Responded to the NEEC Survey

\begin{tabular}{|l|r|}
\hline \multicolumn{2}{|c|}{ Services Offered } \\
\hline Consulting & $\mathbf{4 8 \%}$ \\
\hline Engineering & $\mathbf{4 2 \%}$ \\
\hline Lighting & $\mathbf{3 2 \%}$ \\
\hline HVAC-R & $\mathbf{2 9 \%}$ \\
\hline
\end{tabular}




\begin{tabular}{|l|c|} 
Commissioning & $\mathbf{2 7 \%}$ \\
\hline Controls & $\mathbf{2 5 \%}$ \\
\hline Marketing and Sales & $\mathbf{2 4 \%}$ \\
\hline Project Management & $\mathbf{2 3 \%}$ \\
\hline Electrical & $\mathbf{2 0 \%}$ \\
\hline Non-technical Consulting & $\mathbf{1 8 \%}$ \\
\hline Industry Promotion & $\mathbf{1 3 \%}$ \\
\hline Product Representative & $\mathbf{1 3 \%}$ \\
\hline Utility & $\mathbf{1 3 \%}$ \\
\hline Construction & $\mathbf{1 2 \%}$ \\
\hline Product Manufacturing & $\mathbf{1 2 \%}$ \\
\hline Architecture & $\mathbf{7 \%}$ \\
\hline Retail sales & $\mathbf{3 \%}$ \\
\hline
\end{tabular}

The most common service offered is consulting, followed by engineering, lighting, HVAC, and commissioning. The vast majority of these businesses serve the commercial (86\%) and/or industrial (60\%) markets. Some of these firms also serve the residential market, but only $6 \%$ of firms serve the residential market exclusively.

Collectively these firms employ over 7,600 people, with an average of 80 employees per firm. This employment number includes all jobs within each firm, not just those with efficiencyspecific roles. Most of these firms are rather small, with 75\% employing under 100 people and 34\% employing 10 people or fewer (see Figure 27). The firm size varies somewhat by service (see Figure 26). Firms offering consulting services tend to be on the smaller end of the spectrum. The other services show a range of distribution in firm size. It is important to note that most firms offer multiple services, so there is significant overlap in these service categories.

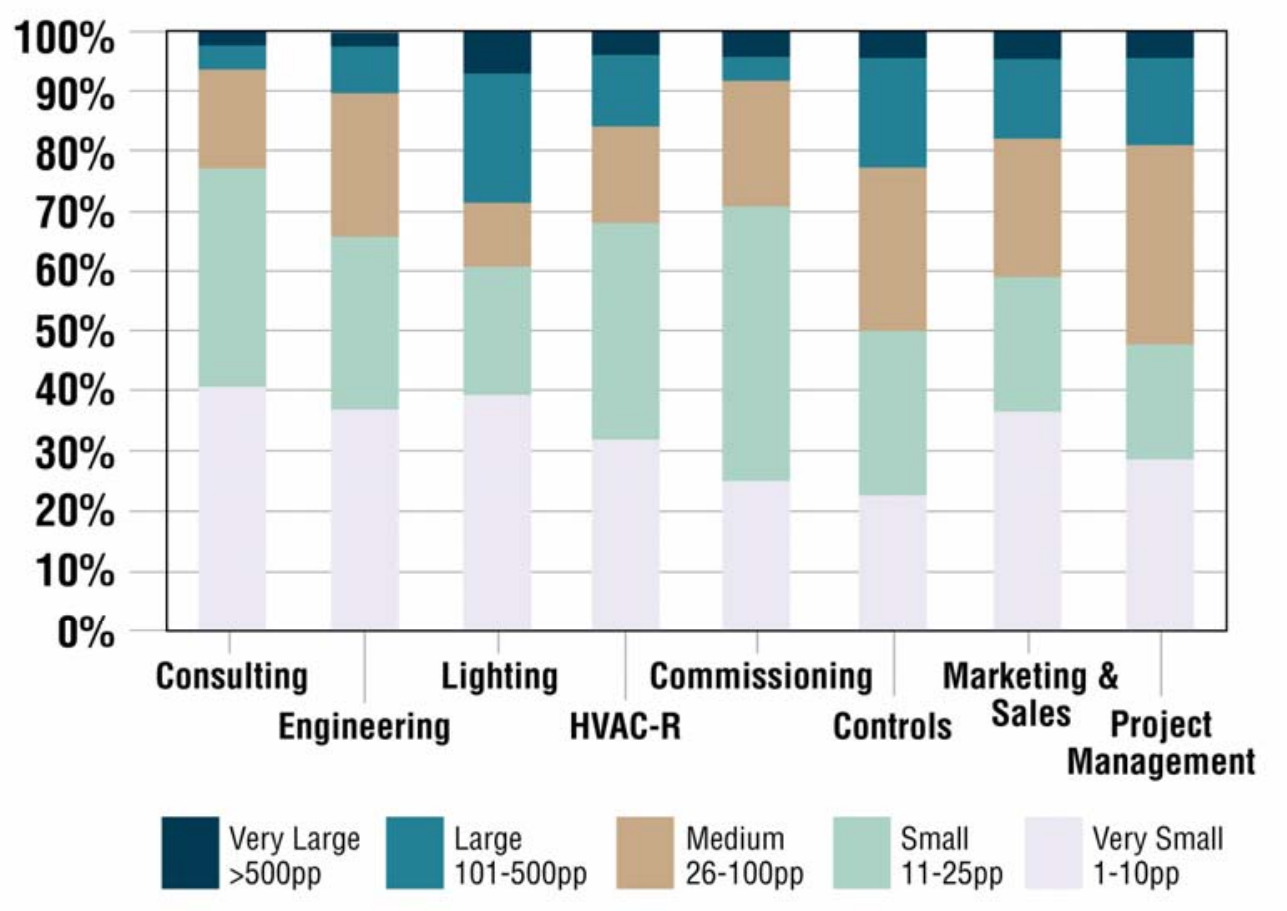


Figure 26: Firm Size in Pacific Northwest for the Top 8 Services Provided

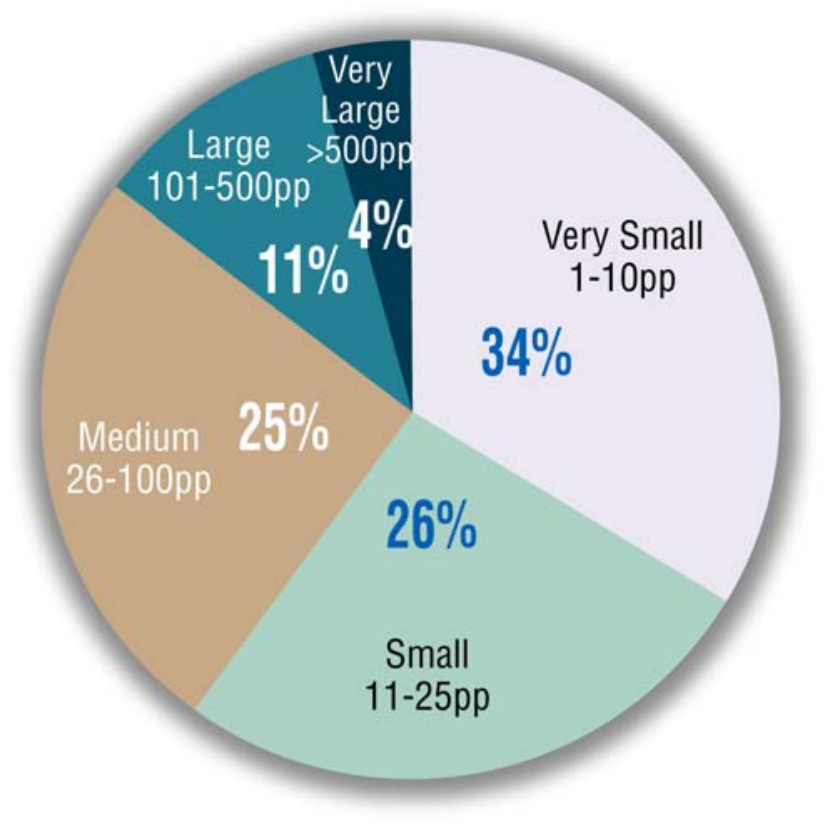

Figure 27: Distribution of Firm Size Among Energy Efficiency Service Providers in the Pacific Northwest

\subsubsection{Expectations for Growth}

These businesses reported high rates of revenue growth in 2007, and expected growth to continue over the next five years. More than half of the firms reported a revenue growth rate of over $5 \%$ in 2007 , with over $40 \%$ of the survey respondents reporting revenue increases of $8 \%$ or more (see Figure 28). Half of the firms also expected annual revenue increases of over $5 \%$ through 2013, with over $35 \%$ expecting annual increases of $8 \%$ or more. It is important to note that these projections were made before the economic downturn in October 2008. 


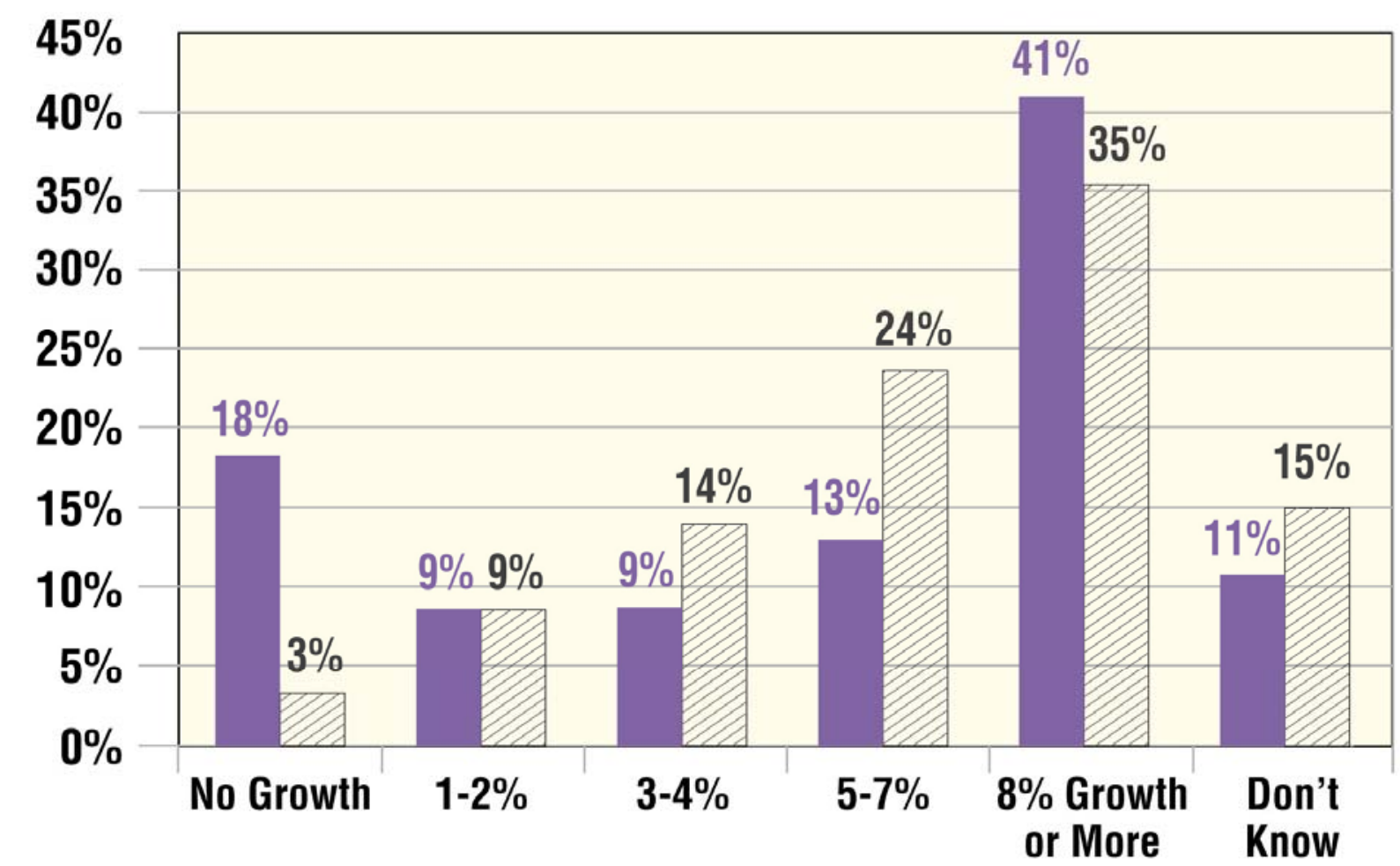

Revenue Growth Rate in 2007

Projected Annual Revenue Growth Over Next 5 Years

Figure 28: 2007 and Projected Average Annual Revenue Growth over Next Five Years for Pacific Northwest Energy Efficiency Service Providers

In 2007, almost 25\% of these firms hired more than 10 new employees, and most firms planned to hire many more over the next five years to keep up with their expectations for revenue increases. Respondents indicated the greatest areas of new job growth, listed in order of growth expectations: administrative support, engineering, marketing and sales, project management, and mechanical expertise.

\subsubsection{Workforce Development Needs}

The businesses surveyed expressed several common workforce development needs. About 30\% of survey respondents indicated that they were able to find skilled applicants in the region, while $64 \%$ said that they sometimes could find skilled applicants, and 6\% indicated that they could not find skilled applicants. Three key deficiencies in the current pool of job candidates stood out: $82 \%$ of respondents cited energy efficiency experience as a deficiency, followed by hands-on experience (56\%) and specific technical training (49\%). When asked about emerging needs of employers in this sector, many respondents identified the need for good technical abilities in engineering design, HVAC and controls, energy modeling, and industrial processes.

There may be an important opportunity for educational institutions in the region to offer more applicable energy efficiency training. When asked if educational programs were keeping up with 
changing energy efficiency technology and emerging clean-tech fields, respondents gave universities, community colleges, trade schools, and union training programs average scores between 2.5 and 2.8 (where 1 = strongly disagree and 5 = strongly agree), with a rating of 2 or 3 given by over $70 \%$ of employers for every training program type. Employers also expressed strong interest in internships for students that will soon enter the job market. Over $60 \%$ of the firms already sponsored interns, and 70\% expressed an interest in participating in a NEEC internship placement program. Training and other workforce development programs will become increasingly important if the sector grows over the next five years as these companies expected. New positions also will open due to retirement of current employees. These firms estimated that almost $14 \%$ of their skilled employees will retire in the next five years.

\subsection{Connecticut Employer Survey}

Navigant Consulting conducted an assessment of energy efficiency employers in Connecticut during the first quarter of 2009 for the Connecticut Clean Energy Fund (CCEF) and the Connecticut Energy Efficiency Fund (CEEF). Navigant identified 97 key businesses in the state; they interviewed 37 directly and researched the others in detail.

\subsubsection{Employer Characterization}

The businesses in Connecticut generally offer products and services similar to those found in the other three regional employer surveys, but the frequency of each service offered was not reported. Instead, the Connecticut study focused on types of employees and the sectors served by the firms. The big difference between the Connecticut results and those from other studies was the strong presence of retail and wholesale businesses in the study's results: $20 \%$ of jobs were in these areas (see Table 15).

Table 15: Percentage of Jobs by Employee Job Type in Connecticut Energy Efficiency Firms

\begin{tabular}{|l|c|}
\hline \multicolumn{2}{|c|}{ Job Types } \\
\hline Retail/Wholesale & $\mathbf{2 0 \%}$ \\
\hline Installations & $\mathbf{1 8 \%}$ \\
\hline $\begin{array}{l}\text { Management and } \\
\text { Administration }\end{array}$ & $\mathbf{1 7 \%}$ \\
\hline $\begin{array}{l}\text { Sales and Business } \\
\text { Development }\end{array}$ & $\mathbf{1 6 \%}$ \\
\hline Engineering & $\mathbf{9 \%}$ \\
\hline Manufacturing & $\mathbf{6 \%}$ \\
\hline Research & $\mathbf{4 \%}$ \\
\hline Utility & $\mathbf{3 \%}$ \\
\hline Operations and Maintenance & $\mathbf{3 \%}$ \\
\hline Other & $\mathbf{1 \%}$ \\
\hline
\end{tabular}

This is likely due to an emphasis on this sector in the research design of the Connecticut study, which included large retailers such as Home Depot and Walmart in the market assessment, unlike the other regional employer surveys. 
In other ways, the Connecticut results mirror those from other parts of the country. The 97 firms employ 2,675 people based in-state. This includes all jobs within each firm, not just those with efficiency-specific roles. This is about 28 people per firm, compared to about 27 in-state staff per firm in Massachusetts, and about 31 in-state staff per firm in California. These firms generate $\$ 137$ million that goes directly to job employment income, which is about $\$ 51,000$ per employee. The total revenue reported for these firms is \$565 million, divided as shown in Figure 29.

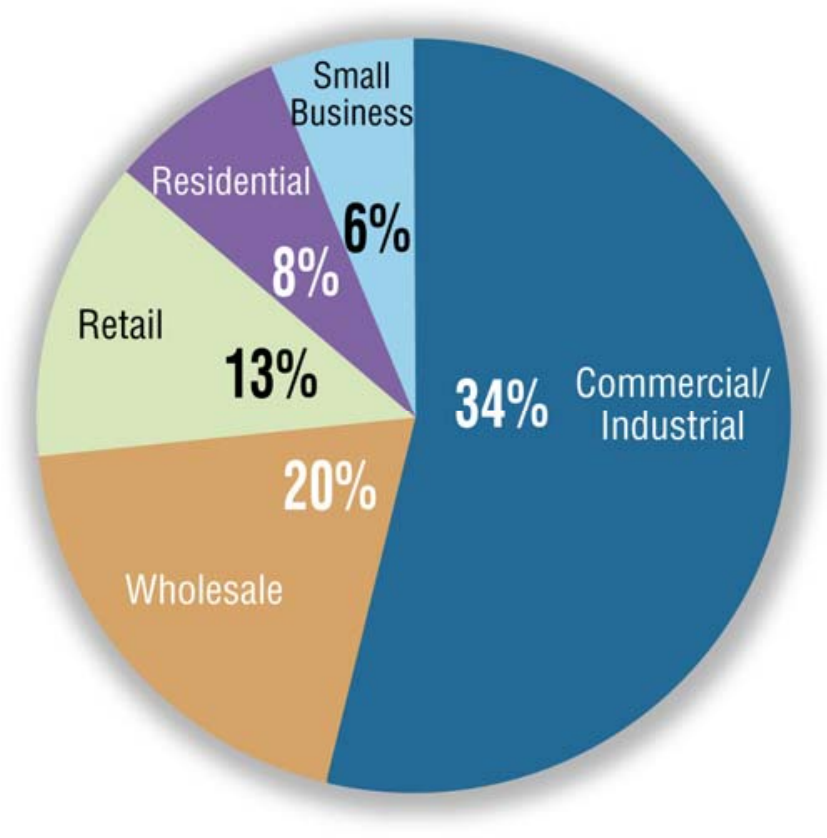

Figure 29: Revenue by Sector Served for Connecticut Energy Efficiency Businesses

Firms that serve C/I clients account for $53 \%$ of the revenue earned by energy efficiency firms, while firms that serve the residential market account for $8 \%$ of total revenue. In terms of the number of jobs, C/I firms account for 52\% of energy efficiency jobs in Connecticut, compared to $16 \%$ for firms that target the residential market.

\subsection{Comparative Analysis of State or Regional Surveys of Employers on Energy Efficiency Services}

We highlight the following trends based on our review and analysis of these four surveys of employers regarding energy efficiency services workforce size, composition, and training needs:

- Most firms providing energy efficiency services are extremely small (often under 10 people), with a few very large firms. For example, well over $75 \%$ of firms in California, the Pacific Northwest and Massachusetts each has 100 or fewer employees, and at least 34\% of firms in each state have 10 or fewer employees. These employers 
tend to include a large number of small consulting firms and startups, and a few very large engineering firms and ESCOs.

- These firms' operations appear to frequently span more than one state. Responses to a question which asked directly how many of their employees are based in-state, indicated that the average number of employees per firm in Massachusetts is 27 (21\% of the firms' average total employees) and the average in Connecticut is 28. Most of these multi-state firms are likely the large engineering and ESCOs.

- The employers often serve multiple customer market segments. In California, the employers serve the following sectors: $76 \%$ commercial, $47 \%$ industrial, $50 \%$ public or institutional, and 70\% residential. In the Pacific Northwest these numbers are: $86 \%$ commercial, $60 \%$ industrial, and $39 \%$ residential (public or institutional not asked). If you look at just the $\mathrm{C} / \mathrm{I}$ market versus the residential market in Connecticut, revenue is $88 \%$ and employment is $76 \%$ from C/I (including small business), versus 12\% and $24 \%$ respectively in the residential market. California is the only state that shows relatively strong activity in the residential sector compared to other market sectors. However, this result simply may be a result of the types of firms that were targeted and/or responded to each regional survey.

- Expectations for growth are high, perhaps particularly in the energy efficiency portion of a firm's business. In Massachusetts, most employers expect greater than $10 \%$ growth in revenue and an average $9 \%$ increase in employees by mid-2010. In the Pacific Northwest, most employers expect revenues to grow at an annual rate of 5-7\% to 2013. In California, employers expect a $20 \%$ growth in energy efficiency-specific jobs in 2010 , versus $2 \%$ growth for all job categories. This distinction between growth in energy-efficiency specific jobs and all job categories is important for workforce development and training, and is not captured by the other three employer surveys. ${ }^{46}$

- "Premium" energy efficiency jobs are likely only a fraction of the total employees in many firms. The eight energy efficiency-specific jobs identified at California firms make up only $28 \%$ of the total jobs at these firms. Energy efficiency firms comprise a variety of job types, and in order to inform the estimates of the overall number of energy efficiencyspecific jobs and the need for training programs in these specific occupations, it is important to recognize the fact that not all jobs at these firms require energy efficiencyspecific skills.

\footnotetext{
${ }^{46}$ The California survey was completed between December 2008 and July 2009. The Massachusetts survey was conducted in January 2009. The Pacific Northwest survey was conducted for 2 months during summer 2008. The Connecticut survey was completed during the first quarter of 2009. Employers' growth expectations may have been influenced by the timing of the survey, given the developing recession.
} 
- Additional energy efficiency training is needed. In California, 56\% to $73 \%$ of employers (depending on the job category) have "Great" or "Some” difficulty in hiring qualified energy efficiency-related employees. In the Northwest, $70 \%$ of employers "could not or sometimes could not find qualified applicants." In Massachusetts 24\% of employers were not able to fill positions with qualified candidates.

The survey results highlight the make-up and size of the EESS in various states and regions and provide insight into the types of training and support that are valued by employers looking to provide energy efficiency services. 


\section{Meeting Energy Efficiency Service Workforce Needs}

As previous chapters demonstrate, we can expect increased demand for a significantly expanded, well-trained, and experienced EESS workforce. Needs range from engineers and architects to design energy-efficient building systems and HVAC technicians to install systems and optimize efficiency, to program and construction managers to administer and oversee development of energy efficiency programs and projects. To understand the gaps in the EESS, we included questions in our surveys to assess the respondents' perceptions of issues their organizations face in hiring, retaining, and training their staff; this chapter summarizes results from our interviews on these topics.

\subsection{Is It Difficult to Hire the Right People?}

As illustrated by our summaries of four recent state and regional employer surveys on energy efficiency (see Chapter 5), many EESS firms reported difficulty in hiring people. Survey respondents reported that during 2007 and 2008, it took two to three months to fill entry-level positions in the EESS. Moreover, management positions requiring at least 10 years' experience and positions requiring engineering experience with high-efficiency technologies are the most difficult positions to fill; survey respondents noted that many positions take three to five months to fill, but that it can take up to 15 months to hire an engineer with managerial skills and energy efficiency experience. One company gave the example of receiving 80 applications for a seniorlevel position only to find that only five applicants could pass the initial screening. Another company noted that they were planning to take several years to find a suitable candidate for a senior position leading their energy efficiency group.

Filling experienced positions often occurs by hiring from other firms. Program implementation contractors are very concerned about losing experienced staff to Overall, respondents believe there are challenges hiring into the EESS for any position other than entry-level. competitors, and three of the 23 respondents expressed reluctance to provide staffing information for fear it would somehow be misused. Many respondents stated they believe that hiring from other firms is reaching a limit as the rate of growth increases in the EESS; the total number of experienced personnel needed exceeds the existing workforce. While program implementation contractors expressed the most concern, the most common examples involved program implementation contractors hiring from program administrators, which occurs largely because program administrators have less competitive salaries. This phenomenon is most pronounced in regions with high costs of living (e.g., the Northeast and California).

In contrast, building and construction industry contractors said they did not hire for energy efficiency skills and reported hiring from a variety of sources: former manufacturing workers, people with military experience, graduates of local community colleges and technical trade schools, various web sites such as Monster.com and CareerBuilder, local building associations, and employment agencies. For residential construction there was no lack of potential employees due to the limited training requirements; residential contractors reported that they hired "from anywhere" or "by word of mouth." 
Survey results revealed that general contractors, builders, and remodelers typically come to their positions after working in the industry for several years and gaining sufficient experience to feel they can manage projects. There is little training available in technical schools or colleges; experience is the primary teacher. Among survey respondents who were members of building associations, several noted that the demand for green building is leading to a change in the industry and that younger contractors are developing more skills associated with green building than those who have been in the business a long time. None of the respondents could quantify this rate of change, but the current participation rate in green certification programs among building association members was reported as less than $5 \%$ of the industry.

For equipment installation contractors, the experience of hiring is affected by the level of unionization. Those areas with a highly unionized building trades workforce report hiring out of apprenticeship programs. In “open-shop” states or states with a less unionized building trades workforce, employers place ads to find applicants. While general hiring seems satisfactory for building and construction contractors, several respondents from industry associations mentioned anticipated future shortages due to retirements (see Section 6.3).

Union contractors and labor union respondents reported some difficulty recruiting qualified applicants into apprenticeship programs. They have many applicants, but a much smaller number who can pass the basic skills and drug screening tests. In a similar vein, several contractor association respondents expressed dismay over a lack of interest in jobs that are physically demanding, suggesting that the allure of "white collar" service jobs limits the pool of applicants seeking apprenticeships. In New York, the Board of Cooperative Education Services (BOCES) provides training through community colleges, which contractors say helps meet building and construction industry needs. In Connecticut, contractors reported that there was a workforce shortage in the residential construction industry in 2004-2006 that was addressed by workforce development efforts. Such efforts are not found in all states, but do point to a mechanism that could aid the EESS.

\subsection{Is There an "Aging Workforce” Issue for the EESS?}

At the outset of this project, one of our hypotheses was that the EESS workforce was aging and that soon a wave of retirements would leave a void in the EESS workforce. Recent studies of the utility industry reported that $44 \%$ of the current utility sector workforce will reach retirement age in the next five to ten years (Stern 2008). Mary Miller, Vice President of Human Resources at the Edison Electric Institute, noted that, coincident with these pending retirements, many utilities expect a need to expand staffing by 50\% to meet increasing demand for power (Stern 2008).

Pacific Gas and Electric (PG\&E) in California, a program administrator, also identified retirement as an issue. PG\&E has more than 20,000 employees; $42 \%$ of their union employees and $50 \%$ of their management are eligible to retire by 2014 (Opalka 2008). In response, electric and gas utilities across the United States created the Center for Energy
Retirement is not currently a concern for Program Administrators or Program Implementation Contractors; however, the building and construction industry is facing substantial changes in the workforce due to retirements between 2015 and 2025. 
Workforce Development (CEWD) to work with educational institutions, labor groups, and others to identify ways to promote jobs and careers in the utility sector (Center for Energy Workforce Development 2008).

Given these recent studies, it seemed logical that the EESS might also be facing retirement of its experienced work force. However, among the 23 program administrators that provided an estimate of the percentage of their workforce projected to retire in five years (by 2014), the mean was $15 \%$. Among program implementation contractors $(n=17)$ the mean percentage expected to retire in five years (by 2014) was just 6\%, while for ESCOs $(n=9)$ less than $5 \%$ of their workforce were projected to retire in five years. Respondents in all groups further qualified their responses to retirement questions, indicating that retirement was not a big concern. Rather, retaining existing staff, managing the growth of the efficiency department, and finding qualified staff knowledgeable about efficiency were their dominant personnel concerns.

In contrast, aging workforce and loss of large pool of qualified workers due to retirement is viewed as a problem among the building and construction industry. Respondents from building and construction industry association members reported much higher percentages of association members older than 50 and thus nearing retirement in the next five to ten years.

Builders/remodelers and mechanical and electrical trades people had the largest share of workers nearing retirement (38\% to 44\%, see Figure 30). At the lower end, our survey found $28 \%$ of energy engineers were over 50 years of age.

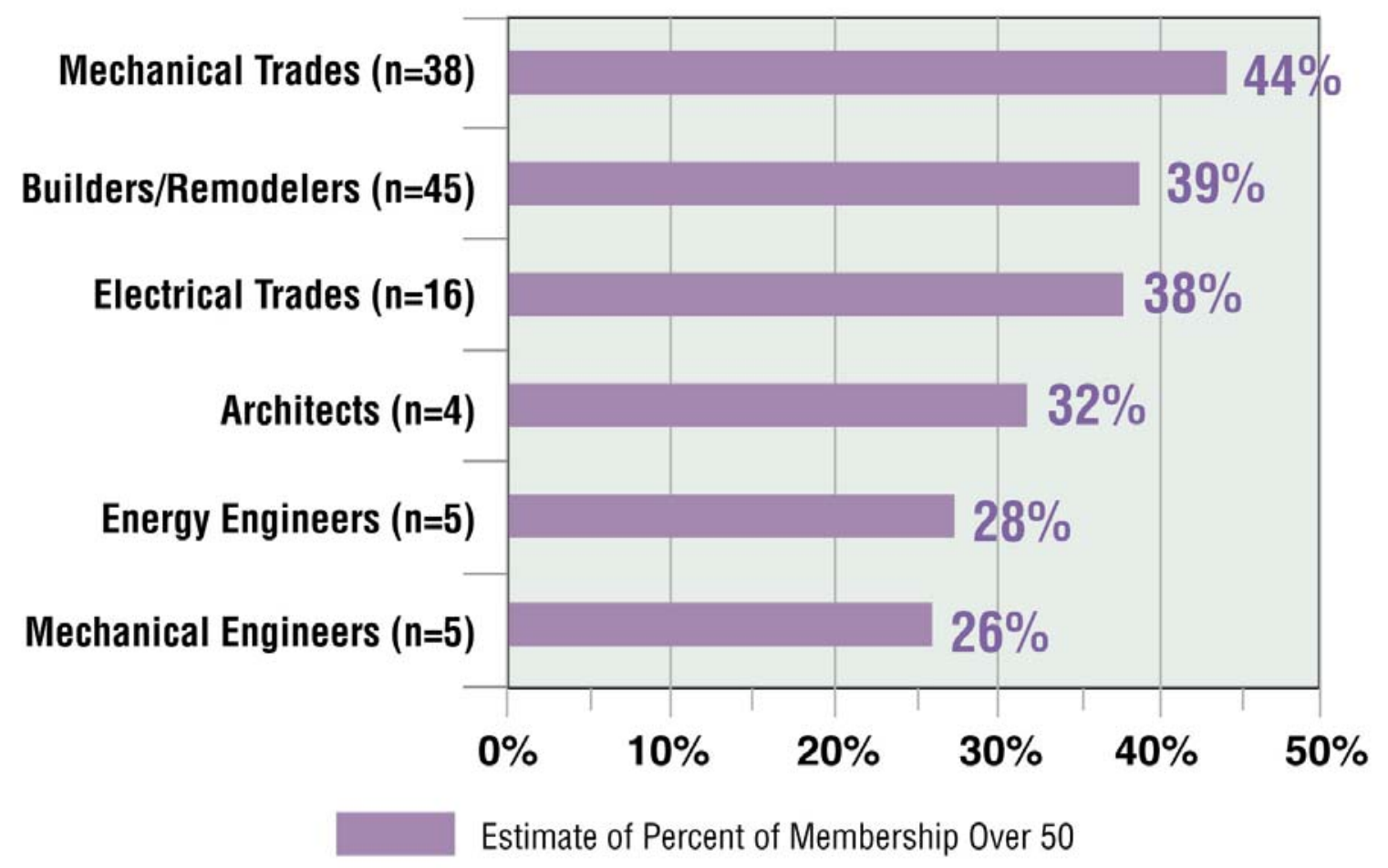

Figure 30: Building Industry Workforce Older Than 50 
A recent survey of 978 members of the Association of Energy Engineers (AEE 2009a) suggests that retirement could be an even more significant issue than we found in our surveys of professional engineering associations. The AEE survey indicated that over $61 \%$ of the respondents have over 21 years experience in the business while only $14 \%$ have 5-15 years of experience (see Figure 31). This result indicates a bimodal distribution in the amount of experience of practicing energy engineers. We believe that this phenomenon is driven in part by the influence of policy-driven funding cycles. Notably, the period 1996-2006 there was reduced public policy support for energy efficiency (DOE 2007). Due to this situation, there are very few mid-career energy engineers who can take over senior positions as older engineers begin to retire. This distribution and the effect of shifting funding cycles have been noted for EESS occupations in other studies (Peters 2009; Nadel 2009).

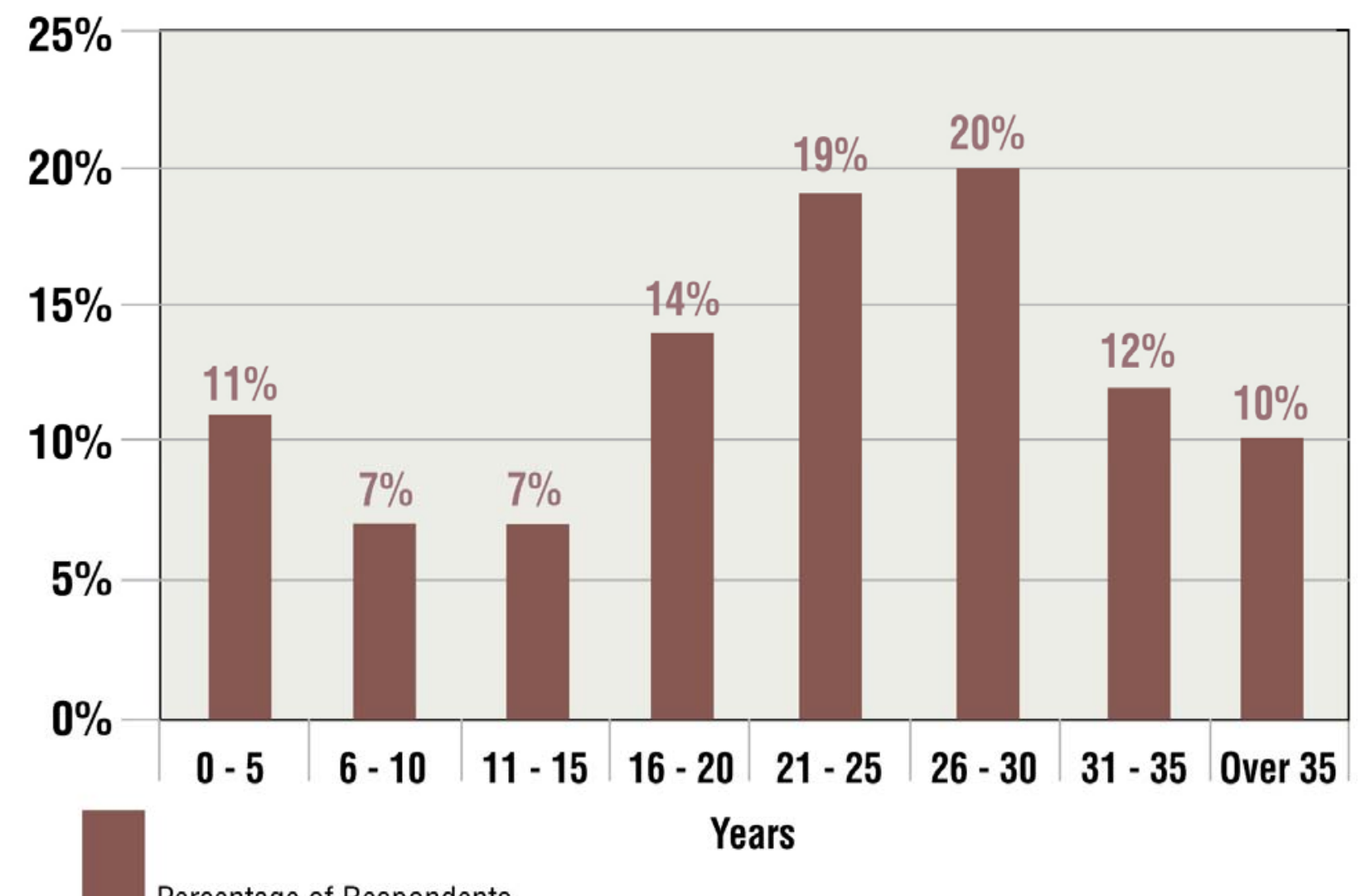

Source: Association of Energy Engineers (2009).

Figure 31: Energy Engineers: Years of Professional Experience

To summarize, the energy efficiency program administrator and program implementation contractor organizations interviewed for this study did not view retirement of their existing workforce as a major concern, now or in the next five years. However, the challenge of finding managers and engineers with

The bi-modal age distribution of staff for EESS firms, may partially explain the current challenge in hiring experienced managers. experience is a significant issue. The bi-modal distribution observed in these firms suggests that in the next few years there could be a problem having sufficient staff to train and manage the 
new entrants, especially as those at the upper age range of the distribution begin to retire. As that happens, retirement could become a larger concern.

\subsection{Are There Enough Engineers for an Expanding EESS Workforce?}

Program administrators, program implementation contractors, and ESCOs that work with C/I customers indicate that engineering talent is difficult to find. Survey respondents reported that engineers with efficiency knowledge or experience are relatively nonexistent. As a consequence, these companies and organizations often are willing to hire any engineer with technical aptitude, communication skills, and some engineering experience. This explains the results in Figure 32, which shows that about $55 \%$ of program administrators and program implementation contractors indicated that they were most interested in hiring energy engineers. We probed those respondents who didn't check energy engineers as a preferred engineer hire and found that most of these survey respondents were interested in hiring energy engineers, but that they are much harder to find than other engineers.

Given that reality, program administrators and program implementation contractors indicated that their top preference is to hire mechanical engineers (see Figure 32), but when not available, respondents indicate they hire from other engineering disciplines including electrical (especially for utility program administrators), chemical, agricultural, or civil engineers. ${ }^{47} \mathrm{~A}$ memo from Johnson Controls Inc. (JCI) to the DOE Industrial Technologies Program also reported a lack of trained energy engineers emerging from engineering schools other than through the Industrial Assessment Centers (DOE Industrial Technologies Program 2008).

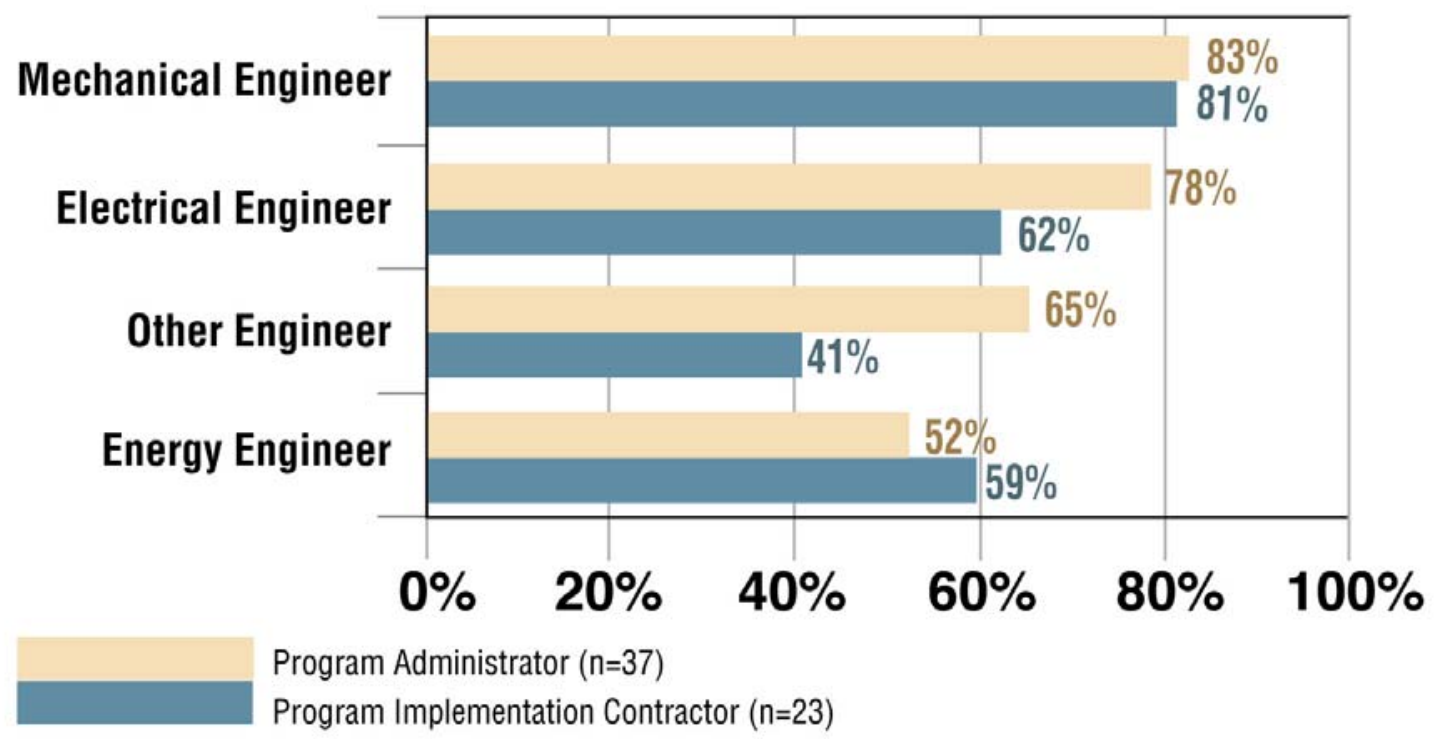

\footnotetext{
${ }^{47}$ We asked the following question. "What types of engineers are you typically most interested in hiring for energy efficiency work? (1) Energy Engineers, (2) Mechanical Engineers, (3) Electrical Engineers, (4) Other Engineers. Respondents were also asked to comment on other types of engineers they hire.
} 


\section{Figure 32: Preferred Engineers for Program Administrators and Implementation Contractors}

The demand for engineers with knowledge of energy efficiency is currently met by hiring other types of engineers and training them on the job. This practice may not be sufficient as the EESS workforce demand increase in the future. Many industries compete for engineering talent and for engineers to seek positions in the EESS they need to know the field exists. Table 16 displays the engineering disciplines recognized by the U.S. Bureau of Labor Statistics (BLS) as of 2006 and the number of engineers

Until 2009, energy efficiency engineering was not included in the Bureau of Labor Statistics Occupational Handbook as a job category. employed in each discipline. Many disciplines align with specific occupations: a degree in aerospace engineering can lead to a job with an airline manufacturer, a defense contractor, or a government agency that engages with the aerospace industry. Energy efficiency is yet to be recognized as an engineering discipline by the BLS, despite the Association of Energy Engineers having over 9,500 members (AEE 2009).

Table 16: Number of Employees by Engineering Discipline: 2006

\begin{tabular}{|c|c|c|c|}
\hline Engineer Discipline & Employees (2006) & $\begin{array}{c}\text { Percent of } \\
\text { Total }\end{array}$ & Median Salary (\$) \\
\hline Aerospace Engineers & 90,000 & $6 \%$ & 87,610 \\
\hline Agricultural Engineers & 3,100 & $0 \%$ & 66,030 \\
\hline Biomedical Engineers & 14,000 & $1 \%$ & 73,930 \\
\hline Chemical Engineers & 30,000 & $2 \%$ & 78,860 \\
\hline Civil Engineers & 256,000 & $17 \%$ & 68,600 \\
\hline Computer Hardware Engineers & 79,000 & $5 \%$ & 88,470 \\
\hline Electrical Engineers & 153,000 & $10 \%$ & 75,930 \\
\hline Electronics Engineers (except Computer) & 138,000 & $9 \%$ & 81,050 \\
\hline Environmental Engineers & 54,000 & $4 \%$ & 69,940 \\
\hline $\begin{array}{l}\text { Health and Safety Engineers (except Mining Safety } \\
\text { Engineers and Inspectors) }\end{array}$ & 25,000 & $2 \%$ & 66,290 \\
\hline Industrial Engineers & 201,000 & $13 \%$ & 68,620 \\
\hline Marine Engineers and Naval Architects & 9,200 & $1 \%$ & 72,990 \\
\hline Materials Engineers & 22,000 & $1 \%$ & 73,990 \\
\hline Mechanical Engineers & 227,000 & $15 \%$ & 69,850 \\
\hline $\begin{array}{l}\text { Mining and Geological Engineers ( including } \\
\text { Mining Safety Engineers) }\end{array}$ & 7,100 & $0 \%$ & 72,160 \\
\hline Nuclear Engineers & 15,000 & $1 \%$ & 90,220 \\
\hline Petroleum Engineers & 17,000 & $1 \%$ & 98,380 \\
\hline All Other Engineers & 170,000 & $11 \%$ & 81,660 \\
\hline Total Number of Engineers & $1,510,400$ & & \\
\hline
\end{tabular}

Source: Bureau of Labor Statistics (2008). 
A few of our survey respondents noted difficulty competing for engineers with large international firms or high-tech computing and aerospace companies that offer higher salaries and perks such as international travel. At the same time, there is concern that the total number of engineers receiving degrees cannot keep pace with the need. For instance, Leon (2005) reports that U.S. defense spending correlates with the number of engineering degrees conferred in the U.S. Figure 33 shows trajectories for defense spending and conferred engineering degrees in the U.S. from 1966 to the 2006. Leon concludes that the total number of engineering degrees being granted is no longer keeping pace with the need and advocates for more investment in research and development and science and engineering curricula.

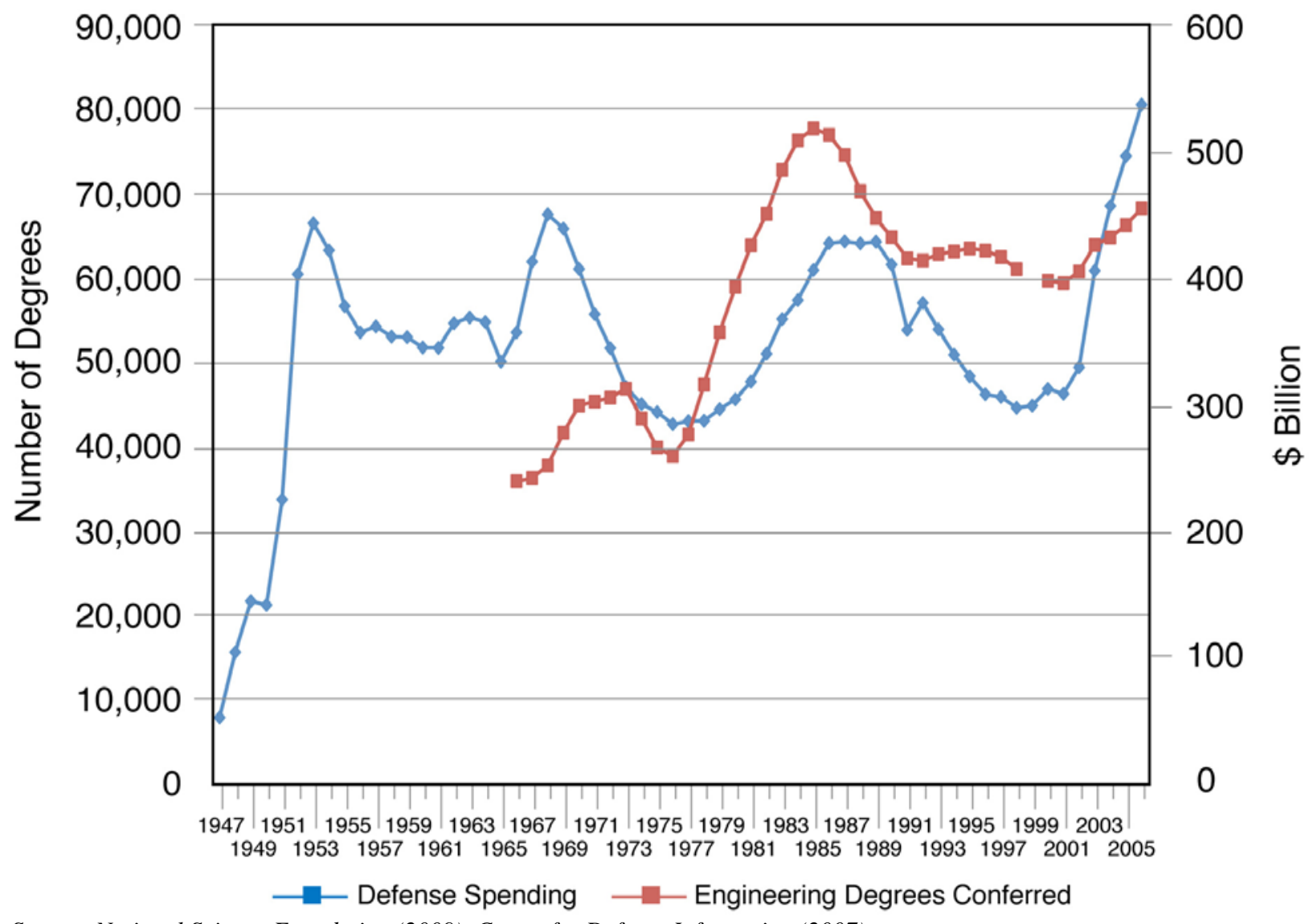

Source: National Science Foundation (2009), Center for Defense Information (2007).

Figure 33: U.S. Defense Spending and Conferred Engineering Degrees

The energy industry generally also has experienced shifts in funding and demand. An Oak Ridge National Laboratory (1982) study of the scientists and engineers working in the energy field from 1976 to 1980 found that as Federal funding increased in coal exploration there was an increase in scientists and engineers in that field. Similarly, as fossil fuel prices rose in the 1970s, there was an increase in the number of engineers and scientists employed in the energy field, and between 1976 to 1980 there was a 70\% increase in the number of bachelor's and master's graduates in energy-related activities (Bell 1982). 
Nuclear engineering also has seen fluctuations in funding, hiring, and demand. A 2008 study found that most nuclear engineers in the field are between the ages of 45 and 65, while there are few nuclear engineers between the ages of 32 and 45, and a small peak of nuclear engineers younger than 32 years of age. These distributions correlate with funding cycles for nuclear energy (Prelaw 2008).

Bell (1982) reported that the energy industry was able to keep up with the demand for engineers by hiring from related fields. Petroleum companies preferred petroleum or geological engineers, yet they hired mechanical engineers and trained them in petroleum engineering. The results of our interviews suggest that a similar phenomenon is happening in the EESS. While firms desire energy or mechanical engineers, program administrators, program implementation contractors, and ESCOs reported that they hire any engineer with interest in energy efficiency and build upon the engineer's technical aptitude through on-the-job, industry-specific training. Several of the larger program implementation contractors, and ESCOs we spoke with noted that they have no difficulty attracting engineering talent that they could train. In contrast, smaller firms indicated that they find it more difficult to recruit, as they do not have similar recruitment or training resources.

Are U.S. universities conferring too few engineering degrees? Between 1966 and 2006, the number of engineering graduates grew from 35,826 to 68,121 , an increase of $90 \%$. During the same period, the number of bachelor's degrees conferred rose from 524,008 to 1,473,735, an increase of $180 \%$ (National Science Foundation 2008). Thus, the relative percentage increase in number of students with bachelor's degrees is roughly twice the rate of increase in the number of engineering graduates. However, some studies suggest that it is not possible to conclude that there is a shortage of engineering talent.

For example, Brown and Linden (2008) concluded that there are insufficient engineers in the United States because salaries are not rising (which would

Competition for Engineers

The semiconductor industry employs the largest number of engineers and offers the highest salaries, thereby attracting the largest share of engineers with advanced degrees. Since the mid-1990s, the percent of U.S. citizens pursuing advanced degrees in engineering has steadily declined (see Figure 34). In the future, achieving an adequate pool of engineers with advanced degrees and good English communication skills may be a challenge for the EESS.

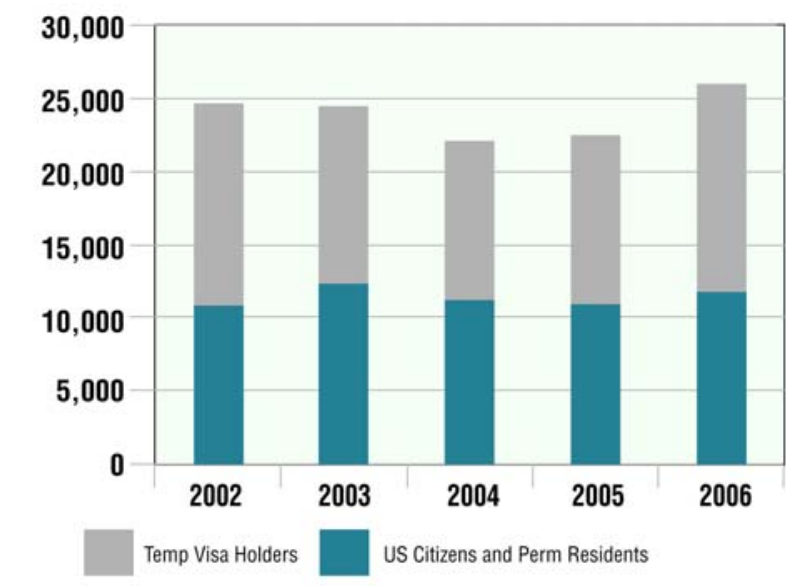

Source: National Science Foundation, 2008.

Figure 34: Number of U.S. Graduate Engineering Degrees by Citizenship Status indicate a lack of supply) and because there are more trained engineers than there are employed engineers. They found that the perceived lack of engineering talent occurs for industries that seek 
recent graduates with advanced degrees in the most cutting-edge areas of engineering (e.g., semiconductors and computers), or in fields that prefer engineers with advanced degrees and U.S. citizenship (defense). Meanwhile, experienced engineers in these industries are not retained as the technologies they are most experienced with are replaced by new ones, resulting in a larger number of trained engineers than positions.

Two program implementation contractor respondents said that defense, semiconductor, nuclear, and software industries were the EESS's primary competitors for engineering talent because the EESS also needs engineers with advanced degrees and good communication skills.

Regardless of the number of engineers generally available, most survey respondents confirmed that it is hard to find engineers to work in the EESS. To be effective, EESS engineers need training in fluid dynamics and thermodynamics, knowledge of building energy systems, an interest in optimizing the performance of existing HVAC, refrigeration or industrial process systems, and good communication skills for working with customers. The most likely source for new EESS engineers is to transition engineers from other fields into energy efficiency. In addition, recognizing energy engineering as an engineering discipline will help the recruitment and tracking of engineers with energy expertise.

\subsection{Are There Enough Experienced Managers?}

Hiring managers who are knowledgeable about energy efficiency is probably the largest potential bottleneck in the EESS workforce. According to most respondents, the challenge of finding experienced managers is more difficult than finding engineering talent. While the EESS has grown significantly in the past four years, both in terms of program administrator budgets (CEE 2008) and ESCO revenues (Goldman and Hopper 2007), according to our respondents, the number of experienced manager-level staff has not increased at a similar rate.

Respondents commonly stated that the number of management positions in their organizations had stayed constant in recent years while their organizations hired more entry-level positions. Some respondents stated that the primary limitation on program implementation contractor firm growth or expanded program offerings by program administrators is the lack of managementlevel applicants with experience in energy efficiency.

One program implementation contractor stated that it is "almost impossible to find someone with energy efficiency program management experience.” People with this knowledge and experience are highly valued by the industry. They also are vital mentors for the next generation of managers in the EESS. This issue may become increasingly important in the future as the EESS workforce demand increases because 
there are few schools and training centers that offer curriculum focused on energy efficiency. On-the-job mentoring currently fulfills EESS training needs.

There also is a gap between senior- and entry-level jobs throughout the EESS. It is this gap that poses a significant problem because of limited mid-career staff that can both work with recent hires and be groomed for senior positions.

The problem also is relevant for low-income weatherization organizations, where, according to Adams (2009) there is limited senior staff: "Due to state budget shortfalls, the existing technical and administrative monitoring capacity at the state level is severely understaffed." Addressing this gap will not be easy. It is difficult to impart years of experience through training. While managers from other industries can provide some capacity, having experience in energy efficiency that is deep enough to provide guidance to others will be necessary for the EESS to remain effective.

\subsection{Are There Enough Trainers?}

Given the widespread need for additional training activity as the EESS grows, a key question is whether there are enough trainers to train the entrants to the EESS.

Comments from survey respondents who are trainers noted that many trainers are among those who are older than 50. Among trades people we spoke with those who do training, and we heard several comments about the difficulty of recruiting younger trades people to become trainers because it requires more coursework to obtain and retain sufficient certifications to be trainers. Among program administrators and program implementation contractors, experienced managers do the training and are over 50. While program implementation contractors and program support contractors rarely have mandatory retirement ages, the sheer volume of training required could exceed the number of experienced managers available to do the training. As one experienced program implementation contractor stated, "This won't be a problem in 10 years, but it is certainly a problem today."

As part of this study, we interviewed 32 contacts involved in two-year, four-year, and specialty training organizations for the building and construction industry and EESS. ${ }^{48}$ Our investigation focused on identifying and assessing programs that currently offered some explicit training in energy efficiency as defined by the DOE's Energy Efficiency and Renewable Energy Program, the International Energy Program Evaluation Conference, the American Society of Mechanical Engineers, and a group of experienced energy efficiency experts. We attempted to collect information from them about the number of certificates and degrees being awarded to participants in energy efficiency-related training and education opportunities. Our results suggest that there are not enough certificates or degrees being awarded

\footnotetext{
${ }^{48}$ The results of these interviews will be discussed in the second report in this series.
} 
to meet the growing need. Our respondents identified 20 certificate or degree programs that specifically addressed energy efficiency. These ranged from two-day trainings to Ph.D. programs. These 20 programs awarded approximately 3,400 certificates or degrees in 2008 to a range of graduates of four-year and two- year college programs, builders, mechanical contractors, architects, and engineers. Considering that the size of the entire building industry is close to 7 million people, ${ }^{49}$ formal energy efficiency training affects a small fraction of the workforce. We also found that energy efficiency training is being expanded, educational programs are under development, and more certificates and degrees will be developed and awarded by 2015. In the meantime, the need to expand training programs and inform the workforce that there are jobs in the EESS should be a key focus of workforce development efforts.

\subsection{Near-Term Increases in the Energy Efficiency Workforce}

An important finding that emerged from our interviews was the need to inform the building and construction industry workforce that the EESS is expanding. Program administrators and program implementation contractors have fairly clear expectations for growth of energy efficiency services and the likely effect on their workforce needs. For example, in response to a question that asked respondents to estimate the size of their organizations' workforce involved in energy efficiency by 2010, we found that in aggregate, program administrators estimated that their staff would grow about $19 \%$ by 2010 and that program implementation contractors expected that their staff will increase by about $64 \%$.

In contrast, fewer than $50 \%$ of contacts in design, engineering, and building and construction industry associations could estimate the percent of the current workforce affected by energy efficiency. Of those who could, the design and engineering associations perceived energy efficiency to have a dominant or moderate influence on their current activities, while other building and construction association respondents saw only a moderate or limited level of influence (see Figure 35) on their activities.

\footnotetext{
${ }^{49}$ This is the sum of all occupations in the following NAICS codes in 2007: 236100 Residential Building Construction, 236200 Nonresidential Building Construction, 238200 Building Equipment Contractors, 238300 Building Finishing Contractors, 238900 Other Specialty Trade Contractors, and Architectural, and 541300 Engineering and Related Services.
} 


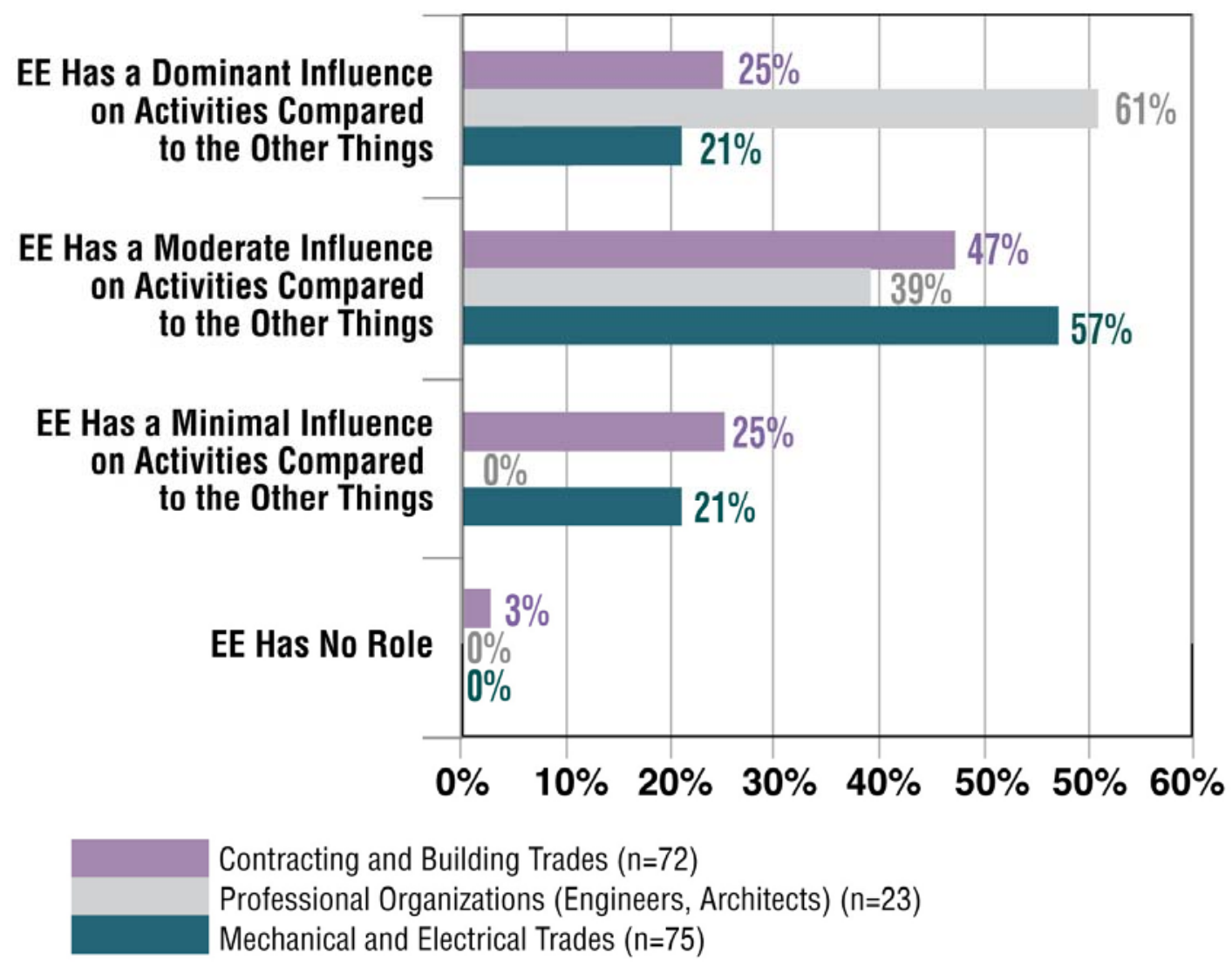

Figure 35: Influence of Energy Efficiency on the Building Industry

Less than $50 \%$ of the building and construction industry association contacts were able to estimate the current role of energy efficiency on their business, nor could many estimate the likely increase in their business if there were an increase in funding for energy efficiency. For respondents who could make an estimate, those working in the residential sector anticipated a somewhat larger effect on their business than respondents primarily working on commercial and industrial buildings. Yet our analysis suggests that the funding and workforce effects likely will be about equal for the two sectors.

Those building and construction industry associations that were aware of these changes tended to be located in areas of the country with active energy efficiency programs or to represent a national organization or national labor union rather than a local building and construction association.

We draw the following conclusions from these survey responses:

1) Most firms in the building and construction industry that will be needed to implement energy efficiency solutions are currently unaware of the pending increase in funding for energy efficiency. 
2) Not surprisingly, the capacity is not yet developing in the building and construction industry to provide energy efficiency services.

3) National representatives of building and construction industry associations need to educate their state and local organizations on the policy and market drivers that are leading to significant increases in energy efficiency spending so they can inform their members of the need to develop the necessary skills to provide energy efficiency-related services to meet the coming demand.

4) Program administrators and program implementation contractors are aware of policy drivers that significantly influence spending on energy efficiency and are developing responses and capability to address future growth. 


\section{Conclusions}

There is a growing commitment to reduce energy consumption and address concerns about global climate change in the U.S. This commitment is leading to new policy efforts and funding for improving the energy efficiency of buildings. The energy efficiency services sector (EESS) is that portion of the workforce that implements energy efficiency efforts in response to policy initiatives and market demand for improved energy performance. This report addressed the size and types of jobs in the EESS, projections for growth in response to policy initiatives and market demand, and current perceptions regarding the ability of the EESS workforce people to scale up to meet demand.

\subsection{Current EESS Workforce}

We estimate the EESS workforce in 2008 comprised 114,000 person-years of employment (PYE) in newly created or transformed occupations, which represents an estimated 380,000 individuals working full- or part-time on energy efficiency activities.

Ratepayer-funded energy efficiency efforts currently constitute about 30\% of the estimated EESS person-years. This employment includes the staffs of program administrators, program implementation contractors and program support contractors as well as the building and construction professionals and trades people that design and install energy efficiency projects equipment and appliances and provide services that are part of ratepayer-funded energy efficiency programs that are developed through ratepayer-funded energy efficiency programs. Federal- and state-funded low-income weatherization assistance efforts currently constitute about $5 \%$ of the total person years of employment in the EESS. Energy efficiency market activity of ESCOs constitutes about $10 \%$ of the total person-years, including ESCO staff and the professionals and workers they hire from the building and construction industry to implement ESCO projects. Efficiency activity related to building envelope insulation and mechanical insulation comprises just over 50\% of the estimated EESS PYE.

\subsection{EESS Workforce Growth to 2020}

To project the requirements for the future EESS workforce, we used an estimate of future spending on energy efficiency based on policies in place at the time of the study. The possible effects of Federal carbon legislation or a Federal energy efficiency portfolio standard were not included in the estimates. Our study concludes that anticipated spending on energy efficiency by 2020 in the high-growth scenario will require a workforce that is at least four times larger than that in place in 2008.

We believe the high-growth scenario to be most likely; however, the EESS workforce will grow by at least two-fold between 2008 and 2020 even under our low scenario (whether considered in terms of PYE or number of individuals engaged in EESS activities). The anticipated increase means people currently employed in the EESS will need additional energy efficiency-specific training to keep abreast of developments in the field and new people will need to be introduced to the sector and adequately trained to implement energy efficiency in a reliable and cost- 
effective manner. Clearly, the current workforce is too small and will be challenged to meet even near-term needs associated with ARRA funding.

In the high-growth scenario, the EESS could reach nearly 1\% of the national workforce by 2020 and may comprise as much as $3 \%$ of the relevant building and construction industry, which is equivalent to nearly 384,000 person-years of employment and involve $~ 1.3$ million individuals engaged in full-time or part-time work.

The largest share of EESS workforce growth (fully 78\% percent of the 2020 high scenario) will be in the building and construction industry, which is defined as design, engineering, and building and construction firms (including insulation installers).Yet, much of the building and construction industry (outside of the design and engineering community) is unaware of this pending growth and is focused primarily on more immediate concerns driven by the severity of the economic downturn in the construction industry (e.g. high unemployment, retaining existing jobs.

\subsection{Preparing for an Expanded EESS Workforce}

Program administrators, program implementation contractors, and program support contractors are aware of the potential growth in the EESS and are hiring, training, and growing their staff. Program administrators sometimes face restrictions on their ability to rapidly increase their workforce rapidly, due to company, legislative or regulatory constraints (e.g., hiring freezes within the utility, budget shortfalls in states that lead to hiring freezes, or limits placed by state public utility commissions on administrative budgets). In these situations, program administrators typically turn to program implementation contractors and support contactors who have the flexibility to expand or reduce as needed. Other sectors are less prepared for growth.

\subsubsection{Building and Construction Industry}

There is a need to inform the building and construction industry of the pending growth in the energy efficiency market. Today, the building and construction industry is focused on the effects of the economic downturn, but in the long term, there will be a need for skilled contractors and trades people in general and specifically for those with skills and training in energy efficiency solutions. Our interviews with building and construction contractor and trades association contacts suggest that members of these associations are somewhat resistant to training. Hiring is not a problem, as many people believe they can do construction work, and it is easy for employers to find entry-level workers. However, finding, hiring, training, and retaining skilled labor are more difficult, especially in less unionized areas with limited apprenticeship programs. The current approach used by employers in the building and construction industry is largely onthe-job training (as it is with all of the EESS), in part because of: 1) the resistance to training, 2) there are a limited number of qualified trainers, and 3)few younger people decide to take the additional training to become trainers themselves. Industry members attribute this to a combination of the aversion to work that entails manual labor and general lack of awareness of what building and construction work entail.

The building and construction contractor and trades associations have developed training and education programs for energy efficiency, but the number of certified members typically is less 
than $10 \%$ of their membership. Over $35 \%$ of the members of the associations are over 50 in the 11 states that were surveyed. Coupled with low interest in training, and to some extent, a limited interest in workers seeing building and construction contracting or trades as a long-term career, retirement appears to be a looming issue for the building and construction industry.

\subsubsection{Engineers and Managers}

According to program administrator, contractor, and ESCO respondents, the hardest positions to fill are experienced energy engineers and mid-level experienced managers. While retirement is not considered an issue for any of these types of firms, there is a bi-modal distribution in the age of workers in these firms. The result of this situation is that there are limited numbers of staff with 5-15 years' experience -- just the types of workers who would be seeking promotions to management and supervisory positions.

The need for these experienced staff is very serious, as these people provide the training and mentoring needed for on-the-job training, which dominates the EESS. Moreover, shortages of experienced energy engineers and mid-level experienced managers often create bottlenecks that limit growth in the broader EESS. Program administrators, program implementation contractors, and program support contractors have no difficulty hiring entry-level and staff with just a few years of experience, but someone has to manage these workers and professionals and ensure that the programs and projects are well-designed and -implemented.

Finding energy engineers, even at entry-level positions, is difficult for the EESS. There are very few energy-specific engineering degrees offered, there is no recognition of energy efficiency as a discipline in occupational and census data on engineering and the types of engineers sought by the EESS (engineers with good foundation in thermodynamics and fluid dynamics with good communication skills to talk to end users) are among the most highly valued in the engineering field.

Addressing the need for experienced managers will be difficult, but seeking managers from other fields and developing training to help them understand the field of energy efficiency could be effective. Another key approach for addressing the need for energy engineers is to work with the BLS to ensure that emerging EESS occupational categories are included in occupational handbooks and BLS economic census data.

\subsection{Staying the Course and Getting the Word Out}

It is critical for workforce development that public policies sustain a long-term commitment to energy efficiency. For example, the insulation industry comprises over 50\% of the current EESS workforce estimate, reflecting the impact of sustained and widespread building energy codes. Similarly, it is possible that spending and investment in ratepayer-funded energy efficiency may be more predictable in the future, particularly among those $~ 15$ states that have adopted legislation that establishes long-term commitments to energy efficiency (e.g. Energy Efficiency Resource Standards). 
At the root of the EESS workforce challenge is the fact the energy efficiency is not commonly understood in the population at large. A key challenge is to increase the visibility of energy efficiency. This means highlighting the benefits to the U.S. economy of increased energy efficiency, characterizing the current and potential economic impacts of the EESS, and informing and educating workforce development and labor market professionals on the emerging jobs and occupations that are unique to the EESS as well as the requirements for re-training and professional development of existing occupations so that they can effectively provide energy efficiency services as part of their normal business activities. We urge readers to review a companion LBNL study on workforce training and educational needs, which includes recommendations to address gaps in the training and education of the current and projected EESS workforce (Goldman et al. 2010). 


\section{References}

Adams, R. 2008. "Weatherization Assistance Program Economic Stimulus Expansion Paper." http://www.waptac.org/si.asp?id=1244. Weatherization Assistance Program Technical Assistance Center.

Alliance to Save Energy. "Stimulus Guidance Summary: State Energy Program (SEP).” http://ase.org/content/article/detail/5488. Washington DC.

Apollo Alliance 2007. “Community Jobs in the Green Economy.” Apollo Alliance: Urban Habitat. http://www.apolloalliance.org/ downloads/resources_Community_Jobs_in_the_Green_Economy.pdf. Oakland, CA.

Association of Energy Engineers 2009a. “Energy Independence and Market Trends: AEE Survey of the Energy Industry 2009.” http://www.aeecenter.org/shows/PDFs/2009EnergySurvey.pdf. Atlanta, GA.

Association of Energy Engineers 2009b. "Green Jobs: Survey of the Energy Industry.” http://www.aeecenter.org/shows/PDFs/SurveyofTheGreenEnergyIndustry.pdf. Atlanta, GA.

Bell, S 1982. "Recent Science and Engineering Graduates Working in Energy Related Activities, 1979 and 1980.” Oak Ridge Associated Universities. Washington DC, Department of Energy.

Barbose, G., C. Goldman, and J. Schlegel, 2009. “The Shifting Landscape of Ratepayer-Funded Energy Efficiency in the U.S.” The Electricity Journal, LBNL-2258E. October. http://eande.lbl.gov/EA/EMP/reports/lbnl-2258e.pdf

Bezdek, R. 2007. "Renewable Energy and Energy Efficiency: Economic Drivers for the 21st Century”. Boulder, CO. American Solar Energy Society.

Brown, C., and Greg Linden 2008. "Is there a Shortage of Engineering Talent in the U.S.” Institute for Research and Labor Employment. University of California, Berkeley.

California Employment Development Department Green Jobs Website 2009. “Green Economy Initiatives - State of California.”

http://www.labormarketinfo.edd.ca.gov/article.asp?ArticleId=1208\&SubId=\&PageId=\& Visited=true.

California Public Utilities Commission 2008. "California Statewide Long Term Energy Efficiency Strategic Plan.” San Francisco, CA.

Center for Defense Information 2007. “CDI’s 2007 Military Almanac.” http://www.cdi.org/program/document.cfm? DocumentID=4102\&from_page=../index.cfm. Washington D.C. The Center for Defense Information. 
Centers of Excellence 2009a. "Energy Efficiency Occupations in the Bay Region.” http://www.coeccc.net/Environmental_Scans/ee_scan_sf-gsv_09.pdf. San Francisco, CA

Centers of Excellence 2009b. "Energy Efficiency Occupations: Central Region.” http://www.coeccc.net/Environmental_Scans/ee_scan_cv_09.pdf. Modesto, CA.

Centers of Excellence 2009c. "Energy Efficiency Occupations: Greater Sacramento Region.” http://www.coeccc.net/Environmental_Scans/ee_scan_gs_09.pdf. Sacramento, CA.

Centers of Excellence 2009d. "Energy Efficiency Occupations: Inland Empire Region.” http://www.coeccc.net/Environmental_Scans/ee_scan_ie_09.pdf. San Bernardino, CA.

Centers of Excellence 2009e. "Energy Efficiency Occupations: Los Angeles Region.” http://www.coeccc.net/Environmental_Scans/ee_scan_la_09.pdf. Los Angeles, CA.

Centers of Excellence 2009f. "Energy Efficiency Occupations: Northern Coastal Region.” http://www.coeccc.net/Environmental_Scans/ee_scan_noCoast_09.pdf. Sacramento, CA.

Centers of Excellence 2009g. "Energy Efficiency Occupations: Northern Inland Region.” http://www.coeccc.net/Environmental_Scans/ee_scan_norIn_09.pdf. Sacramento, CA.

Centers of Excellence 2009h. "Energy Efficiency Occupations: San Diego and Imperial Region." http://www.coeccc.net/Environmental_Scans/ee_scan_sdi_09.pdf. El Cajon, CA.

Centers of Excellence 2009i. "Energy Efficiency Occupations: South Central Region.” http://www.coeccc.net/Environmental_Scans/ee_scan_socen_09.pdf. Ventura, CA.

Cleaner, Greener, and Smarter Act, S. 5, $111^{\text {th }}$ Congress, $1^{\text {st }}$ Session (2009).

Connecticut Clean Energy Fund (CCEF) 2009. “Connecticut Renewable Energy/Energy Efficiency Economy Baseline Study: Phase 1 Deliverable.” Navigant Consulting. Burlington, MA.

Consortium for Energy Efficiency 2007a. "Energy Efficiency Programs." http://www.cee1.org/ee-pe/2007/tables/Table1.pdf. Boston, MA.

Consortium for Energy Efficiency 2007b. "Energy Efficiency Programs: A \$3.7 Billion U.S. and Canadian Industry.” http://www.cee1.org/ee-pe/2007/2007EEPReport.pdf., Boston, MA.

Consortium for Energy Efficiency 2008. “Annual Industry Report.” http://www.cee1.org/eepe/2008/us_combo.php. Boston, MA.

Dafoe, J. 2007. “Growing Green Collar Jobs: A Report by Urban Agenda for the NYC Apollo Alliance.” http://www.urbanagenda.org/pdf0607/GGCJenergyefficiency5.pdf. New York, NY. Urban Agenda. 
Department of Energy Industrial Technologies Program (ITP): Key Partnerships in Response to Critical Workforce Needs 2008. Memo about how Johnson Controls, Inc. can directly support energy engineering students at Industrial Assessment Centers.

Eldridge, M., M. Neubauer, D. York, S. Vaidyanathan, A. Chittum, S. Nadel 2008. “The 2008 State Energy Efficiency Scorecard.” Report E086. Washington, DC. American Council for an Energy Efficient Economy.

Energy Information Administration 2005. “Table 11.3 World Primary Energy Consumption by Region 1996-2005.” http://www.eia.doe.gov/emeu/aer/txt/ptb1103.html, Washington DC.

Energy Information Administration 2007a. “International Energy Annual 2005.” Table E1. http://www.eia.doe.gov/emeu/aer/txt/stb1103.xls. Washington DC.

Energy Information Administration 2007b. “Annual Energy Review, U.S. Primary Energy Consumption by Source and Sector, 2007.” http://www.eia.doe.gov/emeu/aer/pecss_diagram.html on April, 8, 2009. Washington DC.

Energy Information Administration 2008a. “Annual Energy Review.” http://www.eia.doe.gov/oiaf/archive/aeo08/index.html. Washington DC.

Energy Information Administration 2008b. “Greenhouse Gases, Climate Change, and Energy.” http://www.eia.doe.gov/bookshelf/brochures/greenhouse/Chapter1.htm. Washington DC.

Energy Information Administration 2008c. "Short Term Energy Outlook.” http://www.eia.doe.gov/steo. Washington DC.

Energy Information Administration 2008d. “Annual Energy Outlook 2008: Reference Case, GDP Chain-type Price Index.” DOE/EIA-0383(2008).. http://www.eia.doe.gov/oiaf/archive/aeo08/index.html. Washington D.C.

Energy Information Administration 2009a. “Electric Power Annual 2007.” http://www.eia.doe.gov/cneaf/electricity/epa/epa_sum.html. Washington DC.

Energy Information Administration 2009b. “Table 8.13 Electric Utility Demand Side Management Programs 1989-2007.” http://www.eia.doe.gov/emeu/aer/txt/ptb0813.html 12/4/09. Washington DC.

Erhardt-Martinez, K. and Laitner, S. 2008. “The Size of the U.S. Energy Efficiency Market. Report No. E083.” Washington DC: American Council for an Energy-Efficient Economy.

Eto, J., R. Prahl and J. Schlegel. 1996. “A Scoping Study on Energy Efficiency Market Transformation by California Utility DSM Programs. Berkeley, CA: Lawrence Berkeley National Laboratory. 
Federal Energy Regulatory Commission (FERC) 2008. “Increasing Costs in Electric Markets, Item No.: A-3,” http://www.ferc.gov/legal/staff-reports/06-19-08-cost-electric.pdf. Washington DC, Department of Energy.

Garfield, B. (Interviewer) \& P. Angelides. (Interviewee) 2008. "Word Watch: Green Collar.” http://www.onthemedia.org/transcripts/2008/05/16/06 Washington DC: National Public Radio.

Goldman, C., N. Hopper, and J.G. Osborn 2005. "Review of U.S. ESCO industry market trends: an empirical analysis of project data,” Energy Policy, 33(3), 387-405, LBNL-52320, February.

Goldman, C., J. S. Peters, N. Alber, E. Stuart, and M. Fuller 2010. “Energy Efficiency Services Sector: Workforce Education and Training Needs,” Lawrence Berkeley National Laboratory, LBNL-3163E, March.

Hendricks, B., et al. 2009. "Seven Questions About Green Jobs: Why the most productive jobs of the future will be green jobs.” Center for American Progress. http://www.americanprogress.org/issues/2009/04/pdf/green_jobs_questions.pdf

Hopper, N., C. Goldman, D. Gilligan, T. Singer, and D. Birr 2007. “A Survey of the U.S. ESCO Industry: Market Growth and Development from 2000-2006.” Berkeley, CA: Lawrence Berkeley National Laboratory, LBNL-62679.

Kammen, D. M., and S. Pacca 2004. “Assessing the Costs of Electricity.” Annual Review of Environmental Resources. Annual Reviews. 29:301-44.

Larsen, P., C. Goldman, and A. Satchwell 2010. “Analysis of U.S. ESCO Public and Private Sector Projects: 1990-2008.” Berkeley, CA: Lawrence Berkeley National Laboratory, forthcoming.

Leon, M. 2005. "The Future of Scientists and the Engineers in the Defense Industry: A Presentation to the American Institute of Aeronautics and Astronautics.”

McKane, A., R. Williams, W. Meffert, M. Matteini 2009. "Industrial Energy Efficiency As Standard Practice,” http://industrial-energy.lbl.gov/node/443

McKane, A., P. Scheihing, R. Williams 2007. “Certifying Industrial Energy Efficiency Performance: Aligning Management, Measurement, and Practice to Create Market Value.” Proceedings of the 2007 Summer Study on Industry. Washington, DC: American Council for an Energy-Efficient Economy.

McKane, A., D. Desai, W.A. Meffert, H. Grell-Lewe 2008. "Summary Comparison of National Energy Management Standards.” Berkeley, CA: Lawrence Berkeley National Laboratory. http://industrial-energy.lbl.gov/files/industrialenergy/active/0/UNIDO\%20sac\%20summary\%20of\%20standards\%20comparative\%20a nalysis.pdf 
Morris, A.P., W. Bogart, A. Dorchak, R. Meiners 2009. “Green Jobs Myths.” University of Illinois Law and Economics Research Paper Series No. LE09-001 Champaign, IL. pp. 96.

Nadel, S. “The Changing Face of Energy Efficiency and Market Transformation.” Washington D.C. American Council for an Energy-Efficient Economy.

NASCSP: National Association for State Community Services Programs 2008. "Weatherization Assistance Program PY 2007 Funding Survey.” http://www.waptac.org/si.asp?id=1198. Weatherization Assistance Program Technical Assistance Center.

NASCSP: National Association for State Community Services Programs 2008. "Legislative Summary - WAP, February 2009.” www.waptac.org/si.asp?id=1275 . Weatherization Assistance Program Technical Assistance Center.

National Science Foundation, Division of Science Resources Statistics 2008. "Science and Engineering Degrees: 1966-2006.” Detailed Statistical Tables NSF 08-321. Arlington, VA. Available at http://www.nsf.gov/statistics/nsf08321/.

New England Clean Energy Council 2009a. “Green Jobs \& Energy Market Trends Relevant Trends, Opportunities, Projections \& Resources.” Presented by the Association of Energy Engineers. Atlanta GA.

New England Clean Energy Council 2009b. "Workforce Impacts of Expanded Utility Commercial and Industrial Energy Efficiency Funds in Massachusetts.” Prepared by the Peregrine Energy Group. Boston, MA.

Northwest Energy Efficiency Council 2008. "Workforce Development Needs of the Energy Efficiency Industry Survey Results from Washington and Oregon.” Seattle, WA.

Northwest Power and Conservation Council 2009a. "Northwest Energy Efficiency TaskForce: Workgroup \#5: Workforce of the Future,” May. http://www.nwcouncil.org/energy/neet/Default.asp

Northwest Power and Conservation Council 2009. “Accelerating Energy Efficiency to Reduce the PNW Power System's Carbon Footprint.” http://www.affordablecomfort.org/event/aci_northwest_conference_2009/handouts. Affordable Comfort Northwest Conference, February 3.

Opalka, W. 2008. The Next Generation. EnergyBiz: An Energy Central Publication, 45-48, MayJune.

Oregon Employment Department 2008. “Oregon’s Energy Efficiency and Renewable Energy Workforce.” Labor Market Information. Worksource Oregon - Employment Department.

Pacala, S. and R. Socolow. 2004. "Stabilization Wedges: Solving the Climate Problem for the Next 50 Years with Current Technologies,” Science, 13 August 2004, Vol. 305. 
Peters, J. and M. McRae 2008. Free Ridership Measurement is Out of Sync with Program Logic... or, We've Got the Structure Built, but What's Its Foundation? Proceedings of the 2008 ACEEE Summer Study on Energy Efficiency in Buildings. American Council for an Energy Efficiency Economy. Washington, D.C. August.

Peters, J. and M. McRae 2009. “Process Evaluation Insights on Program Implementation.” Oakland, CA. California Institute for Energy and Environment.

Prelas, M. 2008. “Wanted: Nuclear Engineers. Staffing the Future Fleet.” Energy Biz. p 46-48. May/June 2008.

Public Service Enterprise Group (PSE\&G) Media Releases 2008. "Combating the Utility Workforce Perfect Storm.” June 27. http://www.pseg.com/media_center/pressreleases/articles/2008/2008-06-27.jsp.

Pollin, R., H Garrett-Peltier, J. Heintz, H. Scharber 2008. “Green Recovery: A Program to Create Good Jobs and Start Building a Low Carbon Economy.” Political Economy Research Institute, University of Massachusetts - Amherst and Center for American Progress. Amherst MA. pp. 42.

\section{ADD ELIZABETH REDMAN REFERENCE}

Satchwell, A., C. Goldman, P. Larsen, D. Gilligan, and T. Singer 2010. “A Survey of the U.S. ESCO Industry: Market Growth and Development from 2008 to 2011.” Lawrence Berkeley National Laboratory: LBNL-3479E, Berkeley, CA, June.

Save American Energy Act, HR 889, $111^{\text {th }}$ Congress, $1^{\text {st }}$ Session (2009).

Schipper, Lee and S. Meyers 1992. Energy Efficiency and Human Activity: Past Trends, Future Prospects. New York: Cambridge University Press.

Socolow, R. and Pacala, S. 2004. "Stabilization Wedges: Solving the Climate Problems for the Next 50 Years with Current Technologies.” Science,Vol 305 no 5686 pp. 968-972.

Stern, G. 2007. “Help Wanted: New Workforce Programs Aim to Fill Vacancies.” EnergyBiz: An Energy Central Publication, 10-12. September/October.

Takahashi, K. and D. Nichols 2008. “The Sustainability and Costs of Increasing Efficiency Impacts: Evidence from Experience to Date.” 2008 ACEEE Summer Study on Energy Efficiency in Buildings.

The United States Conference of Mayors and Mayors Climate Protection Center 2008. "Current and Potential Jobs in the U.S. Economy.” Prepared by Global Insight. Washington DC: U.S. Conference of Mayors.

United Nations Expert Group on Energy Efficiency 2007. "Realizing the Potential of Energy Efficiency: Targets, Policies, and Measures for G8 Countries.” Washington DC.: United Nations Foundation. 
U.S. Census Bureau 2009. "State and County Quickfacts. State Population for CA, WA, TX, IL, IA, WI, MD, NJ, NY, CT, MA.” http://quickfacts.census.gov.

U.S. Department of Energy, Energy Efficiency and Renewable Energy 2009a. "Weatherization Program Notice.” http://www.waptac.org/si.asp?id=1341. Washington DC:

Weatherization Assistance Program Technical Assistance Center, U.S. DOE.

U.S. Department of Energy, Energy Efficiency and Renewable Energy 2009b. “2009 Recovery Act and Weatherization Funding."

http://apps1.eere.energy.gov/weatherization/recovery_act.cfm. Washington DC: Weatherization Assistance Program, U.S. DOE.

U.S. Department of Energy, Energy Efficiency and Renewable Energy 2009. “Weatherization Assistance Program.” http://apps1.eere.energy.gov/weatherization/improving.cfm. Washington D.C.

U.S. Department of Energy 2007. "State and Regional Polices that Promote Energy Efficiency Programs Carried out by Electric and Gas Utilities” A Report to the United Stated Congress Pursuant of Section 139 of the Energy Policy Act of 2005.” http://www.oe.energy.gov/DocumentsandMedia/DOE_EPAct_Sec.1139_Rpt_to_Congres sFINAL_PUBLIC_RELEASE_VERSION.pdf. Washington D.C.: U.S. Department of Energy.

U.S. Department of Labor 2007. “2006-16 National Employment Matrix, detailed by Occupation.” http://www.bls.gov/emp/empiols.htm., Washington D.C.: U.S. Department of Labor, Bureau of Labor Statistics.

U.S. Department of Labor 2009. “Occupational Handbook.” http://www.bls.gov/OCO/. Washington DC: U.S. Department of Labor, Bureau of Labor Statistics.

U.S. Department of Labor 2010. “O*Net Resource Center.” http://www.onetcenter.org/. Washington DC.: U.S. Department of Labor Employment and Training Administration. 